Canadian

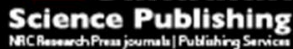

Canadian Geotechnical Journal Revue canadienne de géotechnique

\title{
The Influence of Water and Lubricant Fluids on The Peak Strength of Queenston Shale from Southern Ontario
}

\begin{tabular}{|r|l|}
\hline Journal: & Canadian Geotechnical Journal \\
\hline Manuscript ID & cgj-2016-0238.R2 \\
\hline Danuscript Type: & Article \\
\hline Complete List of Authors: & $\begin{array}{l}\text { Al-Maamori, Hayder Mohammed Salim; WESTERN UNIVERSITY, CIVIL AND } \\
\text { ENVIRONMENTAL ENGINEERING } \\
\text { EI Naggar, M. Hesham; University of Western Ontario, } \\
\text { Micic, S.; Geotechnical Research Centre, } \\
\text { Lo, Kwan; Geotechnical Research Centre, ; Geotechnical Research Centre, }\end{array}$ \\
\hline Keyword: & $\begin{array}{l}\text { Queenston shale, peak strength, micro-tunnelling, lubricant fluids, soaking } \\
\text { effects }\end{array}$ \\
\hline & \\
\hline
\end{tabular}

SCHOLARONE ${ }^{m}$

Manuscripts 


\section{i) Title: The Influence of Water and Lubricant Fluids on The Peak Strength of Queenston Shale from Southern Ontario}

\section{ii) Authors:}

1- Hayder Mohammed Salim Al-Maamori

$\mathrm{PhD}$, Research Assistant, civil and environmental engineering department, western university..... spencer engineering building, room 1041-f, western university, London, Ontario, Canada, N6A 3K7, Tel: +1 519661 2111-ext.88290, Email: halmaamo@uwo.ca

2- Mohamed Hesham El Naggar, P.Eng. professor, civil and environmental engineering department, western university..... spencer engineering building, room 2080, western university, London, Ontario, Canada, N6A 3K7, Tel: +1 519661 4219, Email: helnaggar@eng.uwo.ca

3- Silvana Micic, P.Eng. adjunct professor, geotechnical research centre, western university.... spencer engineering building, room 3095, western university. London, Ontario, Canada, N6A 3K7, Tel: +1 519 6612111-ext.87242,Email: smicic2@uwo.ca

4- K.Y. Lo, P. Eng.

Professor Emeritus, Director- Geotechnical Research Centre, Western University..... Spencer Engineering Building, room 3080, Western University, London, Ontario, Canada, N6A 3K7, Tel: +1 519661 2125, Email: cquintus@eng.uwo.ca 


\section{iii) Corresponding author:}

Hayder Mohammed Salim Al-Maamori

PhD Research Assistant, Civil and Environmental Engineering Department, Western

University.... international and graduate affairs building, room 3N38, Western University,

London, Ontario, Canada, N6A 3K7, Tel: +1 519671 8468, Email: halmaamo@uwo.ca 


\begin{abstract}
The strength of Milton Queenston Shale (MQS) ${ }^{1}$ before and after soaking in water and lubricant fluids (LFs) ${ }^{2}$ was examined. The investigated LFs (i.e. bentonite and polymer solutions) are utilized in micro-tunnelling technique $(\mathrm{MTT})^{3}$ to facilitate the installation of tunnel or pipe sections. To investigate the relevant mechanical properties of MQS under different wetting conditions, a series of laboratory tests including Brazilian split, uniaxial compression, and triaxial compression were carried out. These tests were performed on vertically and horizontally cored specimens with respect to the rock bedding. Fresh specimens (i.e. intact), and specimens soaked for 100 days in LFs and in water were examined. The 100 days period was selected as it may reasonably represent the construction period where some swelling of the Queenston Shale can occur. It was revealed that the strength of MQS substantially decreased after soaking. With greater impact in vertical direction, both water and bentonite solution caused similar decrease in MQS strength of $23-70 \%$, while polymer solution caused a smaller decrease of $10-57 \%$.

Accordingly, strength envelopes of MQS were established for vertical and horizontal directions before and after soaking.
\end{abstract}

Key Words: Queenston Shale, peak strength, micro-tunnelling, lubricant fluids, soaking effects.

\footnotetext{
${ }^{1}$ MQS: Milton Queenston Shale

${ }^{2}$ LFs: Lubricant Fluids (i.e. bentonite solution, and polymer solution)

${ }^{3}$ MTT: Micro Tunnelling Technique
} 


\section{Introduction}

Micro-tunnelling is an effective construction technique to install pipelines and tunnels of variable diameters in several types of soil. However, adopting micro-tunneling technique (MTT) to install pipelines and tunnels in weak rocks, such as the Queenston Shale of Southern Ontario, is still ambiguous and needs to be investigated. Lubricant fluids (LFs), such as bentonite and polymer solutions, are used in MTT during the installation of the pipe or tunnel sections. This process may last for several weeks where the excavated rock is in direct contact with LFs. Based on the recognized swelling behaviour of the Queenston Shale, when it contacts water, and the associated development of micro-cracks (Lee and Lo 1993), it is suggested here to investigate the strength of Milton Queenston Shale (MQS) when exposed to water and LFs.

Previous studies on the strength behaviour of sedimentary rocks have focused primarily on the following aspects, for example: strength anisotropy (Dan et al. 2013; Claesson and Bohloli 2002; and Lo and Hori 1979), Brazilian and direct tension strength test relationship (Perras and Diederichs 2014; Li and Wong 2013; Gorski et al. 2007), strength-volume relationship (Lee 1988; Lo et al. 1987), strength-temperature relationship (Vishal et al. 2011; Wai et al. 1981; and Closmann and Bradley 1979), post peak failure behaviour, and the influence of brine and water on the strength (Wasantha and Ranjith 2014; Liang et al. 2012; Paterson and Wong 2005; Baud et al. 2000; Paterson 1978; Colback and Wiid 1965). Dan et al. (2013), and Lo and Hori (1979) investigated the strength anisotropy of sedimentary rocks by employing the Brazilian split, unconfined compression and triaxial compression tests. They concluded that sedimentary rocks generally exhibit anisotropic strength behaviour, which is highly dependent on the direction of applied stress with respect to the rock beddings. Perras and Diederichs (2014) reviewed the tensile strength of different rocks measured from the Brazilian split test and the direct tension 
test. They concluded that the tensile strength of sedimentary rocks measured from the direct tension test is $70 \%$ of its value measured from the Brazilian split test, and the difference depends on the rock type and it may require further investigation. The Brazilian test is found to usually overestimate the tensile strength of rocks (Li and Wong 2013). Gorski et al. (2007) found that the tensile strength of the granite from Forsmark, Sweden, measured in direct tension test was 39$69 \%$ of its tensile strength measured in Brazilian split test. Claesson and Bohloli 2002 suggested a formula to calculate the principal tensile strength at centre of disc in Brazilian split test in anisotropic rocks. Lee (1988) proposed a stress-strain relationship for the Queenston Shale using results of the Brazilian split and uniaxial compression tests. Lo et al. (1987) studied the effect of specimen's size on the strength and concluded that the deformation modulus of shaly limestone decreases with increasing the size of specimen, approaching the mass modulus. In general, heating was found to cause various decrease in the rock strength, depending mainly on the type of the tested rock and the way of measuring its strength (Vishal et al. 2011; Wai et al. 1981; Closmann and Bradley 1979). Wasantha and Ranjith (2014), and Liang et al. (2012) studied the decrease in strength of gypsum and Hawkesbury sandstone due to saturation in water and brine leaching, and reported that a considerable amount of the strength of both rocks was lost. Paterson and Wong (2005), Baud et al. (2000), Paterson (1978), and Colback and Wiid (1965) attributed weakening effects of water on the strength of rocks to the pressurized pore water that decreases the effective strength and weakens the rock structure.

It can be noted from the above that earlier research have covered many factors that can influence the strength of rocks at their natural condition. However, there is a gap in the literature of the effect of time-dependent deformations of swelling shales, such as the Queenston shale, on their strength when they are exposed to water and lubricant fluids for a considerable period. Upon this 
exposure, some of the time-dependent deformations can occur, which in turn may influence the strength of this shale.

\section{Work Objective and Scope}

Although many studies investigated water effects on the strength of several types of rocks from various locations of the world, the region of southern Ontario is still lacking in this aspect. Of particular interest, the influence of lubricant fluids used in micro-tunneling technique, such as bentonite and polymer solutions, on the strength of the Queenston shale need to be investigated thoroughly. The Queenston shale covers vast majority of the metropolitan area of southern Ontario cities and forms the hosting ground for many micro-tunneling projects. Results of such investigation can be of high significance for micro-tunneling applications, as this technique is quite new in shales of this region. The work reported herein is part of a comprehensive study to investigate the feasibility of the micro-tunneling technique in shales of southern Ontario. The presented work aims to investigate the influence of soaking in water and LFs used in MTT on the strength of MQS. Specimens were cut parallel and perpendicular to the rock bedding to investigate strength anisotropy of MQS before and after soaking. Vertical and horizontal specimens of MQS were kept submerged in water and LFs for 100 days. This period may represent the construction period, where the gap between the aperture drilled by the microtunneling machine and the installed pipeline or tunnel, will be continuously filled with the lubricant fluid before replacing it with the permanent cement grout. A total of 103 specimens were tested: 35 specimens in Brazilian split test, 25 specimens in unconfined compression test, 40 specimens in triaxial compression test, and three specimens in direct tension test, before and after soaking. The changes occurred in MQS strength due to soaking effects are presented and 
discussed. The measured strength was utilized to develop strength envelopes of MQS before and after soaking in water and LFs in both parallel and perpendicular directions to the rock bedding. The developed strength envelopes of MQS after soaking can give an insight of the amount of strength that can be lost due to soaking in water and LFs.

\section{Borehole}

Samples were collected from a single vertical borehole drilled near the interchange between Regional Road 25 and Louis St. Laurent Avenue in Milton, Ontario. The borehole was located $150 \mathrm{~m}$ to the east of the interchange, and $10 \mathrm{~m}$ to the south of Regional Road 25. The recovered MQS samples were collected from depth of 15.50 to $34.50 \mathrm{~m}$ below the ground level (BGL) ${ }^{4}$. Thirteen runs of recovered rock columns were collected in two days. Immediately after coring, samples were identified and wrapped with saran wrap followed with electrical tape, and bubble wrap to preserve the moister. Wrapped samples were placed inside hard polyvinyl chloride (PVC) pipes with two rubber end caps for each rock piece followed by a mechanical clamping to protect samples during transporting to the laboratory at Western University.

The collected samples were Queenston Shale interbedded with thin layers of shaly limestone. The rock quality designation (RQD) $)^{5}$ value varied between $50.0 \%$ and $99.2 \%$, indicating rock condition varying from fair to good to excellent with increasing depth as indicated in Fig. 1. The borehole logging indicated that the Queenston Shale layer has occasionally 2-4 mm thick gypsum nodulus that exist along the entire layer at average intervals of $1.0 \mathrm{~m}-1.4 \mathrm{~m}$. Based on the recurrence of joints, and RQD value of each run, the Queenston Shale layer can be divided

\footnotetext{
${ }^{4}$ BGL: Below the ground level

${ }^{5}$ RQD: Rock quality designation
} 
into three sub-layers: a) top layer from depth of $15.5 \mathrm{~m}$ to $22.5 \mathrm{~m}$ BGL, with an average RQD value of $68.9 \%$, and majority of $2 \mathrm{~mm}-5 \mathrm{~mm}$ of compacted clay joints that occur at an average of 4 joints/m, b) intermediate layer from $22.5 \mathrm{~m}$ to $26.5 \mathrm{~m}$ BGL with an average RQD value of $89.9 \%$, and $2 \mathrm{~mm}-5 \mathrm{~mm}$ compacted clay joints that occur at an average of 1 joint $/ \mathrm{m}$, and c) lower layer from $26.5 \mathrm{~m}$ to $34.52 \mathrm{~m} \mathrm{BGL}$ with average RQD value of $96.8 \%$, and joints of compacted clay occurring at 1 joint $/ 4 \mathrm{~m}$.

\section{Mineralogical composition of MQS}

The XRD analyses were performed on MQS specimens collected from four different depths to cover the entire rock column. Bragg's law was utilized in these analyses. The procedure of preparing test specimen and performing analyses is beyond the scope of this paper. Further details of sample preparations of the bulk and clay-size portion, and the calculation procedure of the semi-quantitative XRD analyses can be found in (Zhang et al. 2003; Moore and Reynolds 1989; Hein and Longstaffe 1983). The analyses revealed that MQS composed of the following minerals: 0.8-1.1\% Chlorite, 10.4-16.8\% Illite, 1.1-2.4 Kaolinite, 43.1-47.4\% Quartz, 3.3-6.7\% Feldspar, 19.3-28.2\% Calcite, 3.9-9.2\% Dolomite, and 2.2-3.7\% Pyrite. It can be noted that no significant swelling clay minerals exist in MQS, where both illite and kaolinite have low swelling capacity. Other minerals that can be affected by the presence of water, such as gypsum or anhydrite do not exist as well. To minimize the natural heterogeneity of specimens prepared for the strength tests, the gypsum nodulus were intentionally avoided. The swelling capacity of the pyrite can cause volumetric changes in shales. However, its effect on swelling of MQS can be limited due to its low presence. This can indicate that the influence of water and LFs on MQS can be expected to be similar to the well-recognized swelling mechanism of shales in southern 
Ontario. The swelling in these shales was attributed to the following three reasons: $i$ the relief of initial in situ stresses, ii the accessibility of water, and iii salinity gradient between the rock pore fluid and the ambient fluid (Lee and Lo 1993). Al-Maamori et al. (2014) concluded that the diffusion of MQS pore fluid salinity can be affected by bentonite solution causing this shale to swell slightly more than its swelling in water. In the same study, the polymer solution was found to cause less swelling due to its both physical action on the surface of MQS and its influence in reducing the diffusion process of pore fluid salinity.

\section{Test methodology}

MTT utilizes LFs during the construction period of tunnels and pipelines to facilitate the installation of the tunnel or pipe sections. These fluids are used to reduce the frictional forces between the excavated ground and the tunnel or pipe sections, and hence reduce the required driving forces applied by the jacking system. Additional function of the LFs is to support the excavated ground to maintain tunnel stability. The installation period of a tunnel or a pipeline depends on how hard the ground is and the run distance between successive shafts. Adopting MTT to install tunnels or pipelines in rocks such as MQS may have to account for strength loosening or strength softening. As part of a comprehensive research program in Western University to study the feasibility of MTT in Queenston Shale of Southern Ontario, it was concluded that LFs that are utilized in MTT minimized the swelling of these Shales (Al-Maamori et al. 2015) but did not eliminate it completely. Motivated by this finding and the continuous exposure of Queenston Shale to LFs during the installation period of the tunnel or pipeline, this paper investigates the influence of LFs on the strength behaviour of MQS. 
One of the suggested procedures to mitigate the influence of the time-dependent deformation of Queenston Shale and other swelling rocks in Southern Ontario on underground structures is to delay the installation of the permanent structure until sufficient rock deformation has occurred, so that any further deformation after construction is within manageable limits (Lo et al. 1987). In MTT, the permanent structure (tunnel or pipeline sections) is installed simultaneously while the micro-tunnelling boring machine advances. The gap between the tunnel or pipeline and the excavated shale, which is continuously filled with LFs, is permanently filled with cement grout at the end of installation period. In MTT, to apply the mitigation procedure of the swelling effects suggested by Lo et al. (1987), the application of the permanent cement grout can be delayed until a sufficient amount of rock deformation has occurred.

The LFs, polymer solution and bentonite solution, used in this research are the same as those used in the field with the same mixing proportions. The polymer solution was prepared by adding $0.8 \%$ of liquid polymer concentrate type TK60 (anionic polyacrylamide suspension in a water-in-oil emulsion from Morrison Mud, Division of Mudtech Ltd.-UK) to tap water with a continuous high-speed mixing. Similarly, the bentonite solution was prepared by mixing $8 \%$ of dry powder sodium bentonite clay type (HYDRAUL-EZ from CETCO-USA) with tap water. A soaking period of 100 days was selected in this research to represent a reasonable period for time-dependent deformation of MQS before replacing LFs with permanent cement grout. Three tests were utilized to cover the full-strength envelope of MQS: Brazilian split test, unconfined compression test, and triaxial compression test with different confining pressure up to $20 \mathrm{MPa}$. In addition, to evaluate the strength anisotropy, the strength behaviour of MQS in the vertical and horizontal directions was investigated. Total of 35 Brazilian split tests, 25 unconfined compression tests, and 40 triaxial compression tests were performed on MQS 
samples. Tests were conducted on specimens that were cut and prepared as received from the field at their natural moisture content (denoted herein as intact specimens), and on specimens soaked for hundred days in LFs (i.e. polymer and bentonite solutions) and in water. All tests were performed on physically intact specimens (i.e. before and after soaking). Water was used as a control fluid where it is usually used as the ambient fluid to measure swelling deformation of rocks. Due to the limited supplied samples, only three direct tension tests were performed on intact vertical specimen to select the appropriate reduction on the Brazilian splitting strength and convert it to the corresponding direct tension strength. All tests were performed at room temperature. The tensile, unconfined compression and triaxial compression strength results were used to produce the strength envelops of MQS before and after soaking, in both vertical and horizontal directions.

Cutting test specimens and re-coring samples to get horizontal specimens was done at the laboratory of Western University using a diamond slab saw and a coring machine. Mineral oil (Pella type A from Shell Canada) was used as a cooling fluid during sample cutting to prevent any change in its moisture content. For each test specimen, additional tests were performed, such as: calcite content, moisture content, mass density, and pore water salinity. The Brazilian split test was performed according to the procedure described in ASTM-D3967 (2008). The unconfined compression test was conducted according to method " $C$ " and " $\mathrm{D}$ " described in ASTM-D7012 (2010) while the triaxial compression test was performed according to method “A" and "B" described in ASTM-D7012 (2010).

The ultimate tensile strength, the ultimate unconfined compression strength, and the ultimate compression strength were measured in both vertical and horizontal directions. The triaxial compression tests were performed under different confining pressure (i.e. 2.5 $\mathrm{MPa}, 5.0 \mathrm{MPa}, 7.5$ 
$\mathrm{MPa}$, 10.0 MPa, 15.0 MPa and 20.0 MPa). The high confining pressure represented the high insitu horizontal stresses that exist in Queenston Shale of Southern Ontario (Al-Maamori et al. 2014). The Poisson's ratio was calculated in these tests based on the vertical and horizontal deformation curves at the elastic deformation portion. The elastic modulus was also calculated using method "b" described in ASTM- D7012 (2010), and the shear modulus was accordingly calculated. The measured strength and the calculated parameters for intact MQS and soaked MQS in LFs and in water are presented and discussed in detail in the discussion section.

\section{Maintaining specimens during soaking period}

It is well recognized that Queenston Shale develops micro-cracks when submerged in water due to the increase in the volume of macropores and ultra-micropores (Lee and Lo 1993). These micro-cracks may develop along the entire small size specimen and hence renders maintaining specimen soundness quite difficult. A procedure was developed in this research to maintain the test specimens during the soaking period. After cutting the specimen, a layer of screen wire mesh was used to coat the entire specimen. Terminals of the coating screen wire mesh were sewed firmly together by hand using fish wire of 60-Pounds line. Many winding layers with the fish wire in the longitudinal direction of the specimen were added. This was followed by several transverse winding layers with the fish wire. This procedure allowed LFs and water to contact the specimen through the holes in the screen wire mesh, while maintaining the specimen intact. These steps are illustrated in Fig. 2.

\section{Modified high capacity triaxial cell}


Fig. 3 shows the high capacity triaxial cell used to perform the triaxial compression tests on MQS. The cell was designed earlier in Western University to investigate the strength parameters of concrete-rock contact at dam-foundation interface (Lo et al. 1991). The cell consists of: 1) cell body made of hardened steel, 2) cell base made of hardened steel and contains three channels connect the inner chamber of the cell to the outside through inlet/outlet opening, 3) central pedestal mounted on the cell base, 4) piston to apply the vertical stress, made of hardened steel, with spherically concave base, and contains a rubber washer and stopper, 5) ventilation valve located on top of the piston to remove entrapped air bubbles in the confining fluid, 6) inlet/outlet junction connected to the cell base, 7) one-way inlet valve connected to the base through inlet/outlet junction for adding the required confining pressure fluid through a hydraulic jack, 8) outlet adjusting valve, 9) outlet needle valve for adjusting the confining pressure, connected through the inlet/outlet junction to cell chamber, and 10) specimen's assembly cap with spherical convex head to ensure centric applied load. The cell was modified by designing additional mechanical pieces to accommodate rock specimens of variable sizes, to ensure centering the specimen on the cell pedestal, to adopt high confining pressure up to $20 \mathrm{MPa}$, and to adjust the confining pressure manually during the test, if needed. These additional pieces are:

1) Multi-step adjusting seat mounted on the base pedestal through a depression in its bottom, which ensures centric specimen placement on the pedestal to minimize load eccentricity. It has multiple circular steps on its top to accommodate specimen diameter of $63,49,39$, and $33 \mathrm{~mm}$. 2) Multi-step adjusting cap that is seated on top of the specimen's end cap through the multiple circular steps in its bottom. It has two circular steps on its top to accommodate the specimen's assembly cap (10). The cap ensures that the spherical specimen's assembly cap is centred atop the specimen during the test to minimize load eccentricity. 
3) Two platens placed directly at top and bottom of the specimen.

4) Pressure transducer, with 10,000 psi capacity (type AST4000A10000PAD0000, American Sensor Technology, NY) connected to the cell base to measure the confining pressure up to 68.9 MPa with an accuracy of $\pm 0.5 \%$.

5) Sealing gland with eight wires connection and Teflon sealant (type MCH4, Conax Technologies, Buffalo) connected to cell base to allow the wires of electronic strain gauges that are mounted on the rock specimen to pass through without oil leakage from the cell chamber. To avoid contact between bare connections of electronic strain gauges, dielectric transformer oil type MODEF60 from (Aevitas Inc., Brantford, ON) used as ambient fluid to apply the required confining pressure. The in-situ horizontal stress recorded in the Queenston shale layer of Niagara Falls (nearby similar formation) at a depth of $93.9 \mathrm{~m}-123.8 \mathrm{~m}$ was $14.3 \mathrm{MPa}-17.1 \mathrm{MPa}$ (AlMaamori et al. 2014). Therefore, the triaxial tests were performed under confining pressure ranging up to $20 \mathrm{MPa}$.

\section{Electronic strain gauges}

Electronic foil strain gauges of $10 \mathrm{~mm}$ length, type N11-FA-10-120-11, and terminals for foil strain gauges type FG-10T from (SHOWA Measuring Instruments Company Ltd., Tokyo, Japan) were used to measure the vertical and horizontal strains of the rock specimen during the unconfined compression test and the triaxial compression test. When the soaking period was completed, four electronic foil strain gauges were glued on each test specimen using instant adhesive glue type (Loctite 454 from Loctite Corporation North American Group, USA). The strain gauges were glued in T-shape arrangement on two opposite side of the specimen. Two strain gauges were glued parallel to the longitudinal axis of the specimen to measure the vertical 
strain. The other two circumferential strain gauges were glued on the circumference of the specimen perpendicular to its longitudinal axis to measure the horizontal strain.

\section{Triaxial compression test procedure}

To perform the triaxial compression test, the end caps were placed on top and bottom of the test specimen followed by $0.64 \mathrm{~mm}$ thick triaxial membrane with silicone and two O-rings to prevent the penetration of confining fluid into the rock specimen. The test specimen was placed on the multi-step adjusting seat that was mounted to the cell pedestal, and the multi-step adjusting cap was placed on top platen of the specimen followed by the specimen's assembly cap. Wires of strain gauges were connected to the wires of the sealing gland which in turn were connected to a computer data logger. Transformer oil was added to fill the cell chamber covering the whole specimen's assembly, and the cell piston is finally placed on top of the specimen's assembly spherical cap with the ventilation valve kept opened to allow for dissipating the entrapped air bubbles. When the piston was positioned in the cell, the ventilation valve was closed, and the cell was placed in the MTS machine to apply the vertical loading. A suitable vertical seating load $<1 \%$ of anticipated ultimate strength was applied on the specimen to ensure contact between all parts. The confining pressure was gradually added through a manual hydraulic jack while the readings of the pressure transducer were monitored. When the required confining pressure was reached, all valves were kept closed and the vertical loading was applied in a constant rate until specimen's failure was achieved. The load was applied according to the procedure described in ASTM-D7012 (2010) to achieve failure within 2-15 minutes. The confining pressure was kept constant during the test and any required adjustments were made through the outlet needle valve. 
All tests were successfully performed under the specified confining pressures using the modified triaxial cell without any leak of the ambient fluid.

\section{Results}

\section{Brazilian Split Test}

The Brazilian split test was performed on MQS specimens in both vertical and horizontal directions with respect to the rock beddings. Fig. 4 shows schematic details of the orientation of test specimens to measure the split strength in the vertical and horizontal directions. Vertically cored specimens were used to measure the split strength in the horizontal direction, while horizontally cored specimens were used to measure the split strength in the vertical direction. Cutting the test specimen was done in accordance with the ASTM-D4543 (2008), using mineral oil for cooling. Dimensions of the test specimens were kept within requirements of ASTMD3967 (2008) (i.e. thickness-to-diameter ratio between 0.2 and 0.75 ) and tests were performed according to the procedure given therein. Wooden plates were used to distribute the applied load evenly along the entire length of the specimen and to avoid localized forces. Total of 35 Brazilian tests were performed on MQS specimens: 12 in the horizontal direction and 23 in the vertical direction. The average value of minimum three successful tests was considered as the average splitting strength, as indicated in Table 1 and Table 2. For each test specimen, the moisture content and pore water salinity were measured before and after the soaking period, following ASTM-D2216 (2010) and the procedure described by Lee (1988), respectively. The Chittick carbon dioxide apparatus was utilized to determine the percentage of total carbonates content (i.e. calcite content and dolomite content) in each test specimen following the procedure 
described by Dreimanis (1962). These tests are considered supplementary to the strength tests performed on MQS.

The test results of the Brazilian split strength in the vertical and horizontal directions, and the corresponding supplementary test results are presented in Tables 1 and 2 . In these tables, the percentage decrease in the Brazilian split strength due to soaking effect in LFs and in water is also presented.

\section{Discussion}

The results presented in Tables 1 and 2 indicate that the split strength is anisotropic with respect to the rock bedding. In general, the Brazilian split strength was higher in the vertical direction than the Brazilian split strength in the horizontal direction. It can also be noted from Tables 1 and 2 that the Brazilian split strength of MQS has decreased significantly after soaking. However, the percentage decrease in the strength was not the same in vertical and horizontal directions, and depended on the ambient fluid. Soaking MQS in water caused 29\% and 57\% strength reduction in the vertical and horizontal directions, respectively, compared to the strength of intact specimens. Similarly, soaking MQS in bentonite solution caused 39\%, and 55\% strength reduction in the vertical and horizontal directions, respectively, compared to the strength of intact specimens. Whereas that soaking MQS specimens in polymer solution caused a strength decrease of only $10 \%$ and $34 \%$ in the vertical and horizontal directions, respectively, compared to their intact strength.

It is clear that the decrease in the strength of MQS due to soaking in water and LFs was more significant along the horizontal direction, which indicates that MQS is more susceptible to the influence of ambient fluids in the horizontal direction than in the vertical direction. This 
difference in the influence of ambient fluids can be attributed to the fabric of MQS particles. MQS has a considerably strong clayey fabric with the preferred orientation of horizontal layering, as indicated in the scanning electro microscopy (SEM) images presented in Fig. 5 (a) and (b). The SEM images were captured at vertical and horizontal sections of intact samples, and at the surface of MQS samples after soaking in polymer and bentonite solutions. The remarkable orientation of clayey fabric in the horizontal layering may cause a difference in the penetration of ambient fluids deep into MQS.

Ambient fluids may tend to penetrate deeper in the direction parallel to particles (i.e. horizontal direction) than in the perpendicular direction to the particles (i.e. vertical direction). This assumption can be true when dealing with the same fluid. However, with different fluids, such as those adopted in this research (i.e. water, polymer and bentonite solutions) the penetration can also be affected by the size of suspended particles in the fluid. Both polymer and bentonite solutions are composed of either polymer particles or bentonite particles suspended in water. When LFs contacts MQS, polymer (or bentonite) particles tend to accumulate on the outer surface of the shale creating coating layers, as indicated in Fig. 5 (c) and (d). However, the thickness of these coating layers is different. Polymer solution penetrates deeper into the surficial pores and surficial micro-cracks than bentonite solution. This behaviour makes the coating layer formed from polymer particles thicker than the coating layer formed from bentonite particles, as indicated in Fig. 5 (c) and (d). It seems that the polymer coating layer was relatively more efficient than bentonite coating layer in preventing excessive water particles from penetration deeper into MQS. 
The pore water salinity was measured before and after soaking MQS specimens in water and in LFs, and the test results together with the percentage decrease in the pore salinity are presented in Tables 1 and 2. The percentage decrease in the pore salinity of MQS due to soaking in bentonite solution was the highest (60-81\%) compared to water (55-77\%) and polymer solution $(28-41 \%)$. This means that the processes of diffusion and osmosis in MQS were more dominant in bentonite solution compared to water and polymer solution. The osmosis and diffusion processes are conditions for swelling of Queenston Shale of Southern Ontario to occur (Lee and Lo 1993). The coating layer on the outer surface of MQS and the effect of osmosis and diffusion could be the reasons that bentonite solution caused more decrease in the Brazilian split strength of MQS compared to water and polymer solution.

Fig. 6 shows the failure modes and cracks developed in MQS after reaching the split strength of both intact specimens and specimens soaked for 100 days in LFs and water. Photos in Figure 6 were captured from video records at failure. The failure of MQS in the vertical direction (i.e. in a direction perpendicular to the rock bedding) is assumed to be mainly generated along weak bonds between bedding planes, and the failure appears to have occurred simultaneously in multiple planes for the soaked specimens (Fig. 6: 1-b, 1-c, and 1-d). However, the vertical intact specimens failed mainly in a single crack developed along weak bonds between the rock bedding, as shown in (Fig. 6, 1-a). The Brazilian split failure of MQS in the vertical direction appears to be mainly pure tensile failure (i.e. straight cracks) in between bedding planes with some tensile-shear failures (i.e. curved cracks). Some wedges can also be noted, which may be attributed to the boundary effects of the loading platens and the wooden pads. On the other hand, failure of MQS in the horizontal direction (i.e. in the direction parallel to the rock bedding) developed in the form of tensile-shear failure with some wedges near the loading platens. During 
the test, the main failure cracks were noticed to develop first in the direction of the applied load. As the deformation increased with loading, more cracks developed in the direction perpendicular to the applied load. Splitting along bedding planes was also noticed in most of the soaked specimen followed by a complete collapse of the test specimens. The occurrence of splitting cracks prior to the occurrence of splitting between rock bedding in the horizontal specimens indicates that the tensile strength of MQS in the horizontal direction is smaller than the tensile strength in the vertical direction. This is quite consistent with the results presented in Table 1 and Table 2 .

Due to the biaxial state of stresses induced in the rock specimen in the Brazilian split test and its boundary effects, the measured tensile strength may overestimate the real tensile strength of the rock. In contrast, the direct tension test generates single state of tensile stress that acts on the rock specimen until it fails with minimal boundary effects influencing its result. Gorski et al. (2007) noted this difference when measured the tensile strength of the granite in both Brazilian split test and direct tension test. The tensile strength of the granite measured in direct tension test was $39-69 \%$, and averaging 54\% of its value measured in Brazilian split test. Perras and Diederichs (2014) performed a comprehensive review on the tensile strength of different rocks measured in the Brazilian split test and the direct tension test. They noted that the tensile strength of most tested rocks was higher in the Brazilian split test than its value measured in the direct tension test. This difference was the highest in sedimentary rocks, and their tensile strength measured in the direct tension test can be $70 \%$ of their tensile strength measured in the Brazilian split test. However, they indicated the need of further investigation on the tensile strength of other types of sedimentary rocks, where this difference can be greater. This observation was also reported for other materials, such as concrete (Neville 1996). The tensile strength of concrete 
measured in Brazilian split test was found to be higher than its value measured in direct tension test by $5-12 \%$. Based on these observations, it is more convenient to adopt the tensile strength of rocks measured in the direct tension test. However, this is not possible in our case, where it was quite difficult to do the sophisticated preparations for the test specimen of the direct tension test after soaking specimens for 100 days. Therefore, the tensile strength of MQS measured in Brazilian split test will be reduced by a $52 \%$ based on the direct tension test result performed on intact MQS, as it will be presented in a later section. The values of the equivalent tensile strength of MQS before and after soaking in water and in LFs are listed in Tables 1 and 2. These equivalent values of MQS tensile strength will be used to develop the strength envelopes of this shale.

\section{Direct tension test}

The direct tension test was performed on an intact vertical MQS specimens (i.e. non-soaked specimens) according to the ASTM-D2936 (2008), and following the procedure described in Lo et al (1991). The specimen was cut to a length/diameter ratio of 2. Care was taken to produce parallel contacts. Two end caps were glued on top and bottom of the specimen using two-part Epoxy resin and polyamide hardener adhesive from (Loctite and Hysol, Henkel Corporation, U.S.A.). The specimen was then mounted on MTS system through universal joints to eliminate load eccentricities. Tensile load was applied gradually on the specimen with a constant displacement rate of $0.024 \mathrm{~mm} / \mathrm{min}$ until failure. The tensile strength was calculated from dividing the failure load by the cross-sectional area of the specimen. Three direct tension tests were performed on intact vertical MQS samples. Due to the great difficulty to glue the steel end 
caps to the soaked rock specimens and connect them to the MTS system to apply the tensile loading, in addition to the high-risk of cracking rock specimens during soaking period, the direct tension test was only performed on intact MQS specimens (i.e. non-soaked specimens). The average tensile strength of MQS in the vertical direction was 4.5 MPa. This value represents $52 \%$ of the tensile strength of intact MQS measured in Brazilian split test in vertical direction (8.7 MPa), listed in Table 1. This percentage is very consistent with that reported by Gorski et al. (2007), and it is also close to the reduction value stated in (Perras and Diederichs 2014). Therefore, it is assumed here that this reduction percentage of $52 \%$ is valid in both vertical and horizontal MQS specimens, and it is adopted to calculate the equivalent direct tension strength of soaked specimens.

\section{Unconfined Compression Test}

The unconfined compression strength test was carried out on intact specimens and on specimens soaked for 100 days in LF and in water in both vertical and horizontal directions. Twenty-five unconfined compression tests were carried out, 12 on vertically oriented specimens, and 13 on horizontally oriented specimens. A constant rate of loading was applied until failure within 2-15 minutes according to the procedure described in methods "C" and "D" ASTM-D7012 (2010). Four electronic foil strain gauges were glued in T arrangement on two opposite sides of each test specimen to measure deformation strains along and perpendicular to the longitudinal axis of the test specimen, as illustrated in Fig. 3. For the horizontally oriented specimens, the strain gauges were glued on two orthogonal sides of the specimen: parallel to and across the rock bedding. With this arrangement, it was possible to measure two values of Poisson's ratio in the horizontal 
direction. The first value calculated from strain gauges on the side parallel to rock bedding is the Poisson's ratio for the effect of horizontal stress on horizontal strain, denoted as vh, while the second calculated value from strain gauges across the rock bedding is the Poisson's ratio for the effect of horizontal stress on vertical strain, denoted as vhv (Lo and Hori 1979).

The test results are presented in Tables 3 and 4 for vertically and horizontally oriented specimens, respectively. Typical results of the unconfined compression test performed on MQS are presented in Fig. 7 and Fig. 8 for vertically and horizontally oriented specimens, respectively.

\section{Discussion}

The results presented in Tables 3 and 4 indicate that MQS exhibited anisotropic behaviour in their unconfined compressive strength with respect to the rock bedding. This behaviour is noticed for both intact specimens and specimens soaked for 100 days in water and in LFs. The unconfined compressive strength of intact MQS in the vertical direction was higher than the strength of intact shale in the horizontal direction. Soaking effects are also evident in the presented results where strength reduction was observed for different soaking fluids. The unconfined compressive strength of MQS in the vertical direction (i.e. perpendicular to the rock beddings) has considerably decreased by $62 \%, 56 \%$ and $57 \%$ of the intact shale strength, after being soaked in water, polymer solution and bentonite solution, respectively. However, in the horizontal direction (i.e. parallel to the rock beddings), the soaking effects were less evident, as the unconfined compressive strength decreased by $33 \%, 22 \%$, and $51 \%$ of the intact shale strength, after soaking in water, polymer solution and bentonite solution, respectively. Thus, it can be concluded that soaking effects of polymer solution on the unconfined compressive strength of MQS was less than other fluids in both directions. Whereas that bentonite solution 
caused higher decrease than water in the horizontal direction and less decrease than water in the vertical direction compared to the strength of intact shale.

This trend of behaviour is consistent with the trend noted in the results of the Brazilian split test. The expected mechanism of soaking fluids on the unconfined compressive strength of MQS is suggested to be similar to that explained in the discussion of Brazilian split test results. The polymer solution appears to be more efficient than bentonite solution in creating thicker coating layer on the contact surface of MQS. The thick polymer coating layer prevents water from penetration deeper into the shale and hence reducing micro cracks that affect the shale strength. The variation in the pore water salinity of MQS after soaking period is also presented in Table 3 and Table 4. A higher difference in the pore salinity of MQS can be noticed due to soaking in bentonite solution compared to water and polymer solution. This means a higher diffusion and osmosis of MQS can occur in bentonite solution compared to water and polymer solution. The more diffusion and osmosis can result in more swelling deformations of MQS to occur, which in turn may cause its strength to drop down due to the developed micro-cracks in MQS structure (Lee and Lo 1993).

The stress-strain behaviour of the Queenston shale in the unconfined compression tests is presented in Figure 7 and Figure 8. These figures show stress-strain curves of MQS before and after being soaked in water and LFs in the vertical and horizontal directions. The main observation that can be noted from these figures is that although the shape of the stress-strain curve is quite similar in all cases, all used fluids have caused significant drop in the strength of MQS. Vertical specimens showed higher strength at failure than horizontal specimens. The lateral strain of vertical specimens is higher than lateral strain of horizontal specimens in the 
direction parallel to the rock bedding. Cracks were observed in most vertical specimens prior to failure which influenced the shape of the stress-strain curve. Moreover, the strain in the direction of loading in vertical specimens showed a remarkable increase at the initial stage of the test with a slight increase in the strength compared to horizontal specimens. This can be observed in all vertical specimens tested before and after soaking. This behaviour indicates that MQS has stronger fabric structure in the horizontal direction and the influence of soaking fluids is more evident in the vertical direction with respect to the rock bedding.

Fig. 9 shows the cracks developed in MQS and failure modes of intact and soaked specimens tested vertically and horizontally with respect to rock beddings. Photos in Fig. 9 were captured from video records during failure. Fig. 9 shows that the failure of MQS was in general brittle. The brittle failure was more obvious in intact specimens than soaked specimens. In general, failures occurred in vertical planes across the rock beddings for vertically cored specimens, whereas for horizontally cored specimens, most failures occurred along the rock bedding. This is consistent with observations reported by Ghazvinian et al. (2015). They also indicated that for the Queenston shale, failure of horizontal samples occurred quicker than failure of vertical samples after the crack initiation. For the tested MQS, no pure shear failure was noticed in samples of both directions. However, for horizontally cored specimens, some shear wedges appeared after one or more cracks been developed in the rock beddings. This indicates that MQS has a strong fabric structure and the failure occurred when a considerable compression stress was reached to induce tensile stresses on the perpendicular directions to the applied load (i.e. similar to the tensile stresses induced in Brazilian split test). When the ultimate tensile strength in weak bonds was reached, tension failures started to develop along weak planes (i.e. crack initiation). Tension failures across the direction of the applied load were developed consecutively (i.e. crack 
propagation) until the final collapse of the specimen in compression was occurred. The process of developing the tensile cracks that induced the final collapse of the test specimens occurred so fast which supports the observed brittle failure of MQS.

\section{Poisson's Ratio, Elastic Modulus, and Shear Modulus}

MQS is a rock formation of sedimentary origins and as such its elastic deformation parameters, such as Poisson's ratio, elastic modulus and shear modulus, are expected to vary in the orthogonal directions with respect to rock beddings. Thus, Poisson's ratio was measured for both vertical and horizontal specimens. For horizontal specimens, it was measured in two perpendicular directions (i.e. parallel to rock beddings denoted as $\mu_{\mathrm{h}}$ and across rock beddings denoted as $\left.\mu_{\mathrm{h} v}\right)$. Based on the elastic deformations of MQS during the unconfined compression tests, Poisson's ratio and elastic and shear moduli were calculated employing the relationships given in Lo and Hori (1979). The unconfined compression test results show that lateral deformations occurred in vertical specimens (Fig. 7) were generally greater than lateral deformations occurred in horizontal specimens (Fig. 8). Moreover, lateral deformations of soaked specimens were greater in the vertical specimens than horizontal specimens.

From the data presented in Table 3 and Table 4, it can be noted that the variation in Poisson's ratio, elastic modulus and shear modulus due to soaking were more evident in the vertical direction (i.e. perpendicular to rock beddings) than in the horizontal direction (i.e. parallel to rock beddings). Soaking MQS in water, polymer and bentonite solutions caused Poisson's ratio to increase by $(62 \%, 62 \%$, and $45 \%)$ in the vertical direction $\left(\mu_{\mathrm{vn}}\right)$, and to decrease by $(1-10 \%)$ in the horizontal direction $\left(\mu_{\mathrm{h}}\right)$, respectively. However, water caused an increase of $19 \%$ in Poisson's ratio in the horizontal direction perpendicular to rock beddings (i.e. $\mu \mathrm{hv}$ ). In contrast, 
soaking MQS in water and LFs caused the elastic modulus and shear modulus to decrease compared to its value in intact specimens. The change was generally greater in the vertical direction than the change in the horizontal direction. The polymer solution caused a decrease of $(57 \%$ and $62 \%)$ in the elastic modulus and shear modulus in the vertical direction and (11\% and $9 \%)$ in the horizontal direction, while bentonite solution caused a decrease of $(75 \%$ and $77 \%)$ in the vertical direction, and (49\%) in the horizontal direction.

It can be concluded that MQS showed a considerable variation in the unconfined compressive strength and the elastic properties, such as Poisson's ratio, elastic modulus and shear modulus when exposed to water and LFs for a period of time. These variations should be considered in the design of underground structures in MQS when water and other fluids are expected to be acting in the vicinity of excavation. However, the extent of these variations that may occur in MQS from the source of fluids needs to be investigated.

\section{Triaxial Compression Test}

The triaxial compression test was carried out on vertically and horizontally oriented MQS specimens following the procedure described in methods "A" and "B" in ASTM-D7012 (2010). The deformation strain was measured using electronic foil strain gauges. Elastic membrane was used to jacket the test specimen and part of the platens with silicon and O-rings to seal the specimen from the confining fluid. Silicon was applied 24 hours prior to the beginning of the test to allow for adequate setting time. After placing the specimen in the cell with the confining fluid filling the cell chamber, a suitable seating load $<1 \%$ of anticipated ultimate strength was applied to ensure contact between all parts. The confining pressure was applied gradually at constant rate 
of $0.03 \mathrm{MPa} / \mathrm{s}$ until the desired value was achieved, and then the vertical loading was increased at a constant rate until failure was achieved within 2-15 minutes (ASTM-D7012, 2010). Since the piston of the cell has bigger diameter than the test specimen, a correction was made to the vertical applied load through accounting for the difference in the cross-sectional areas of the test specimen and the cell piston. The triaxial test was performed on intact MQS specimens and on specimens that been soaked for 100 days in LFs and in water. Twenty-four tests were conducted on horizontally oriented MQS specimens under confining pressure of 2.5, 5.0, 7.5, 10.0, 15.0, and 20.0 MPa. Due to the limited supplied samples, only 16 tests were performed on vertically oriented MQS specimens, under confining pressure of 2.5, 5.0, 10.0, and 20.0 MPa. The desired confining pressure was maintained stable during the test within the allowable tolerance indicated in ASTM-D7012 (2010). The test results are presented in Tables 5 and 6, and Fig. 10 displays the failure modes. Sample results of the triaxial compression test performed on MQS before and after soaking in LFs and in water are presented in Fig. 11 and Fig. 12.

\section{Discussion}

The triaxial test data presented in Tables 5 and 6 revealed that the influence of increasing the confining pressure from 2.5 $\mathrm{MPa}$ to $20 \mathrm{MPa}$ on the strength was more evident in the horizontal direction. Soaking effects are also listed in these tables as the percentage of decrease in the compressive strength. The percentage decrease in the compressive strength of vertical specimens due to soaking in water and in LFs was generally greater than the decrease in horizontal specimens. Moreover, polymer solution caused the least decrease in the strength of MQS 
compared to water and bentonite solution, which had approximately similar percentage strength decrease in both directions.

The calculated Poisson's ratio was generally increased after soaking in water and LFs in both vertical and horizontal directions. However, some of horizontal specimens exhibit smaller values of Poisson's ratio compared to intact MQS, which could be attributed to the variation in shale. As defined by Lo and Hori (1979), Poisson's ratio for the effect of horizontal stress on vertical strain (i.e. $\mu_{\mathrm{hv}}$ ) was generally greater than Poisson's ratio of the effect of horizontal stress on horizontal strain (i.e. $\mu_{\mathbf{h}}$ ) for horizontal specimens. The elastic modulus and shear modulus were generally decreased after soaking MQS in water and LFs. The decrease in both factors was more evident in vertical specimens. Some specimens showed an increase in the elastic modulus and shear modulus, which might be attributed to the variation in MQS.

Fig. 10 shows the cracks developed and failure modes of vertical and horizontal MQS specimens under confining pressure of $20 \mathrm{MPa}$. In a similar manner to the unconfined compression tests, the failure generally developed along vertical planes across rock beddings for vertical specimens and in multiple planes along rock beddings for horizontal specimens. Shear failures occurred only in intact vertical specimens (Fig. 10-a-1) at an angle of $60-70^{\circ}$ with the horizontal. Soaked specimens showed similar failure trend with no distinct difference for different fluids. However, failures were less brittle than failures in unconfined compression test.

The strength behaviour of MQS in the triaxial compression test is presented in Figure 11 and Figure 12 for vertical and horizontal specimens, respectively. These figures show the stressstrain curves under 5.0 MPa confining pressure. Soaking MQS in water and LFs have caused significant decrease in the strength of both vertically and horizontally cored specimens with 
respect to the rock bedding. However, the more significant decrease occurred in the vertical direction. In a comparable manner to the unconfined compression tests, the lateral strain of vertical specimens is higher than the lateral strain of horizontal specimens in the direction parallel to the rock bedding. Specimens soaked in polymer solution show smaller strain prior to failure compared to specimens soaked in water and bentonite solution. The reverse can be observed in the stress-strain curves of specimens soaked in bentonite solution. This trend of behaviour can be noted in both directions. The effect of the applied confining pressure is more evident in the horizontal direction. The difference in strength of horizontal specimens before and after soaking is smaller than the difference in vertical specimens. These trends of behaviour indicate that MQS has a stronger fabric in the direction parallel to the rock bedding.

\section{Constructing Strength Envelopes of MQS}

The measured strength of MQS from the comprehensive test program performed in this research was used to develop strength envelopes of MQS in the vertical and horizontal directions utilizing RocLab software. The strength envelopes were developed for intact MQS and for MQS after being exposed for 100 days to water, polymer solution and bentonite solution. The change in MQS strength with increasing the confining pressure is presented in the form of principal stresses in Fig. 13. The solid curves in Fig. 13 represent the strength envelopes of MQS developed using RocLab software while the solid points represent measured values from the test program performed in this research. The developed strength envelopes represent peak strength of MQS in both tension and compression states. These envelops were established based on average values of the tensile strength and the unconfined compression strength and single triaxial 
compression strength of MQS under different confining pressure. It is obvious that getting more data points of the triaxial portion of the curves supports confidence in the produced envelopes, but this was not possible due to the limited samples of MQS. Despite of this limitation in the presented data, it is believed that adopting average values of the unconfined compression strength and the tensile strength can produce reliable strength envelopes. It can be revealed that the change in strength of MQS after soaking in water and LFs is generally more evident in the vertical direction (Fig. 13-a). The decrease in MQS strength after soaking in water and LFs was less in the horizontal direction (Fig. 13-b) than the decrease in strength in the vertical direction (Fig. 13-a). Strength envelope of MQS after soaking in polymer solution was relatively higher compared to other fluids. The strength envelopes for MQS after being exposed to water and LFs show significant variation in the strength compared to intact rock strength. These findings are consistent with those observed by Wasantha and Ranjith (2014), Liang et al. (2012), and Lo et al. (1979). These findings should be useful for the design of infrastructures constructed in these shales. It is clearly indicated in the strength envelopes developed for MQS that a considerable amount of the strength of these Shales can be lost after the exposure to water and LFs. The minimal impact on the strength of MQS was caused by polymer solution compared to water and bentonite solution. By developing these strength envelopes, it is quite clear that adopting the intact strength envelope of MQS may lead to overestimation of the rock strength in the zone influenced by water or LFs, which in turn may lead to less accurate design of structures built in these shales.

\section{Summary and Conclusions}


As part of a research to investigate the feasibility of micro-tunnelling technique in Queenston Shale of Southern Ontario, a comprehensive test program was conducted on Milton Queenston Shale utilizing Brazilian split, direct tension, unconfined compression, and triaxial compression tests. These tests were performed on vertical and horizontal specimens with respect to rock beddings to account for strength anisotropy. Specimens were divided into four groups in both directions prior to perform the aforementioned tests: intact (i.e. as received from site), and soaked for 100 days in water, polymer solution, and bentonite solution. Total of 101 tests were performed on Milton Queenston Shale and results were used in RocLab software to develop the strength envelopes in both directions for the four cases. The developed strength envelopes can be used to represent the strength of Milton Queenston Shale in vertical and horizontal directions, at any confining stress (i.e. horizontal in-situ stress) up to $20 \mathrm{MPa}$, for the affected zone by water and lubricant fluids, and the unaffected zone. These strength envelopes can lead to more accurate design of structures built in Milton Queenston Shale. From this study, the following conclusions can be drawn:

1) Milton Queenston Shale showed a significant decrease in their strength after soaking in water, bentonite solution, and polymer solution. This finding is consistent with that reported in the literature for similar shales in Southern Ontario (Lo et al. 1979), and for other type of rocks in other parts of the world (Wasantha and Ranjith 2014; Liang et al. 2012).

2) Milton Queenston Shale kept exhibiting the anisotropic strength behaviour after soaking in water, bentonite solution, and polymer solution. With respect to rock beddings, the 
strength of intact Milton Queenston Shale in vertical direction is greater than the strength in horizontal direction, while the reverse is true after soaking.

3) The compression failure of Milton Queenston Shale was brittle in general. It is believed that cracks were initiated upon tension failure occurrence at weak bonds and the quick crack propagation across rock beddings in the vertical direction, and along rock beddings in horizontal direction.

4) Poisson's ratio increased in both vertical and horizontal directions while elastic modulus and shear modulus decreased after soaking Milton Queenston Shale in water, bentonite solution, and polymer solution.

5) Among fluids used in this research, polymer solution caused the least decrease in strength of Milton Queenston Shale, while bentonite solution caused the highest influence.

6) The developed strength envelopes of Milton Queenston Shale in both vertical and horizontal directions were found to be considerably influenced by the exposure to water and lubricant fluids. The developed strength envelopes can provide a clear insight of the amount of Milton Queenston Shale strength that can be lost due to the continuous exposure to water and lubricant fluids. However, the extent of influence of water and lubricant fluids into these Shales needs further investigation.

\section{Acknowledgement}

The presented work forms part of a comprehensive research program performed in the Geotechnical Research Centre at the University of Western Ontario to investigate the feasibility 
of micro-tunnelling technique in swelling shales of Southern Ontario. The authors would like to thank Ward \& Burke Microtunnelling Ltd. gratefully for their valuable financial and technical support, and for being pioneers in adopting micro-tunnelling technique in swelling rocks of Southern Ontario.

\section{References}

Al-Maamori, H.M.S., El Naggar, M.H., and Micic, S. 2014. A compilation of the geomechanical properties of rocks in Southern Ontario and the neighbouring regions. Open Journal of Geology, 4: 10-27. doi.10.4236/ojg.2014.45017

Al-Maamori, H.M.S., El Naggar, M.H., Micic, S., and Lo, K.Y. 2016. Influence of lubricant fluids on swelling behaviour of Queenston shale in southern Ontario. Canadian Gotechnical Journal, (available online: doi: 10.1139/cgj-2015-0300).

ASTM- D7012 2010. Standard test method for compressive strength and elastic moduli of intact rock core specimens under varying states of stress and temperatures. ASTM International, West Conshohocken, Pa.

ASTM- D2216 2010. Standard Test Methods for Laboratory Determination of Water (Moisture) Content of Soil and Rock by Mass. ASTM International, West Conshohocken, Pa.

ASTM- D2936 2008. Standard test method for direct tensile strength of intact rock core specimens. ASTM International, West Conshohocken, Pa. 
ASTM- D3967 2008. Standard test method for splitting tensile strength of intact rock core specimens. ASTM International, West Conshohocken, Pa.

ASTM-D4543 2008. Standard practices for preparing rock core as cylindrical test specimens and verifying conformance to dimensional and shape tolerances. ASTM International, West Conshohocken, Pa.

Baud, P., Zhu, W., and Wong, T. 2000. Failure Mode and Weakening Effect of Water on Sandstone. Journal of Geophysical Research, 105: 16371-16389.

Claesson, J., and Bohloli, B. 2002. Brazilian test: stress field and tensile strength of anisotropic rocks using an analytical solution. International Journal of Rock Mechanics and Mining Sciences, 39: 991-1004.

Closmann, P.J., and Bradley, W.B. 1979. The Effect of Temperature on Tensile and Compressive Strengths and Young's Modulus of Oil Shale. Society of Petroleum Engineers Journal, 19(5): 301-313. doi: http://dx.doi.org/10.2118/6734-PA.

Colback, P.S.B., and Wiid, B.L. 1965. The Influence of Moisture Content on the Compressive Strength of Rock. Rock Mechanics Symposium, Ottawa 1965. University of Toronto, Deptartment of Mines and Technical Surveys, pp. 65-84.

Dan, D.Q., Konietzky, H., and Herbst, M. 2013. Brazilian tensile strength tests on some anisotropic rocks. International Journal of Rock Mechanics and Mining Sciences, 58: 1-7.

Dreimanis, A. 1962. Quantitative Gasometric Determination of Calcite and Dolomite By Using Chittick Apparatus. Journal of Sedimentary Petrology, 32(3): 520 - 529. 
Ghazvinian, E., Diederichs, M.S., Labrie, D., and Martin, C.D. 2015. An Investigation on the Fabric Type Dependency of the Crack Damage Thresholds in Brittle Rocks. Geotechnical and Geological Engineering, 33(6): 1409-1429.

doi: 10.1007/s10706-015-9909-1.

Gorski, B., Conlon, B., Ljunggren, B., and AB, T. 2007. Determination of the direct and indirect tensile strength on cores from borehole KFM01D. Forsmark Site Investigation Report ISSN 1651-4416, SKB P-07-76, AP PF 400-06-067. CANMET-MMSL, Mining and Mineral Sciences Laboratories, Natural Resources Canada, Svensk Kärnbränslehantering AB, Swedish Nuclear Fuel and Waste Management Co, Stockholm, Sweden.

Hein, F.J., and Longstaffe, F.J. 1983. Geotechnical, sedimentological and mineralogical investigations in Arctic Fjords. In Sedimentology of Arctic Fjords Experiment: HU 82031m Data Report I. Compiled by J.P.M. Syvitski and C.P. Blakeney. Can. Data Rep. Hydrogr. Ocean Sci. 12. pp. 11-1-11-158.

Lee, Y.N. 1988. Stress-strain-time relationship of Queenston shale. Ph.D. thesis, Civil and Environmental Engineering Department, The University of Western Ontario, London, Ontario.

Lee, Y.N., and Lo, K.Y. 1993. The swelling mechanism of Queenston shale. Tunnelling Association of Canada Annual Publication. Canadian Tunnelling, pp. 75-97.

Li, D. and Wong, L.N.Y. 2013. The Brazilian Disc Test for Rock Mechanics Applications: Review and New Insights. Rock Mechanics and Rock Engineering, 46(2): 269-287. doi:10.1007/s00603-012-0257-7. 
Liang, W., Yang, X., Gao, H., Zhang, C., and Zhao, Y. 2012. Experimental study of mechanical properties of gypsum soaked in brine. International Journal of Rock Mechanics and Mining Sciences, 53: 42-50. doi:10.1016/j.ijrmms.2012.05.015.

Lo, K.Y., and Hori, M. 1979. Deformation and strength properties of some rocks in Southern Ontario. Canadian Geotechnical Journal, 16(1): 108-120. doi: 10.1139/t79-010.

Lo, K.Y., Cooke, B.H., and Dunbar, D.D. 1987. Design of buried structures in squeezing rock in Toronto, Canada. Canadian Geotechnical Journal, 24(2): 32-41. doi: 10.1139/t87-028.

Lo, K.Y., Devata, M., Yuen, C.M.K. 1979. Performance of shallow tunnel in a shaly rock with high horizontal stresses. Tunnelling '79, Proceedings of the Second International Symposium on Tunnelling. Institution of Mining and Metallurgy, London, England, Paper 9, pp. 1-12.

Lo, K.Y., Yung, T.C.B., Lukajic, B. 1987. A field method for the determination of rock- mass modulus. Canadian Geotechnical Journal, 24(3): 6-13. doi: 10.1139/t87-051.

Lo, K.Y., Ogawa, T., Lukajic, B., and Dupak, D.D. 1991. Measurements of strength parameters of concrete-rock contact at the dam-foundation interface. Geotechnical Testing Journal,14(4): 83-94. Url: http://worldcat.org/issn/01496115.

Moore, D.M., and Reynolds, R.C., Jr. 1989. X-ray diffraction and the identification and analysis of clay minerals. Oxford University Press, Oxford, New York.

Neville, A.M. 1996. Properties of Concrete. $4^{\text {th }}$ edition, Pearson Education Limited, Harlow, England. 
Paterson, M.S. 1978. Experimental Rock Deformation: The Brittle Field. Springer-Verlag, Berlin.

Paterson, M.S., and Wong, T.F. 2005. Experimental Rock Deformation - The Brittle Field, $2^{\text {nd }}$ Edition. Springer-Verlag, Berlin, Heidelberg, New York. doi:10.1017/S0016756806242973.

Perras, M.A., and Diederichs, M.S. 2014. A Review of the Tensile Strength of Rock: Concepts and Testing. Geotechnical and Geological Engineering, 32: 525-546. doi: 10.1007/s10706-014-9732-0.

Vishal, V., Pradhan, S.P., and Singh, T.N. 2011. Tensile Strength of Rock Under Elevated Temperatures. Geotechnical and Geological Engineering, 29: 1127-1133. doi: 10.1007/s10706-011-9440-y.

Wai, R.S.C., Lo, K.Y., and Rowe, R.K. 1981. Thermal stresses in rocks with nonlinear properties. Research report, Faculty of Engineering Science, The University of Western Ontario, GEOT-8-81.

Wasantha, P.L.P., and Ranjith, P.G. 2014. Water-weakening behavior of Hawkesbury sandstone in brittle regime. Engineering Geology, 178: 91-1. doi:10.1016/j.enggeo.2014.05.015.

Zhang, G., Germaine, J.T., Martin, R.T., and Whittle, A.J. 2003. A simple samplemounting method for random powder x-ray diffraction. Clays and Clay Minerals, 51(2): 218-225. doi:10.1346/CCMN.2003.0510212. 


\section{Figure Captions}

Fig. 1. Borehole logging of recovered samples of Queenston Shale from Milton, Ontario.

Fig. 2. Steps followed to protect specimens during soaking period: a) Intact specimen, b), c) and d) Steps of preserving the specimen during soaking period, e) anf f) Presereved pecimen after soaking period.

Fig. 3. Sectional view of the modified triaxial compression cell: 1)cell body, 2) cell base, 3) central pedestal, 4) piston, 5) ventilation valve, 6) inlet/outlet junction, 7) one-way inlet valve, 8) outlet adjusting valve, 9) outlet needle valve, 10) assembly cap, 11) adjusting seat, 12) adjusting cap, 13) specimen's platen, 14) pressure transducer, 15) sealing gland, 16) electronic foil strain gauge, 17) strain gauge wires, 18) cell chamber, 19) rubber washer and stopper, 20) rubber casket: and 21) rock specimen.

Fig. 4. Schematic drawing of the orientation of specimens in the Brazilian split test.

Fig. 5. Scanning electron microscopy images of Milton Queenston Shale (MQS): a) Vertical surface of intact specimen, b) Horizontal surface of intact specimen, c) Polymer coating on MQS and d) Bentonite coating on MQS.

Fig. 6. Brazilian split test performed on: a) intact specimens and specimens soaked for hundred days in: b) water, c) polymer solution: and d) bentonite solution; 1) Vertical specimens, 2) Horizontal specimen, (these photos were captured from video records at failure). 
Fig.7. Results of unconfined compressive strength performed on vertically cored MQS specimens: a) intact specimen, specimens soaked for hundred days in: b) water, c) polymer solution and d) bentonite solution, respectively.

Fig. 8. Results of unconfined compressive strength performed on horizontally cored MQS specimens: a) intact specimen, specimens soaked for hundred days in: b) water, c) polymer solution and d) bentonite solution, respectively.

Fig. 9. Unconfined compressive strength test performed on: a) intact specimens and specimens soaked for hundred days in: b) water, c) polymer solution: and d) bentonite solution; 1) Vertical specimens, 2) Horizontal specimen, (these photos were captured from video records at failure).

Fig. 10. Triaxial compressive strength test performed on: a) intact specimens and specimens soaked for hundred days in: b) water, c) polymer solution: and d) bentonite solution; 1) Vertical specimens, 2) Horizontal specimen.

Fig. 11. Results of triaxial compression strength performed on vertically cored MQS specimens at $\sigma 3=5.0 \mathrm{MPa}$ : a) intact specimen, specimens soaked for hundred days in: b) water, c) polymer solution and d) bentonite solution, respectively.

Fig. 12. Results of triaxial compression strength performed on horizontally cored MQS specimens at $\sigma 3=5.0 \mathrm{MPa}$ : a) intact specimen, specimens soaked for hundred days in: b) water, c) polymer solution and d) bentonite solution, respectively.

Fig. 13. Strength envelopes of MQS (Intact and after soaking in water, polymer solution and bentonite solution): a) and b) Principal stresses in vertical and horizontal direction, respectively, c) and d) Normal and shear stresses in vertical and horizontal direction, respectively. 
Table 1. Brazilian Splitting Strength of MQS in Vertical Direction and Supplementary Test Results

\begin{tabular}{|c|c|c|c|c|c|c|c|c|c|c|c|c|c|}
\hline $\begin{array}{l}\text { Specimen } \\
\text { No. }\end{array}$ & Ambient Fluid & $\begin{array}{l}\text { Depth } \\
\text { (m) }\end{array}$ & $\begin{array}{l}\text { Calcite } \\
\text { Content } \\
(\%)\end{array}$ & $\begin{array}{c}\text { Dolomite } \\
\text { Content } \\
(\%)\end{array}$ & $\begin{array}{c}\text { Moisture } \\
\text { Content } \\
\text { Before } \\
\text { Soaking } \\
(\%)\end{array}$ & $\begin{array}{c}\text { Moisture } \\
\text { Content } \\
\text { After } \\
\text { Soaking } \\
(\%)\end{array}$ & $\begin{array}{c}\text { Pore } \\
\text { Salinity } \\
\text { Before } \\
\text { Soaking } \\
(\mathrm{g} / \mathrm{L})\end{array}$ & $\begin{array}{c}\text { Pore } \\
\text { Salinity } \\
\text { After } \\
\text { Soaking } \\
\text { (g/L }\end{array}$ & $\begin{array}{c}\text { Percent } \\
\text { Decrease } \\
\text { In Pore } \\
\text { Salinity } \\
(\%)\end{array}$ & $\begin{array}{l}\text { Brazilian } \\
\text { Splitting } \\
\text { Strength } \\
\text { (MPa) }\end{array}$ & $\begin{array}{c}\text { Average } \\
\text { Brazilian } \\
\text { Splitting } \\
\text { Strength } \\
\text { (MPa) }\end{array}$ & $\begin{array}{l}\text { Percentage } \\
\text { Decrease } \\
\text { In } \\
\text { Brazilian } \\
\text { Split } \\
\text { Strength }\end{array}$ & $\begin{array}{c}\text { Equivalent } \\
\text { Direct } \\
\text { Tension } \\
\text { Strength } \\
\sigma \mathrm{t}_{\mathrm{v}} \\
\text { (MPa }\end{array}$ \\
\hline BZVT 1 & Air & 29.921 & 20.2 & 5.8 & 2.454 & - & 206.8 & - & - & 8.189 & & & \\
\hline BZVT 2 & Air & 18.517 & 33.5 & 2.3 & 2.406 & - & 72.7 & - & - & 9.783 & & & \\
\hline BZVT 3 & Air & 28.03 & 24.4 & 7.9 & 2.410 & - & 93.4 & - & - & 9.056 & 8.7 & 0 & 4.5 \\
\hline BZVT 4 & Air & 28.4 & 22.0 & 0.9 & 2.483 & - & 105.7 & - & - & 8.739 & & & \\
\hline BZVT 5 & Air & 15.621 & 25.3 & 2.5 & 2.200 & - & 159.1 & - & - & 7.942 & & & \\
\hline BZVT 6 & Water & 29.934 & 31.4 & 4.8 & 3.122 & 3.810 & 242.6 & 109.4 & 55 & 6.523 & & & \\
\hline BZVT 7 & Water & 27.92 & 24.4 & 7.9 & 2.932 & 3.50 & 134.0 & 44.9 & 67 & 5.516 & & & \\
\hline BZVT 8 & Water & 29.921 & 20.9 & 5.0 & 2.71 & 3.60 & 187.3 & 85.1 & 55 & 5.462 & 6.2 & 29 & 3.2 \\
\hline BZVT 9 & Water & 15.697 & 33.4 & 1.6 & 2.20 & 2.81 & 184.8 & 65.4 & 65 & 7.854 & & & \\
\hline BZVT 10 & Water & 18.517 & 31.4 & 4.8 & 2.012 & 2.55 & 74.6 & 24.0 & 68 & 6.024 & & & \\
\hline BZVT 11 & Water & 28.03 & 19.6 & 8.6 & 2.46 & 3.1 & 195.1 & 69.4 & 64 & 5.682 & & & \\
\hline BZVT 12 & $0.8 \%$ Polymers Solution & 29.934 & 23.9 & 5.2 & 2.297 & 3.130 & 250.3 & 150.5 & 40 & 7.399 & & & \\
\hline BZVT 13 & $0.8 \%$ Polymers Solution & 27.92 & 23.5 & 6.1 & 2.210 & 2.882 & 164.0 & 104.5 & 36 & 7.587 & & & \\
\hline BZVT 14 & $0.8 \%$ Polymers Solution & 29.921 & 19.1 & 4.3 & 2.888 & 3.766 & 175.7 & 104.2 & 41 & 7.464 & 78 & 10 & 4. \\
\hline BZVT 15 & $0.8 \%$ Polymers Solution & 18.567 & 20.8 & 7.3 & 2.184 & 3.493 & 160.3 & 111.3 & 31 & 7.700 & & & \\
\hline BZVT 16 & $0.8 \%$ Polymers Solution & 15.697 & 31.4 & 4.8 & 2.237 & 2.672 & 78.8 & 47.7 & 39 & 8.749 & & & \\
\hline BZVT 17 & $0.8 \%$ Polymers Solution & 26.48 & 21.6 & 8.0 & 2.275 & 2.39 & 73.2 & 52.6 & 28 & 7.786 & & & \\
\hline BZVT 18 & $8 \%$ Bentonite Solution & 29.934 & 23.1 & 9.1 & 2.855 & 3.70 & 227.7 & 43.7 & 81 & 5.094 & & & \\
\hline BZVT 19 & $8 \%$ Bentonite Solution & 27.92 & 23.2 & 2.5 & 2.30 & 2.99 & 157.6 & 35.8 & 77 & 5.021 & & & \\
\hline BZVT 20 & $8 \%$ Bentonite Solution & 18.567 & 25.3 & 2.0 & 2.184 & 3.841 & 183.2 & 56.4 & 69 & 5.199 & 53 & 39 & 28 \\
\hline BZVT 21 & $8 \%$ Bentonite Solution & 15.697 & 33.5 & 2.3 & 2.210 & 2.990 & 70.1 & 14.6 & 79 & 6.218 & & & \\
\hline BZVT 22 & $8 \%$ Bentonite Solution & 26.48 & 24.0 & 9.1 & 2.385 & 3.319 & 136.3 & 36.6 & 73 & 5.364 & & & \\
\hline BZVT 23 & $8 \%$ Bentonite Solution & 15.621 & 23.0 & 5.4 & 2.855 & 3.038 & 145.9 & 40.1 & 73 & 5.004 & & & \\
\hline
\end{tabular}


Table 2. Brazilian Splitting Strength of MQS in Horizontal Direction and Supplementary Test Results

\begin{tabular}{|c|c|c|c|c|c|c|c|c|c|c|c|c|c|}
\hline $\begin{array}{c}\text { Specimen } \\
\text { No. }\end{array}$ & Ambient Fluid & $\begin{array}{l}\text { Depth } \\
\text { (m) }\end{array}$ & $\begin{array}{c}\text { Calcite } \\
\text { Content } \\
(\%)\end{array}$ & $\begin{array}{c}\text { Dolomite } \\
\text { Content } \\
(\%)\end{array}$ & $\begin{array}{c}\text { Moisture } \\
\text { Content } \\
\text { Before } \\
\text { Soaking } \\
(\%)\end{array}$ & $\begin{array}{c}\text { Moisture } \\
\text { Content } \\
\text { After } \\
\text { Soaking } \\
(\%)\end{array}$ & $\begin{array}{c}\text { Pore } \\
\text { Salinity } \\
\text { Before } \\
\text { Soaking } \\
(\mathrm{g} / \mathrm{L})\end{array}$ & $\begin{array}{c}\text { Pore } \\
\text { Salinity } \\
\text { After } \\
\text { Soaking } \\
\text { (g/L }\end{array}$ & $\begin{array}{c}\text { Percent } \\
\text { Decrease } \\
\text { In Pore } \\
\text { Salinity } \\
(\%)\end{array}$ & $\begin{array}{c}\text { Brazilian } \\
\text { Splitting } \\
\text { Strength } \\
(\mathrm{MPa})\end{array}$ & $\begin{array}{c}\text { Average } \\
\text { Brazilian } \\
\text { Splitting } \\
\text { Strength } \\
\text { (MPa) }\end{array}$ & $\begin{array}{c}\text { Percentage } \\
\text { Decrease } \\
\text { In } \\
\text { Brazilian } \\
\text { Split } \\
\text { Strength }\end{array}$ & $\begin{array}{c}\text { Equivalent } \\
\text { Direct } \\
\text { Tension } \\
\text { Strength } \\
\sigma \text { th } \\
(\mathrm{MPa})\end{array}$ \\
\hline BZHT 1 & Air & 22.331 & 26.9 & 2.5 & 2.604 & - & 87.4 & - & - & 8.948 & & & \\
\hline BZHT 2 & Air & 22.518 & 26.0 & 2.2 & 2.786 & - & 125.6 & - & - & 7.499 & 7.6 & 0 & 4.0 \\
\hline BZHT 3 & Air & 23.14 & 22.9 & 6.4 & 2.516 & - & 196.7 & - & - & 6.463 & & & \\
\hline BZHT 4 & Water & 22.4 & 31.6 & 2.7 & 2.165 & 2.564 & 144.8 & 55.1 & 62 & 3.277 & & & \\
\hline BZHT 5 & Water & 22.523 & 33.5 & 2.3 & 2.484 & 3.225 & 72.9 & 29.2 & 60 & 3.439 & 3.3 & 57 & 1.7 \\
\hline BZHT 6 & Water & 23.25 & 25.7 & 2.3 & 2.516 & 2.717 & 180.8 & 57.8 & 68 & 3.126 & & & \\
\hline BZHT 7 & $0.8 \%$ Polymers Solution & 22.429 & 29.7 & 3.9 & 2.551 & 2.564 & 78.4 & 47.6 & 39 & 4.871 & & & \\
\hline BZHT 8 & $0.8 \%$ Polymers Solution & 22.7 & 36.2 & 2.7 & 1.952 & 1.952 & 124.3 & 88.7 & 29 & 5.711 & 5.0 & 34 & 2.6 \\
\hline BZHT 9 & $0.8 \%$ Polymers Solution & 22.97 & 21.7 & 6.1 & 2.091 & 2.683 & 152.2 & 102.4 & 33 & 4.452 & & & \\
\hline BZHT 10 & $8 \%$ Bentonite Solution & 22.6 & 27.5 & 2.90 & 2.20 & 3.36 & 109.8 & 37.6 & 66 & 3.658 & & & \\
\hline BZHT 11 & $8 \%$ Bentonite Solution & 22.96 & 26.6 & 3.9 & 2.035 & 2.889 & 154.3 & 36.0 & 77 & 3.242 & 3.4 & 55 & 1.8 \\
\hline BZHT 12 & $8 \%$ Bentonite Solution & 23.24 & 22.9 & 6.4 & 2.516 & 3.120 & 125.4 & 34.0 & 73 & 3.274 & & & \\
\hline
\end{tabular}


Table 3. Unconfined Compression Strength and Strength Parameters of Milton Queenston Shale (MQS) in Vertical Direction and Supplementary Test Results

\begin{tabular}{|c|c|c|c|c|c|c|c|c|c|c|c|c|c|c|c|c|c|}
\hline $\begin{array}{l}\text { Specimen } \\
\text { No. }\end{array}$ & Ambient Fluid & $\begin{array}{l}\text { Depth } \\
\text { (m) }\end{array}$ & $\begin{array}{l}\text { Calcite } \\
\text { Content } \\
(\%)\end{array}$ & $\begin{array}{c}\text { Dolomite } \\
\text { Content } \\
(\%)\end{array}$ & $\begin{array}{c}\text { Moisture } \\
\text { Content } \\
\text { Before } \\
\text { Soaking } \\
(\%)\end{array}$ & $\begin{array}{c}\text { Moisture } \\
\text { Content } \\
\text { After } \\
\text { Soaking } \\
(\%)\end{array}$ & $\begin{array}{c}\text { Pore } \\
\text { Salinity } \\
\text { Before } \\
\text { Soaking } \\
(\mathrm{g} / \mathrm{L})\end{array}$ & $\begin{array}{c}\text { Pore } \\
\text { Salinity } \\
\text { After } \\
\text { Soaking } \\
\text { (g/L }\end{array}$ & $\begin{array}{c}\text { Percent } \\
\text { Decrease } \\
\text { in Pore } \\
\text { Salinity } \\
(\%)\end{array}$ & $\begin{array}{l}\text { Unconfined } \\
\text { Compression } \\
\text { Strength } \\
\text { (MPa) }\end{array}$ & $\begin{array}{c}\text { Average } \\
\text { Unconfined } \\
\text { Compression } \\
\text { Strength } \\
\text { (MPa) }\end{array}$ & $\begin{array}{c}\text { Poisson's } \\
\text { Ratio } \\
\mu_{\mathrm{vh}}\end{array}$ & $\begin{array}{c}\text { Average } \\
\text { Poisson's } \\
\text { Ratio } \\
\mu_{\mathrm{vh}}\end{array}$ & $\begin{array}{c}\begin{array}{c}\text { Elastic } \\
\text { Modulus } \\
\mathrm{E}_{\mathrm{V}} \\
(\mathrm{GPa})\end{array}\end{array}$ & $\begin{array}{c}\text { Average } \\
\text { Elastic } \\
\text { Modulus } \mathrm{Ev}_{\mathrm{v}} \\
(\mathrm{GPa})\end{array}$ & \begin{tabular}{c}
\multicolumn{2}{c}{ Shear } \\
Modulus \\
$\mathrm{G}_{\mathrm{v}} \quad(\mathrm{GPa})$
\end{tabular} & $\begin{array}{c}\text { Average } \\
\text { Shear } \\
\text { Modulus } \\
\mathrm{Gv} \\
(\mathrm{GPa})\end{array}$ \\
\hline UCVT 1 & Air & 24.48 & 22.1 & 7.1 & 2.81 & - & 213.4 & - & - & 53.100 & & 0.273 & & 15.150 & & 5.951 & \\
\hline UCVT 2 & Air & 31.54 & 16.1 & 3.0 & 2.38 & - & 221.3 & - & - & 43.751 & 42.861 & 0.231 & 0.268 & 20.732 & 16.794 & 8.421 & 6.650 \\
\hline UCVT 3 & Air & 31.70 & 17.2 & 2.2 & 2.95 & - & 156.7 & - & - & 31.732 & & 0.300 & & 14.500 & & 5.577 & \\
\hline UCVT 4 & Water & 24.63 & 25.2 & 2.7 & 2.60 & 2.67 & 149.2 & 52.9 & 65 & 24.769 & & 0.356 & & 7.656 & & 2.823 & \\
\hline UCVT 5 & Water & 26.97 & 23.7 & 2.7 & 2.97 & 3.73 & 87.2 & 31.6 & 64 & 11.881 & $\begin{array}{l}16.364 \\
(-62 \%)\end{array}$ & 0.470 & $\begin{array}{l}0.434 \\
(62 \%)\end{array}$ & 6.000 & $\begin{array}{c}6.773 \\
(-60 \%)\end{array}$ & 2.041 & $\begin{array}{c}2.374 \\
(-64 \%)\end{array}$ \\
\hline UCVT 6 & Water & 29.38 & 20.1 & 3.2 & 2.84 & 3.53 & 158.9 & 52.6 & 67 & 12.443 & & 0476 & & 6.664 & & 2.257 & \\
\hline UCVT 7 & $0.8 \%$ Polymers Solution & 27.40 & 24.9 & 2.7 & 2.60 & 3.00 & 91.8 & 73.6 & 20 & 25.433 & & 0.477 & & 8.065 & & 2.730 & \\
\hline UCVT 8 & $0.8 \%$ Polymers Solution & 29.57 & 26.2 & 2.0 & 2.76 & 2.90 & 118.7 & 88.4 & 25 & 15.689 & $\begin{array}{l}18.917 \\
(-56 \%)\end{array}$ & 0.351 & $\begin{array}{l}0.434 \\
(62 \%)\end{array}$ & 7.914 & $\begin{array}{c}7.292 \\
(-57 \%)\end{array}$ & 2.929 & $\begin{array}{c}2.553 \\
(-62 \%)\end{array}$ \\
\hline UCVT 9 & $0.8 \%$ Polymers Solution & 24.76 & 22.3 & 3.6 & 2.67 & 3.25 & 206.0 & 124.7 & 39 & 15.630 & & 0.475 & & 5.896 & & 1.999 & \\
\hline UCVT 10 & $8 \%$ Bentonite Solution & 25.66 & 25.9 & 3.2 & 2.97 & 3.20 & 228.6 & 69.4 & 70 & 25.610 & & 0.384 & & 4.032 & & 1.457 & \\
\hline UCVT 11 & $8 \%$ Bentonite Solution & 25.79 & 25.4 & 3.0 & 2.97 & 3.00 & 229.0 & 33.8 & 85 & 15.100 & $\begin{array}{l}18.471 \\
(-57 \%)\end{array}$ & 0.458 & $\begin{array}{l}0.389 \\
(45 \%)\end{array}$ & 2.893 & $\begin{array}{l}4.183 \\
(-75 \%)\end{array}$ & 0.992 & $\begin{array}{c}1.524 \\
(-77 \%)\end{array}$ \\
\hline UCVT 12 & $8 \%$ Bentonite Solution & 29.69 & 22.5 & 4.8 & 2.78 & 3.10 & 119.4 & 24.4 & 80 & 14.702 & & 0.325 & & 5.625 & & 2.123 & \\
\hline
\end{tabular}

Values in brackets represent percentage variation in the strength and elastic deformation parameters due to soaking in LF and in water compared to intact specimens 
Table 4. Unconfined Compression Strength and Strength Parameters of Milton Queenston Shale (MQS) in Horizontal Direction and Supplementary Test Results

\begin{tabular}{|c|c|c|c|c|c|c|c|c|c|c|c|c|c|c|c|c|c|}
\hline \multirow{2}{*}{$\begin{array}{l}\text { Specimen } \\
\text { No. }\end{array}$} & \multirow[t]{2}{*}{ Ambient Fluid } & \multirow{2}{*}{$\begin{array}{l}\text { Depth } \\
\text { (m) }\end{array}$} & \multirow{2}{*}{$\begin{array}{l}\text { Calcite } \\
\text { Content } \\
(\%)\end{array}$} & \multirow{2}{*}{$\begin{array}{c}\text { Dolomite } \\
\text { Content } \\
(\%)\end{array}$} & \multirow{2}{*}{$\begin{array}{c}\text { Moisture } \\
\text { Content } \\
\text { Before } \\
\text { Soaking } \\
(\%)\end{array}$} & \multirow{2}{*}{$\begin{array}{c}\text { Moisture } \\
\text { Content } \\
\text { After } \\
\text { Soaking } \\
(\%)\end{array}$} & \multirow{2}{*}{$\begin{array}{c}\text { Pore } \\
\text { Salinity } \\
\text { Before } \\
\text { Soaking } \\
\text { (g/L) }\end{array}$} & \multirow{2}{*}{$\begin{array}{c}\text { Pore } \\
\text { Salinity } \\
\text { After } \\
\text { Soaking } \\
\text { (g/L }\end{array}$} & \multirow{2}{*}{$\begin{array}{c}\text { Percent } \\
\text { Decrease } \\
\text { in Pore } \\
\text { Salinity } \\
(\%)\end{array}$} & \multirow{2}{*}{$\begin{array}{l}\text { Unconfined } \\
\text { Compression } \\
\text { Strength } \\
\text { (MPa) }\end{array}$} & \multirow{2}{*}{\begin{tabular}{|c|} 
Average \\
Unconfined \\
Compression \\
Strength \\
(MPa)
\end{tabular}} & \multirow{2}{*}{$\begin{array}{l}\text { Poisson's Ratio } \\
\text { (parallel to bedding, } \\
\mu \mathrm{h} / \text { perpendicular } \\
\text { to bedding, } \mu \mathrm{hv} \text { ) }\end{array}$} & \multirow{2}{*}{$\begin{array}{c}\text { Average } \\
\text { Poisson's } \\
\text { Ratio } \mu \mathrm{h} \\
/ \mu \mathrm{hv}\end{array}$} & \multirow{2}{*}{$\begin{array}{c}\text { Elastic } \\
\text { Modulus } \\
\mathrm{E}_{\mathrm{h}} \\
(\mathrm{GPa})\end{array}$} & \multirow{2}{*}{$\begin{array}{c}\text { Average } \\
\text { Elastic } \\
\text { Modulus } \\
\mathrm{E}_{\mathrm{h}} \\
(\mathrm{GPa})\end{array}$} & \multirow{2}{*}{$\begin{array}{c}\text { Shear } \\
\text { Modulus } \\
\text { Gh }(\mathrm{GPa})\end{array}$} & \multirow{2}{*}{$\begin{array}{c}\text { Average } \\
\text { Shear } \\
\text { Modulus } \\
\mathrm{Gh} \quad(\mathrm{GPa})\end{array}$} \\
\hline & & & & & & & & & & & & & & & & & \\
\hline UCHT 1 & Air & 15.65 & 24.6 & 11.7 & 2.20 & - & 72.7 & - & - & 44.956 & & $0.250 / 0.357$ & & 21.853 & & 8.741 & \\
\hline UCHT 2 & Air & 25.14 & 21.4 & 2.9 & 3.88 & - & 91.2 & - & - & 23.171 & & $0.222 / 0.333$ & & 22.200 & & 9.083 & \\
\hline UCHT 3 & Air & 27.50 & 20.6 & 4.8 & 2.73 & - & 103.8 & - & - & 22.161 & 30.885 & $0.270 / 0.313$ & $0.249 / 0.333$ & 26.647 & 23.093 & 10.491 & 9.241 \\
\hline UCHT 4 & Air & 15.67 & 30.1 & 1.8 & 2.55 & - & 78.4 & - & - & 33.251 & & $0.253 / 0.330$ & & 21.670 & & 8.647 & \\
\hline UCHT 5 & Water & 17.76 & 28.6 & 3.8 & 2.30 & 2.50 & 155.4 & 62.8 & 60 & 27.144 & & $0.309 / 0.393$ & & 12.356 & & 4.720 & \\
\hline UCHT 6 & Water & 25.90 & 30.3 & 1.8 & 2.01 & 2.66 & 224.3 & 86.9 & 61 & 17.131 & $\begin{array}{l}20.825 \\
(-33 \%)\end{array}$ & $0.222 / 0.278$ & $\begin{array}{c}0.246 / 0.397 \\
(-1 \% / 19 \%)\end{array}$ & 33.330 & $\begin{array}{l}19.007 \\
(-18 \%)\end{array}$ & 13.637 & $\begin{array}{l}7.683 \\
(-17 \%)\end{array}$ \\
\hline UCHT 7 & Water & 27.98 & 25.3 & 2.5 & 2.60 & 3.30 & 152.7 & 55.7 & 64 & 18.200 & & $0.208 / 0.519$ & & 11.334 & & 4.691 & \\
\hline UCHT 8 & $0.8 \%$ Polymers Solution & 15.60 & 26.6 & 4.3 & 2.47 & 2.92 & 91.1 & 60.5 & 34 & 18.440 & & $0.235 / 0.329$ & & 16.920 & & 6.850 & \\
\hline UCHT 9 & $0.8 \%$ Polymers Solution & 25.05 & 23.3 & 4.3 & 2.40 & 2.73 & 72.9 & 43.1 & 41 & 25.210 & $\begin{array}{l}24.112 \\
(-22 \%)\end{array}$ & $0.200 / 0.338$ & \begin{tabular}{|l|}
$0.225 / 0.325$ \\
$(-10 \% /-2 \%)$
\end{tabular} & 18.014 & $\begin{array}{l}20.539 \\
(-11 \%)\end{array}$ & 7.506 & $\begin{array}{l}8.372 \\
(-9 \%)\end{array}$ \\
\hline UCHT 10 & $0.8 \%$ Polymers Solution & 28.01 & 19.9 & 5.0 & 2.40 & 2.52 & 97.7 & 69.3 & 29 & 28.685 & & $0.240 / 0.307$ & & 26.682 & & 10.759 & \\
\hline UCHT 11 & $8 \%$ Bentonite Solution & 15.57 & 25.1 & 2.8 & 3.11 & 3.63 & 99.3 & 29.0 & 71 & 13.303 & & $0.250 / 0.353$ & & 11.565 & & 4.626 & \\
\hline UCHT 12 & $8 \%$ Bentonite Solution & 24.98 & 25.4 & 3.0 & 2.72 & 3.42 & 97.7 & 30.4 & 69 & 14.794 & $\begin{array}{l}15.052 \\
(-51 \%)\end{array}$ & $0.264 / 0.361$ & $\begin{array}{c}0.242 / 0.334 \\
(-3 \% / 0 \%)\end{array}$ & 17.779 & $\begin{array}{l}11.677 \\
(-49 \%)\end{array}$ & 7.033 & $\begin{array}{c}4.669 \\
(-49 \%)\end{array}$ \\
\hline UCHT 13 & $8 \%$ Bentonite Solution & 28.38 & 20.9 & 5.4 & 2.61 & 3.09 & 101.9 & 20.1 & 80 & 17.058 & & $0.211 / 0.289$ & & 5.686 & & 2.348 & \\
\hline
\end{tabular}

Values in brackets represent percentage variation in the strength and elastic deformation parameters due to soaking in LF and in water compared to intact specimens 
Table 5. Triaxial Compression Strength and Strength Parameters of Milton Queenston Shale (MQS) in Vertical Direction and Supplementary Test Results

\begin{tabular}{|c|c|c|c|c|c|c|c|c|c|c|c|c|c|c|c|c|c|}
\hline $\begin{array}{l}\text { Specimen } \\
\text { No. }\end{array}$ & Ambient Fluid & $\begin{array}{l}\text { Depth } \\
\text { (m) }\end{array}$ & $\begin{array}{c}\text { Calcite } \\
\text { Content } \\
(\%)\end{array}$ & $\begin{array}{l}\text { Dolomite } \\
\text { Content } \\
(\%)\end{array}$ & $\begin{array}{c}\text { Moisture } \\
\text { Content } \\
\text { Before } \\
\text { Soaking } \\
(\%)\end{array}$ & $\begin{array}{l}\text { Moisture } \\
\text { Content } \\
\text { After } \\
\text { Soaking } \\
(\%)\end{array}$ & $\begin{array}{c}\text { Pore } \\
\text { Salinity } \\
\text { Before } \\
\text { Soaking } \\
(\mathrm{g} / \mathrm{L})\end{array}$ & $\begin{array}{c}\text { Pore } \\
\text { Salinity } \\
\text { After } \\
\text { Soaking } \\
(\mathrm{g} / \mathrm{L}\end{array}$ & $\begin{array}{c}\text { Percent } \\
\text { Decrease } \\
\text { in Pore } \\
\text { Salinity } \\
(\%)\end{array}$ & $\begin{array}{l}\text { Confining } \\
\text { Pressure } \\
\text { (MPa) }\end{array}$ & \begin{tabular}{|c} 
Triaxial \\
Compression \\
Strength \\
(MPa)
\end{tabular} & $\begin{array}{c}\text { Percentage } \\
\text { Decrease in } \\
\text { Triaxial } \\
\text { Compression } \\
\text { Strength }\end{array}$ & $\begin{array}{c}\text { Poisson's } \\
\text { Ratio } \\
\mu_{\mathrm{vh}}\end{array}$ & $\begin{array}{l}\text { Percentage } \\
\text { increase in } \\
\text { Poisson's } \\
\text { Ratio (\%) }\end{array}$ & $\begin{array}{c}\text { Elastic } \\
\text { Modulus } \\
E_{v} \\
(\mathrm{GPa})\end{array}$ & $\begin{array}{c}\text { Percentage } \\
\text { decrease in } \\
\text { Elastic } \\
\text { Modulus } \\
(\%)\end{array}$ & $\begin{array}{c}\text { Shear } \\
\text { Modulus }= \\
E_{\mathrm{v}} / \\
2\left(1+\mu_{\mathrm{vh}}\right) \\
(\mathrm{GPa})\end{array}$ \\
\hline TXCVT 3 & Air & 26.01 & 27.5 & 2.2 & 2.60 & - & 88.7 & - & - & 2.5 & 59.200 & - & 0.322 & - & 15.130 & - & 5.722 \\
\hline TXCVT 1 & Air & 22.80 & 22.1 & 2.7 & 2.49 & - & 140.8 & - & - & 5.0 & 63.255 & - & 0.259 & - & 19.240 & - & 7.641 \\
\hline TXCVT 2 & Air & 25.30 & 21.2 & 7.6 & 2.59 & & 210.8 & - & - & 10.0 & 91.870 & - & 0.225 & - & 17.500 & - & 7.143 \\
\hline TXCVT 4 & Air & 32.09 & 16.3 & 4.8 & 2.26 & - & 154.6 & - & - & 20.0 & 112.360 & - & 0.217 & - & 26.908 & - & 11.055 \\
\hline TXCVT 7 & Water & 31.82 & 18.2 & 4.8 & 2.74 & 3.10 & 174.6 & 70.9 & 59 & 2.5 & 24.730 & 58 & 0.333 & 3 & 7.333 & 52 & 2.751 \\
\hline TXCVT 6 & Water & 28.20 & 20.6 & 5.9 & 2.97 & 3.73 & 109.2 & 39.0 & 64 & 5.0 & 25.425 & 60 & 0.493 & 47 & 6.746 & 65 & 2.259 \\
\hline TXCVT 5 & Water & 32.21 & 20.5 & 2.2 & 2.40 & 2.85 & 156.7 & 101.9 & 35 & 10.0 & 27.941 & 70 & 0.270 & 17 & 5.184 & 70 & 2.041 \\
\hline TXCVT 8 & Water & 31.98 & 18.6 & 4.3 & 2.65 & 3.25 & 141.9 & 37.2 & 74 & 20.0 & 34.966 & 68.9 & 0.300 & 28 & 34.000 & -26 & 13.077 \\
\hline TXCVT 9 & $0.8 \%$ Polymers Solution & 23.26 & 21.0 & 6.4 & 2.52 & 3.10 & 198.7 & 122.1 & 39 & 2.5 & 19.987 & 66 & 0.368 & 13 & 7.368 & 51 & 2.693 \\
\hline TXCVT 10 & $0.8 \%$ Polymers Solution & 27.10 & 26.1 & 6.2 & 2.85 & 3.04 & 88.5 & 72.5 & 18 & 5.0 & 25.112 & 60 & 0.429 & 40 & 12.012 & 38 & 4.203 \\
\hline TXCVT 12 & $0.8 \%$ Polymers Solution & 23.09 & 23.5 & 11.5 & 2.48 & 3.40 & 171.5 & 65.2 & 62 & 10.0 & 33.107 & 64 & 0.293 & 23 & 14.064 & 20 & 5.439 \\
\hline TXCVT 11 & $0.8 \%$ Polymers Solution & 29.20 & 23.6 & 9.3 & 2.35 & 2.51 & 133.4 & 85.2 & 36 & 20.0 & 48.644 & 56.7 & 0.302 & 28 & 25.397 & 9 & 9.753 \\
\hline TXCVT 15 & $8 \%$ Bentonite Solution & 29.10 & 16.4 & 4.5 & 2.51 & 3.84 & 124.9 & 30.1 & 76 & 2.5 & 19.735 & 67 & 0.353 & 9 & 4.707 & 83 & 1.739 \\
\hline TXCVT 16 & $8 \%$ Bentonite Solution & 32.78 & 15.5 & 3.2 & 2.60 & 3.40 & 211.5 & 31.9 & 85 & 5.0 & 20.370 & 68 & 0.467 & 45 & 3.336 & 98 & 1.137 \\
\hline TXCVT 14 & $8 \%$ Bentonite Solution & 25.50 & 25.4 & 3.0 & 2.82 & 2.97 & 240.8 & 38.2 & 84 & 10.0 & 23.033 & 75 & 0.400 & 44 & 24.000 & -37 & 8.571 \\
\hline TXCVT 13 & $8 \%$ Bentonite Solution & 23.89 & 19.3 & 4.1 & 2.23 & 3.56 & 145.2 & 31.9 & 78 & 20.0 & 27.186 & 75.8 & 0.283 & 23 & 3.773 & 92 & 1.470 \\
\hline
\end{tabular}


Table 6. Triaxial Compression Strength and Strength Parameters of Milton Queenston Shale (MQS) in Horizontal Direction and Supplementary Test Results

\begin{tabular}{|c|c|c|c|c|c|c|c|c|c|c|c|c|c|c|c|c|}
\hline $\begin{array}{l}\text { Specimen } \\
\text { No. }\end{array}$ & Ambient Fluid & $\begin{array}{l}\text { Depth } \\
\text { (m) }\end{array}$ & $\begin{array}{c}\text { Calcite } \\
\text { Content } \\
(\%)\end{array}$ & $\begin{array}{c}\text { Dolomite } \\
\text { Content } \\
(\%)\end{array}$ & $\begin{array}{c}\text { Moisture } \\
\text { Content } \\
\text { Before } \\
\text { Soaking } \\
(\%)\end{array}$ & $\begin{array}{c}\text { Moisture } \\
\text { Content } \\
\text { After } \\
\text { Soaking } \\
(\%)\end{array}$ & $\begin{array}{c}\text { Pore } \\
\text { Salinity } \\
\text { Before } \\
\text { Soaking } \\
(\mathrm{g} / \mathrm{L})\end{array}$ & $\begin{array}{l}\text { Pore } \\
\text { Salinity } \\
\text { After } \\
\text { Soaking } \\
\text { (g/L }\end{array}$ & $\begin{array}{c}\text { Percent } \\
\text { Decrease } \\
\text { in Pore } \\
\text { Salinity } \\
(\%)\end{array}$ & $\begin{array}{l}\text { Confining } \\
\text { Pressure } \\
\text { (MPa) }\end{array}$ & $\begin{array}{c}\text { Triaxial } \\
\text { Compression } \\
\text { Strength } \\
\text { (MPa) }\end{array}$ & $\begin{array}{c}\text { Percentage } \\
\text { Decrease in } \\
\text { triaxial } \\
\text { Compression } \\
\text { strength } \\
(\%)\end{array}$ & $\begin{array}{c}\text { Poisson's Ratio } \\
\text { (parallel to } \\
\text { bedding, } \mu \mathrm{h} \\
\text { /perpendicular } \\
\text { to bedding, } \\
\mu \text { hv) }\end{array}$ & $\begin{array}{l}\text { Percentage } \\
\text { Increase in } \\
\text { Poisson's } \\
\text { Ratio (\%) }\end{array}$ & $\begin{array}{c}\text { Elastic } \\
\text { Modulus } \\
\text { Eh } \\
\text { (GPa) }\end{array}$ & $\begin{array}{c}\text { Shear } \\
\text { Modulus } \\
=\mathrm{Eh} / \\
2(1+\mu \mathrm{h}) \\
(\mathrm{GPa})\end{array}$ \\
\hline TXCHT 3 & Air & 21.03 & 18.4 & 6.9 & 3.54 & - & 73.8 & - & - & 2.5 & 36.883 & - & $0.250 / 0.375$ & - & 50.000 & 20.000 \\
\hline TХСНT 4 & Air & 26.30 & 21.6 & 4.8 & 2.98 & - & 70.4 & - & - & 5.0 & 38.477 & - & $0.313 / 0.328$ & - & 31.269 & 11.907 \\
\hline TХCHT 5 & Air & 26.46 & 22.1 & 6.1 & 3.06 & - & 195.9 & - & - & 7.5 & 54.861 & - & $0.276 / 0.395$ & - & 32.887 & 12.887 \\
\hline TXCHT 2 & Air & 20.96 & 23.5 & 10.3 & 3.20 & - & 151.9 & - & - & 10.0 & 58.781 & - & $0.164 / 0.309$ & - & 47.318 & 20.326 \\
\hline ТХСНТ 1 & Air & 19.05 & 21.5 & 12.4 & 2.47 & - & 80.5 & - & - & 15.0 & 91.042 & - & $0.211 / 0.253$ & - & 27.419 & 11.321 \\
\hline TXСНT 6 & Air & 19.48 & 33.5 & 2.3 & 2.55 & - & 88.2 & - & - & 20.0 & 114.700 & - & $0.230 / 0.230$ & - & 69.622 & 28.302 \\
\hline ТХCHT 9 & Water & 21.16 & 21.9 & 3.0 & 2.90 & 3.70 & 134.0 & 50.1 & 63 & 2.5 & 23.932 & 35 & $0.259 / 0.324$ & $4 /-14$ & 29.443 & 16.400 \\
\hline ТХCHT 11 & Water & 26.34 & 19.9 & 4.8 & 2.35 & 3.51 & 210.6 & 55.1 & 74 & 5.0 & 26.949 & 30 & $0.286 / 0.393$ & $-9 / 20$ & 66.712 & 25.938 \\
\hline тХСНT 10 & Water & 28.35 & 20.7 & 5.2 & 2.55 & 2.85 & 148.8 & 64.5 & 57 & 7.5 & 27.454 & 64 & $0.214 / 0.500$ & $-22 / 27$ & 15.704 & 6.468 \\
\hline TXСНT 12 & Water & 27.88 & 19.3 & 3.4 & 2.43 & 3.79 & 161.6 & 49.7 & 69 & 10.0 & 37.017 & 37 & $0.217 / 0.478$ & $32 / 55$ & 34.741 & 14.273 \\
\hline TXСНT 8 & Water & 20.83 & 23.3 & 4.5 & 3.21 & 3.60 & 94.9 & 39.2 & 59 & 15.0 & 38.400 & 58 & $0.389 / 0.424$ & $84 / 68$ & 111.127 & 40.003 \\
\hline TXCHT 7 & Water & 19.08 & 25.3 & 2.3 & 2.22 & 2.95 & 141.2 & 58.6 & 59 & 20.0 & 69.821 & 40 & $0.311 / 0.335$ & $35 / 31$ & 33.593 & 12.812 \\
\hline TXСНT 13 & $0.8 \%$ Polymers Solution & 19.23 & 22.1 & 9.8 & 2.80 & 2.99 & 80.3 & 59.9 & 25 & 2.5 & 32.216 & 13 & $0.239 / 0.392$ & $-4 / 5$ & 21.752 & 8.778 \\
\hline TXCHT 17 & $0.8 \%$ Polymers Solution & 27.95 & 19.0 & 7.5 & 2.13 & 2.68 & 105.3 & 61.6 & 41 & 5.0 & 34.138 & 11 & $0.320 /-$ & $2 /-$ & 160.000 & 60.606 \\
\hline TХCHT 14 & $0.8 \%$ Polymers Solution & 20.88 & 22.0 & 6.3 & 3.18 & 3.32 & 70.9 & 51.1 & 28 & 7.5 & 44.288 & 19 & $0.416 / 0.444$ & $51 / 12$ & 832.250 & 293.874 \\
\hline ТХСНT 18 & $0.8 \%$ Polymers Solution & 19.53 & 32.9 & 2.9 & 2.35 & 2.75 & 95.7 & 64.2 & 33 & 10.0 & 50.669 & 14 & $0.385 / 0.423$ & $135 / 37$ & 153.909 & 55.563 \\
\hline TXCHT 15 & $0.8 \%$ Polymers Solution & 26.38 & 26.9 & 10.7 & 2.53 & 2.80 & 77.0 & 55.9 & 27 & 15.0 & 62.113 & 32 & $0.286 / 0.381$ & $36 / 51$ & 26.205 & 10.189 \\
\hline TXCHT 16 & $0.8 \%$ Polymers Solution & 27.53 & 23.6 & 9.3 & 2.35 & 2.51 & 133.4 & 85.2 & 36 & 20.0 & 71.635 & 38 & $0.378 / 0.378$ & $64 / 64$ & 1188.000 & 431.060 \\
\hline TXCHT 20 & $8 \%$ Bentonite Solution & 21.01 & 21.7 & 5.0 & 2.50 & 3.34 & 76.4 & 14.1 & 82 & 2.5 & 16.713 & 55 & $0.323 / 0.355$ & $29 /-5$ & 27.121 & 10.250 \\
\hline TXCHT 22 & $8 \%$ Bentonite Solution & 27.56 & 21.1 & 6.8 & 2.41 & 2.68 & 95.0 & 26.0 & 73 & 5.0 & 28.052 & 27 & $0.211 / 0.268$ & $-33 /-18$ & 25.751 & 10.632 \\
\hline
\end{tabular}




\begin{tabular}{|c|c|c|c|c|c|c|c|c|c|c|c|c|c|c|c|c|}
\hline TXCHT 21 & $8 \%$ Bentonite Solution & 26.42 & 21.2 & 5.0 & 2.54 & 3.37 & 161.9 & 36.6 & 77 & 7.5 & 34.706 & 37 & $0.385 / 0.423$ & $39 / 16$ & 67.335 & 24.309 \\
\hline ТХСНT 19 & $8 \%$ Bentonite Solution & 19.30 & 24.4 & 12.5 & 2.01 & 2.69 & 141.4 & 37.2 & 74 & 10.0 & 45.335 & 23 & $0.370 / 0.370$ & $126 / 20$ & 18.500 & 6.752 \\
\hline TXCHT 24 & $8 \%$ Bentonite Solution & 19.58 & 26.0 & 2.0 & 2.10 & 2.90 & 76.4 & 19.0 & 75 & 15.0 & 55.183 & 39 & $0.259 / 0.353$ & $23 / 40$ & 29.424 & 11.685 \\
\hline TXCHT 23 & $8 \%$ Bentonite Solution & 28.06 & 19.3 & 4.1 & 2.23 & 3.56 & 145.2 & 31.9 & 78 & 20.0 & 60.765 & 47 & $0.262 / 0.299$ & $14 / 30$ & 39.739 & 15.744 \\
\hline
\end{tabular}




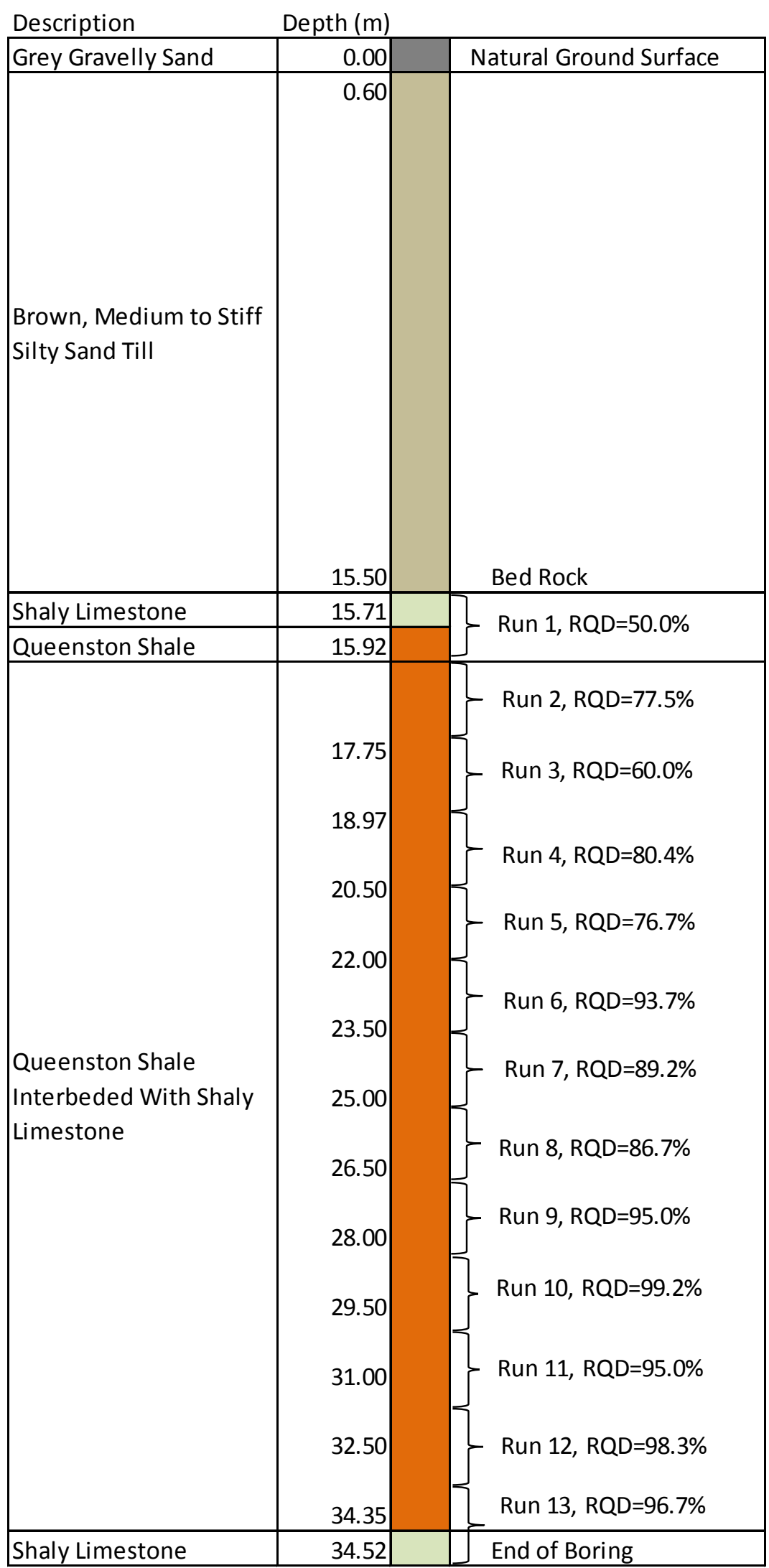

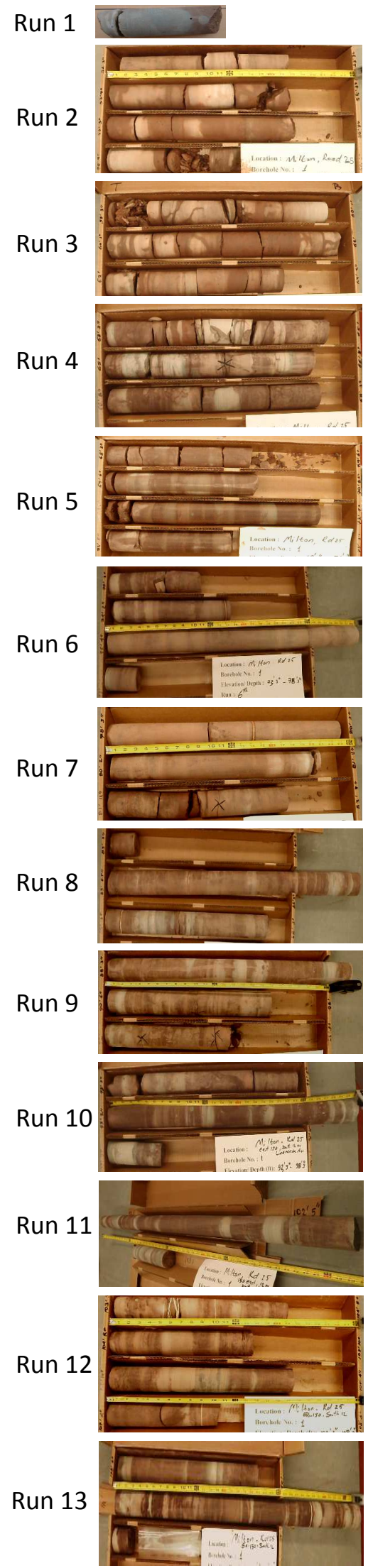

Fig. 1. Borehole logging of recovered samples of Queenston Shale from Milton, Ontario. 


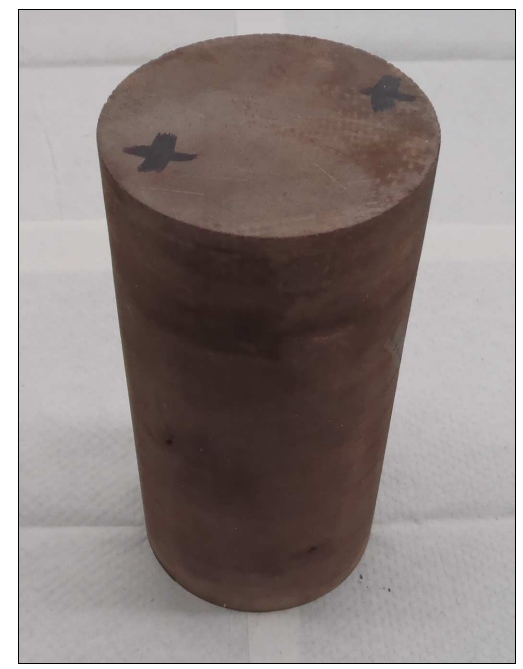

a)

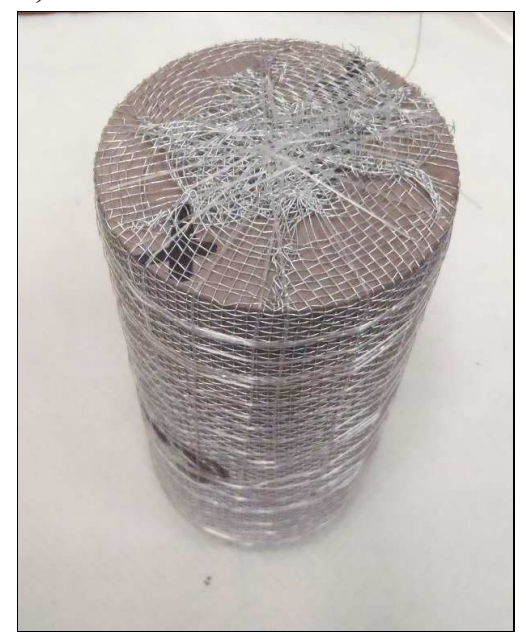

d)

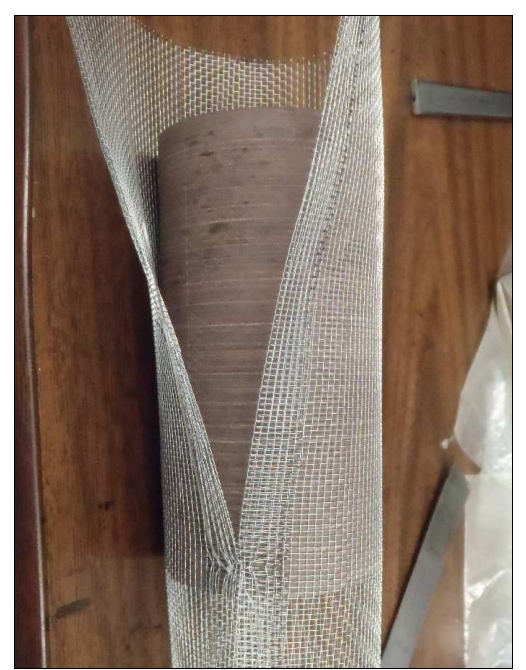

b)

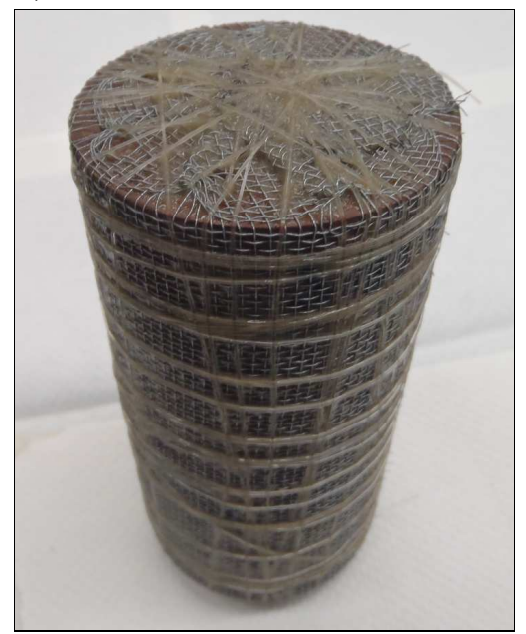

e)

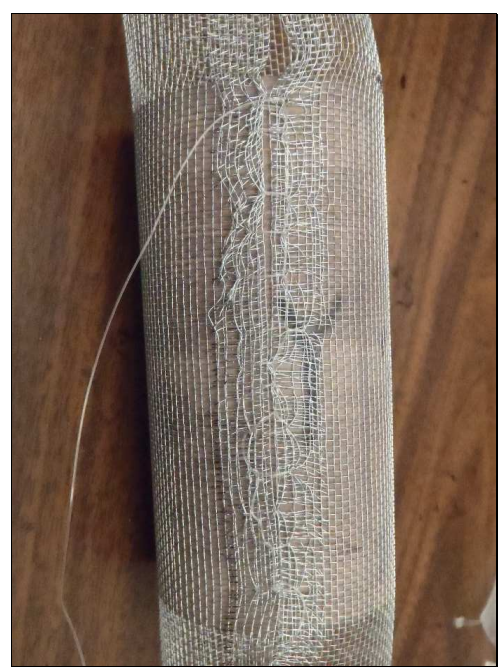

c)

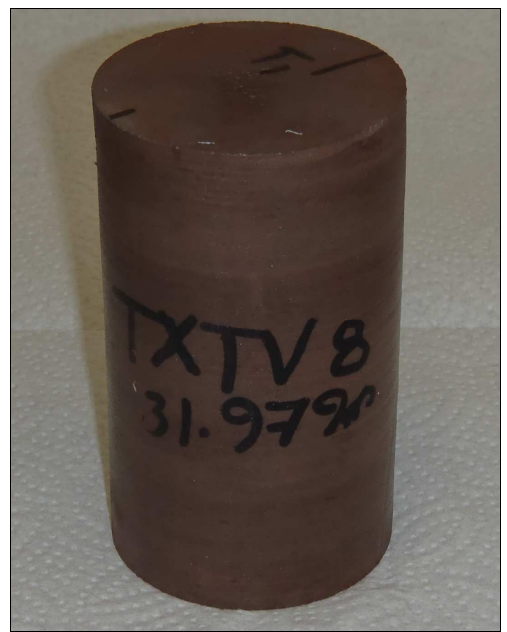

f)

Fig. 2. Steps followed to protect specimens during soaking period: a) Intact specimen, b), c) and d) Steps of preserving the specimen during soaking period, e) anf f) Presereved pecimen after soaking period. 


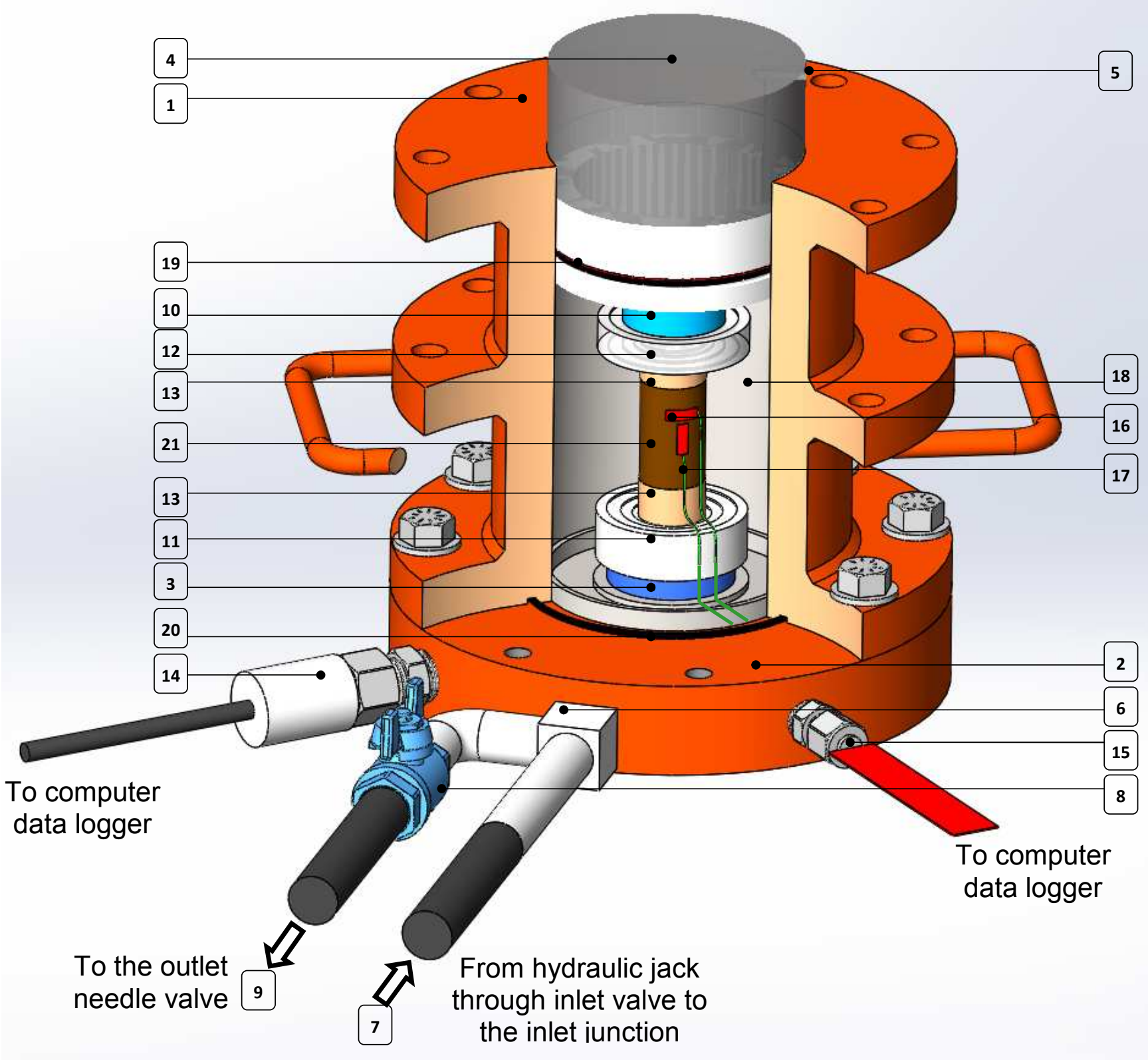

Fig. 3. Sectional view of the modified triaxial compression cell: 1)cell body, 2) cell base, 3) central pedestal, 4) piston, 5) ventilation valve, 6) inlet/outlet junction, 7) one-way inlet valve, 8) outlet adjusting valve, 9) outlet needle valve, 10) assembly cap, 11) adjusting seat, 12) adjusting cap, 13) specimen's platen, 14) pressure transducer, 15) sealing gland, 16) electronic foil strain gauge, 17) strain gauge wires, 18) cell chamber, 19) rubber washer and stopper, 20) rubber casket: and 21) rock specimen. 


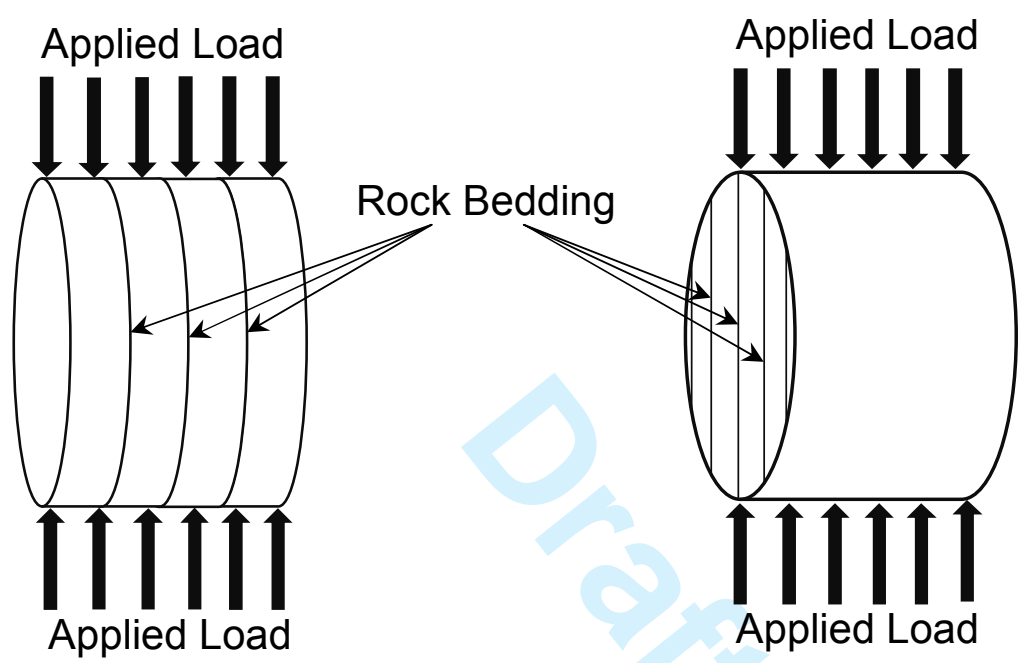

Vertically cored specimen Horizontally cored specimen for splitting strength in the horizontal direction for splitting strength in the vertical direction

Fig. 4. Schematic drawing of the orientation of specimens in the Brazilian split test. 


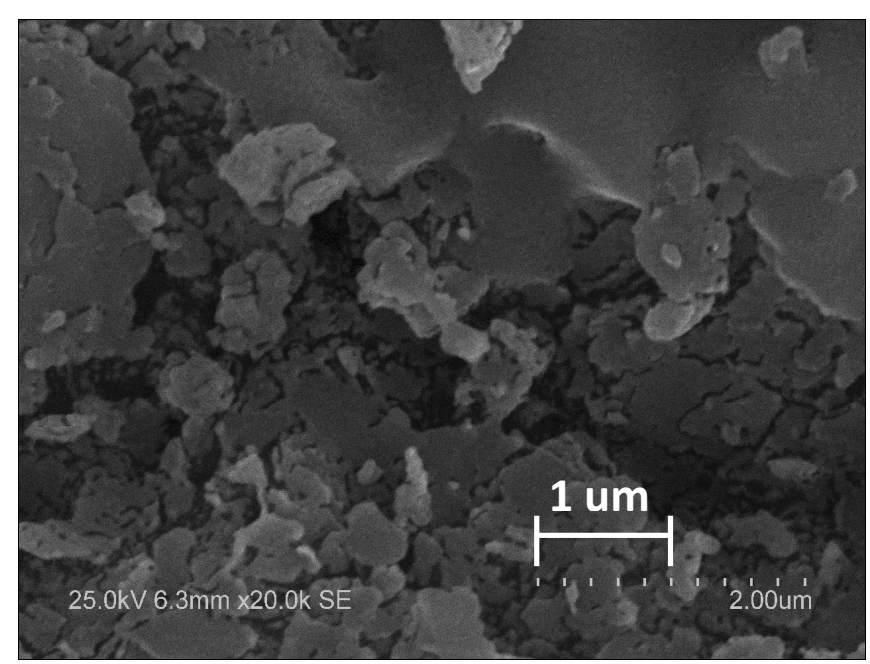

a) Vertical surface of intact MQS

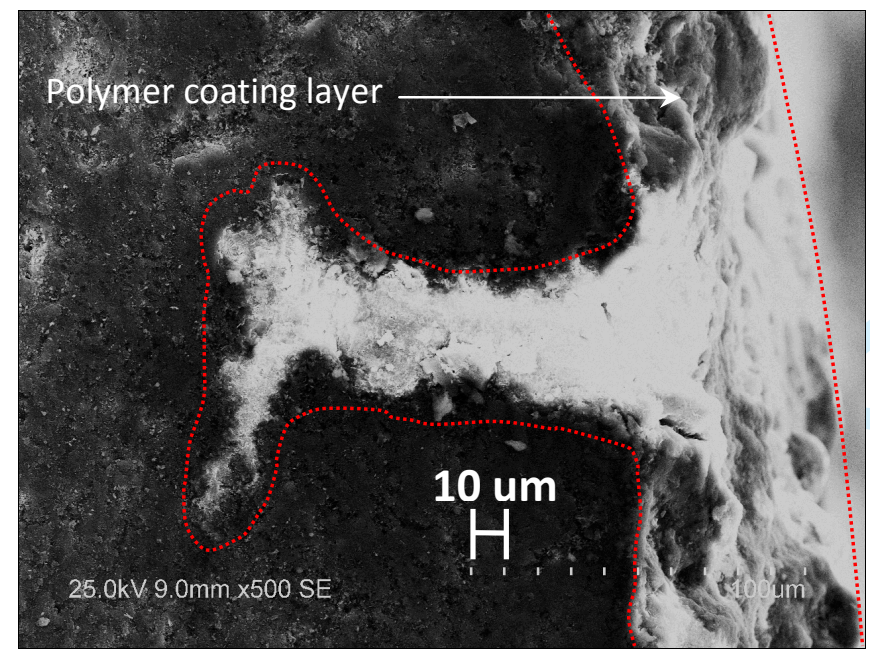

c) MQS after soaking in polymer solution

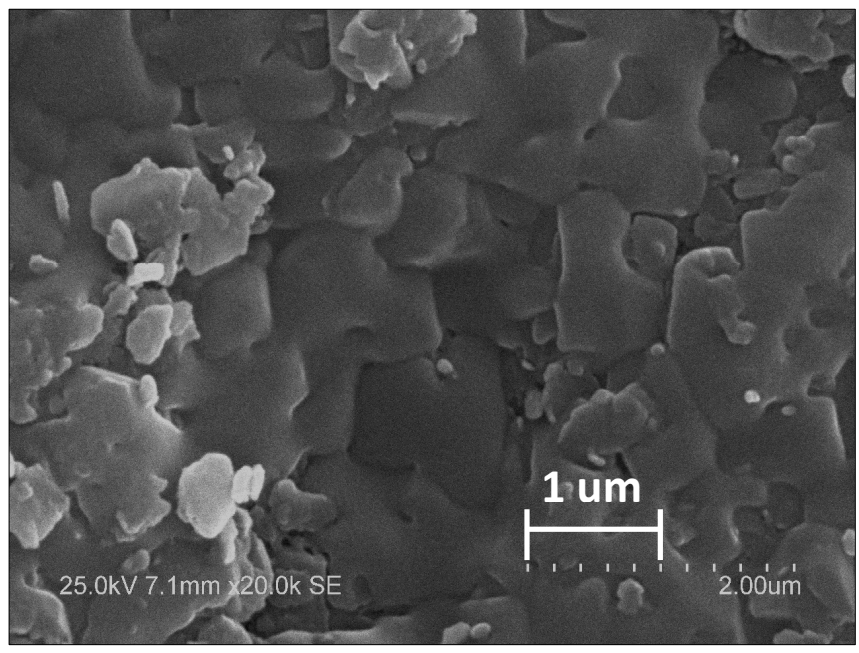

b) Horizontal surface of intact MQS

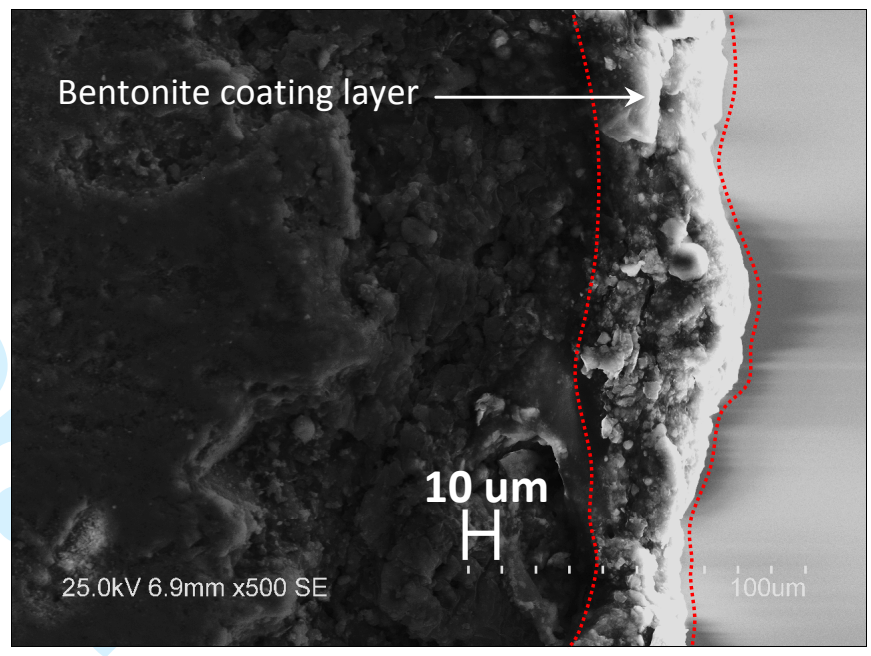

d) MQS after soaking in bentonite solution

Fig. 5. Scanning electron microscopy images of Milton Queenston Shale (MQS): a) Vertical surface of intact specimen, b) Horizontal surface of intact specimen, c) Polymer coating on MQS and d) Bentonite coating on MQS. 
a) Intact specimens:

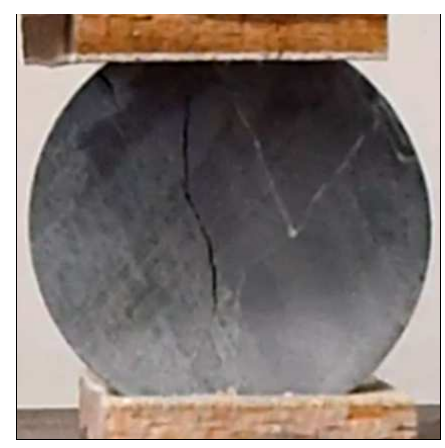

1) Vertical strength test

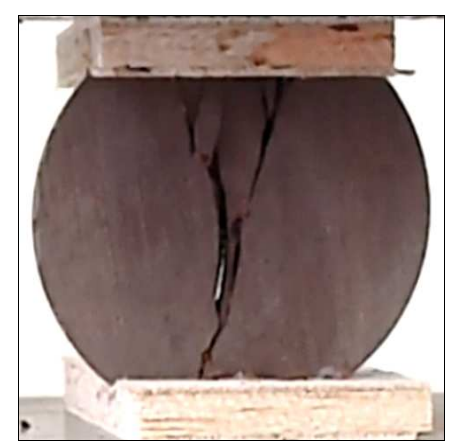

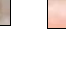 \\ (1)}
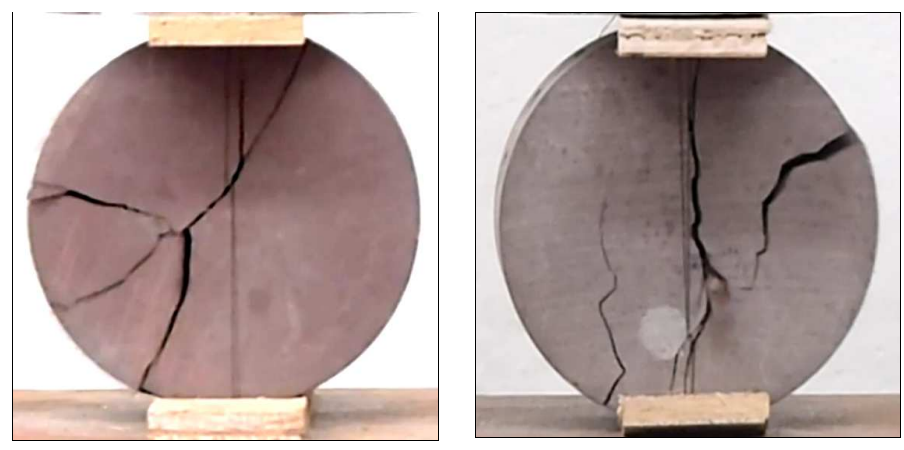

2) Horizontal strength test

b) Specimens soaked in water:

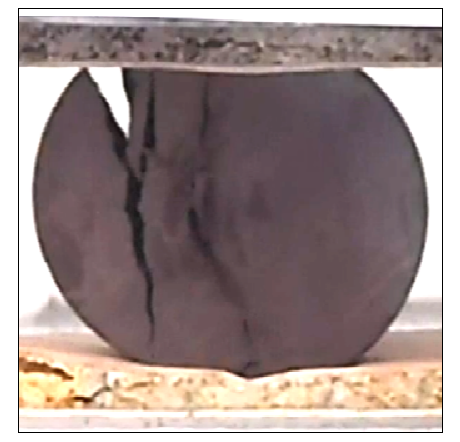

1) Vertical strength test
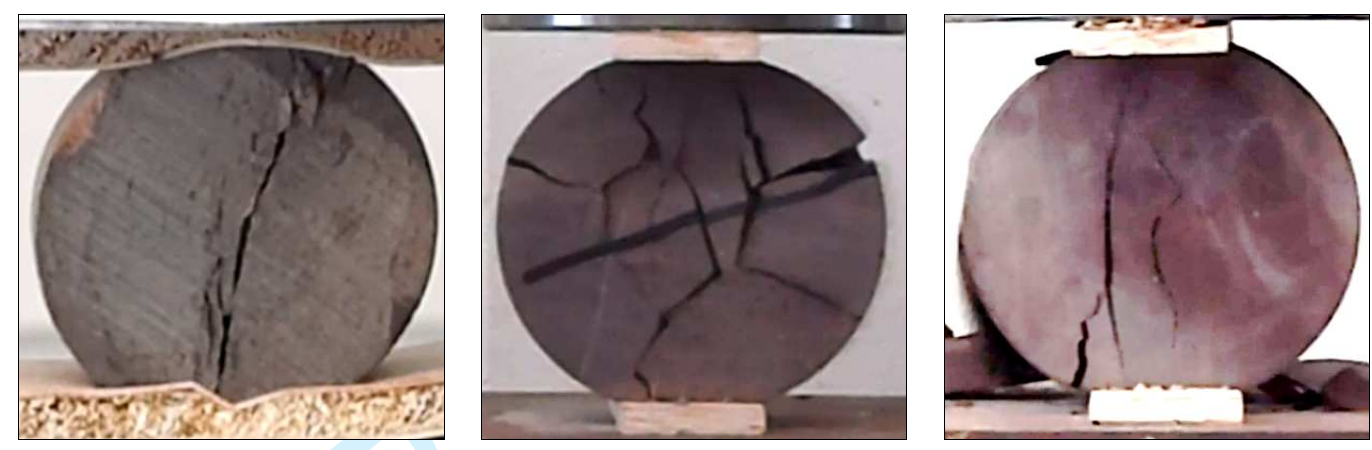

2) Horizontal strength test

c) Specimens soaked in polymer solution:

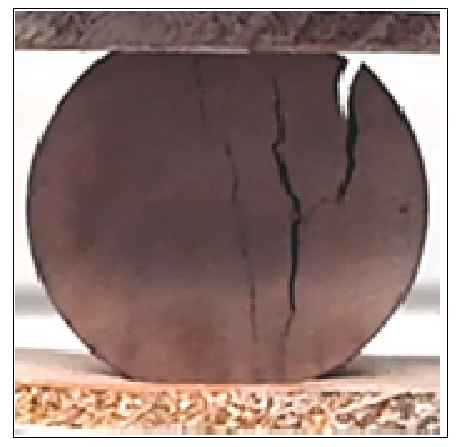

1) Vertical strength test

d) Specimens soaked in bentonite solution:

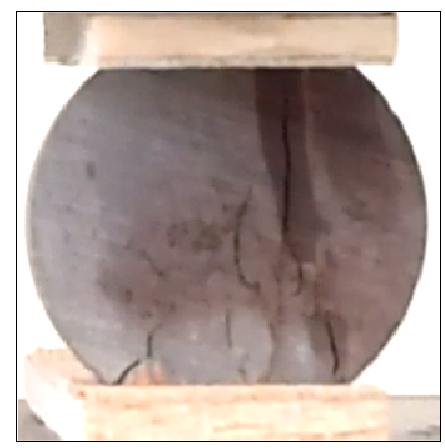

1) Vertical strength test
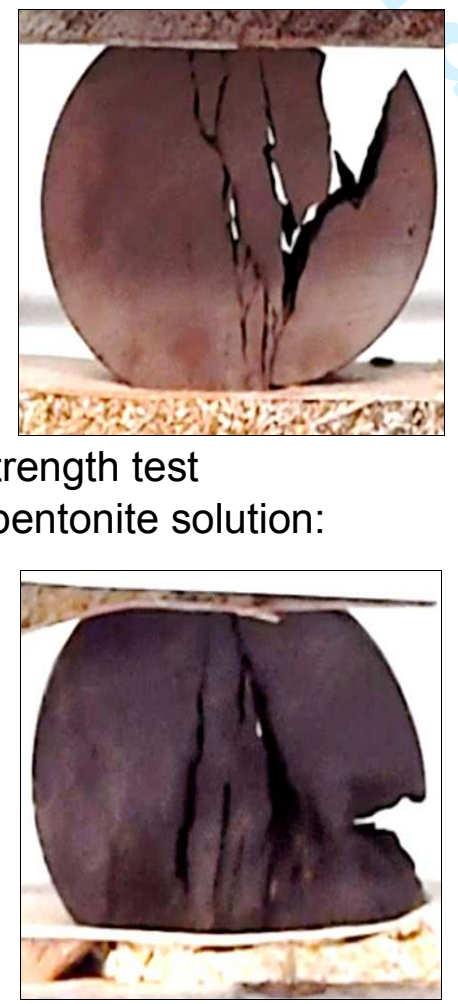

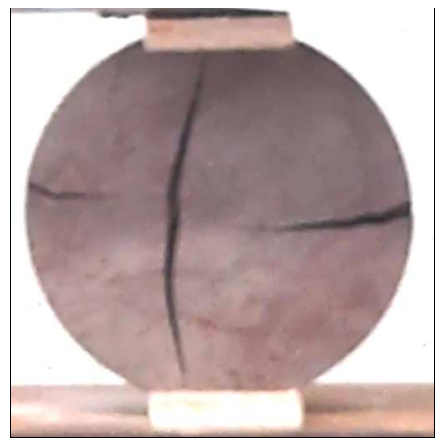

2) Horizontal strength test
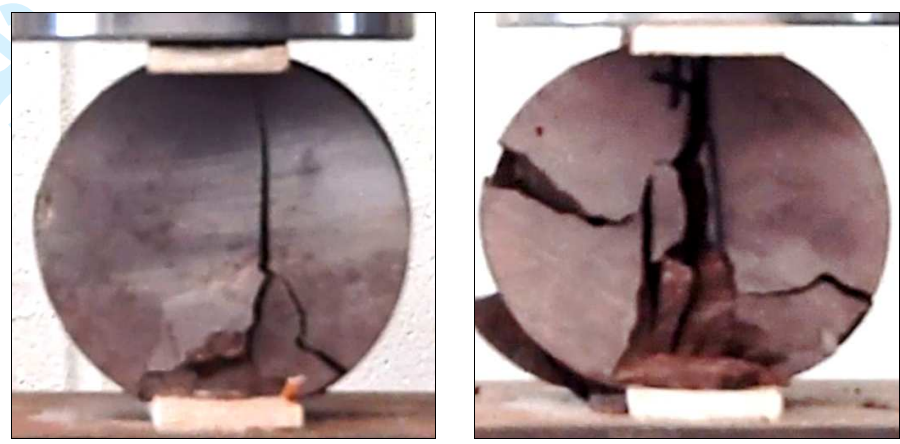

2) Horizontal strength test

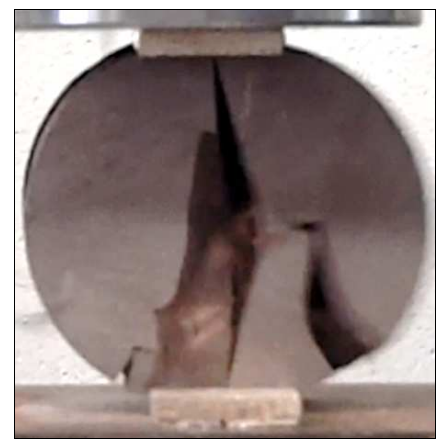

Fig. 6. Brazilian split test performed on: a) intact specimens and specimens soaked for hundred days in: b) water, c) polymer solution: and d) bentonite solution; 1) Vertical specimens, 2) Horizontal specimen, (these photos were captured from video records at failure). 
a) Intact specimen

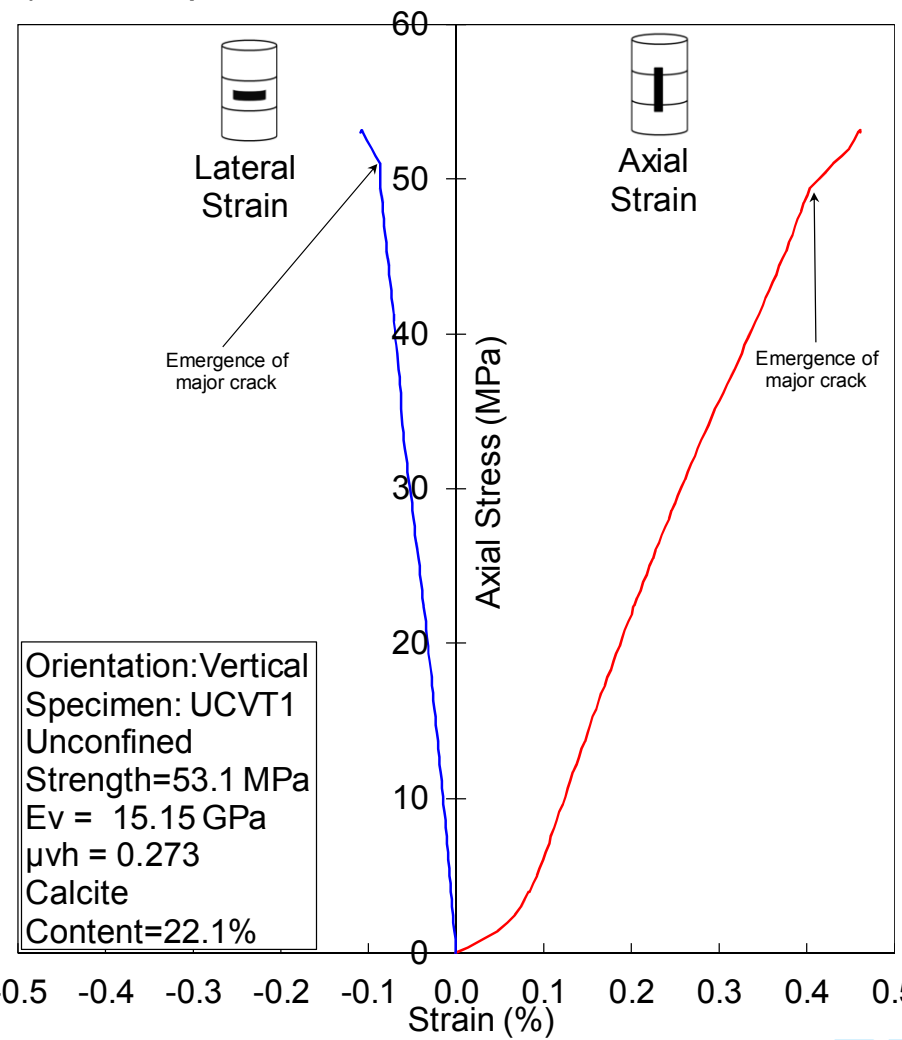

c) Specimen soaked in polymer solution

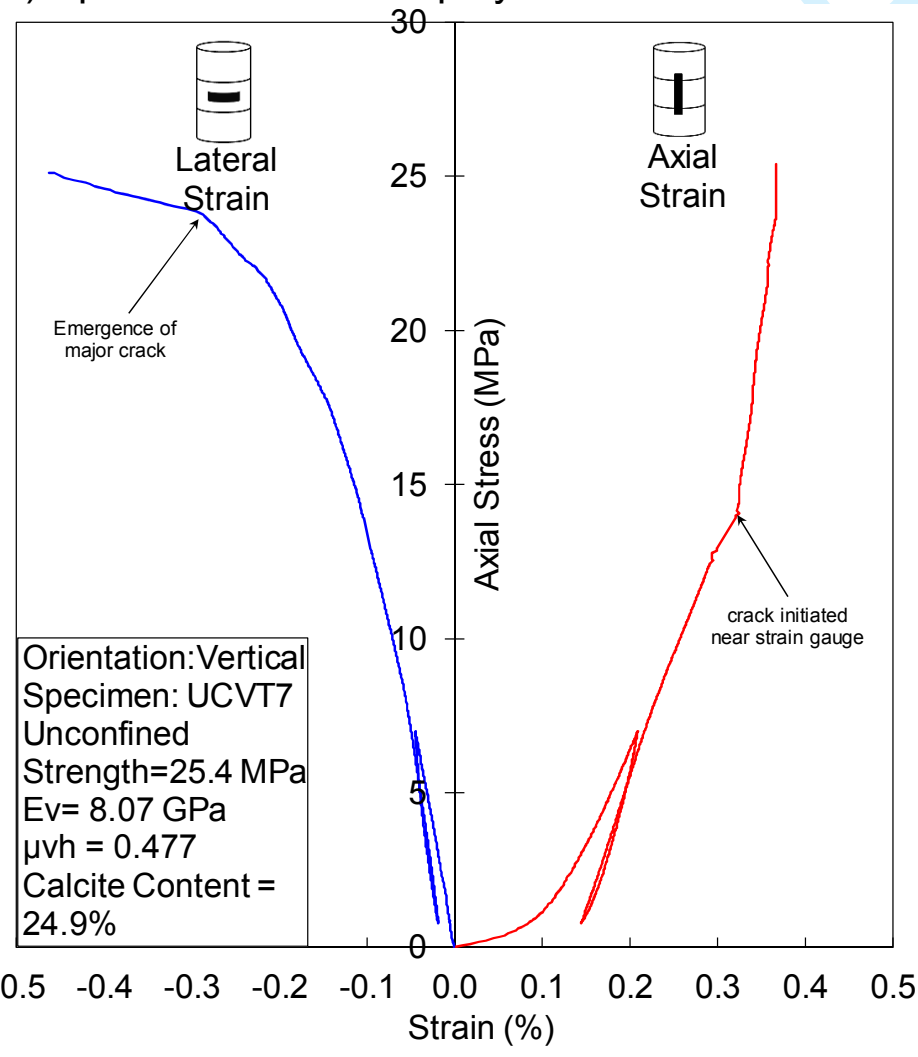

b) Specimen soaked in water

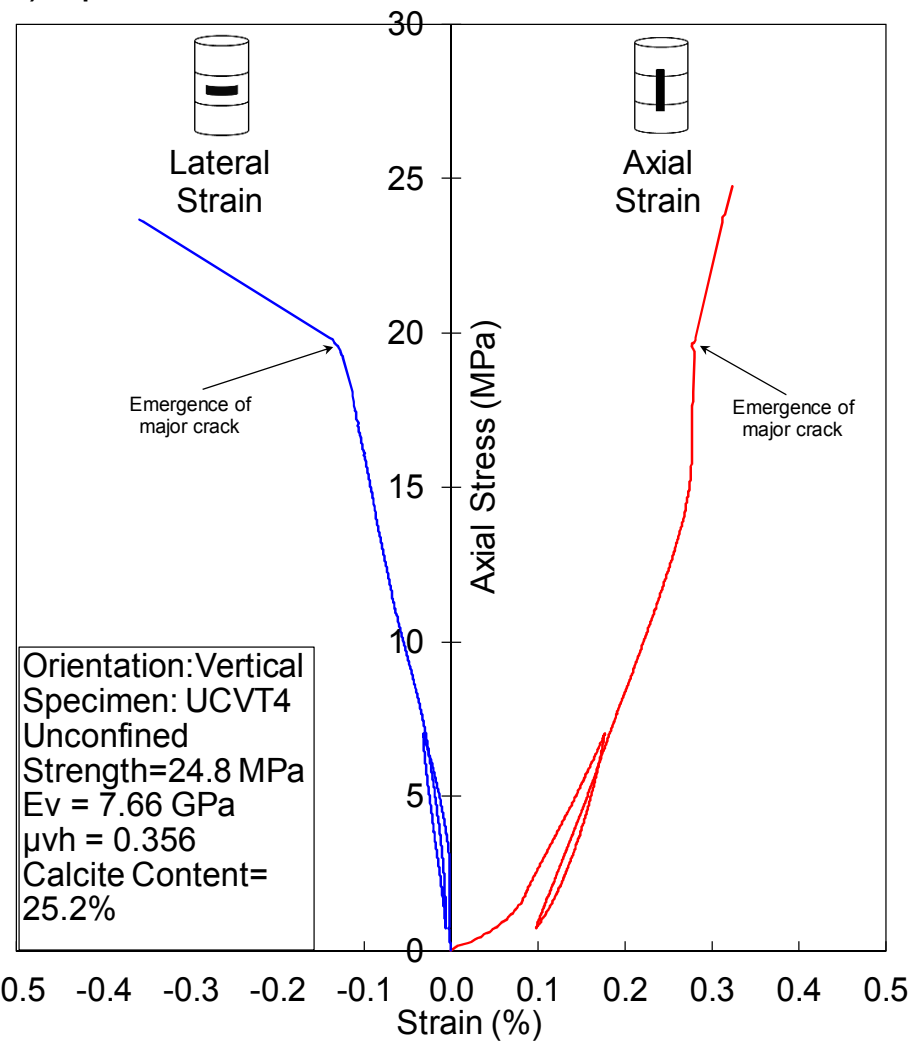

d) Specimen soaked in bentonite solution

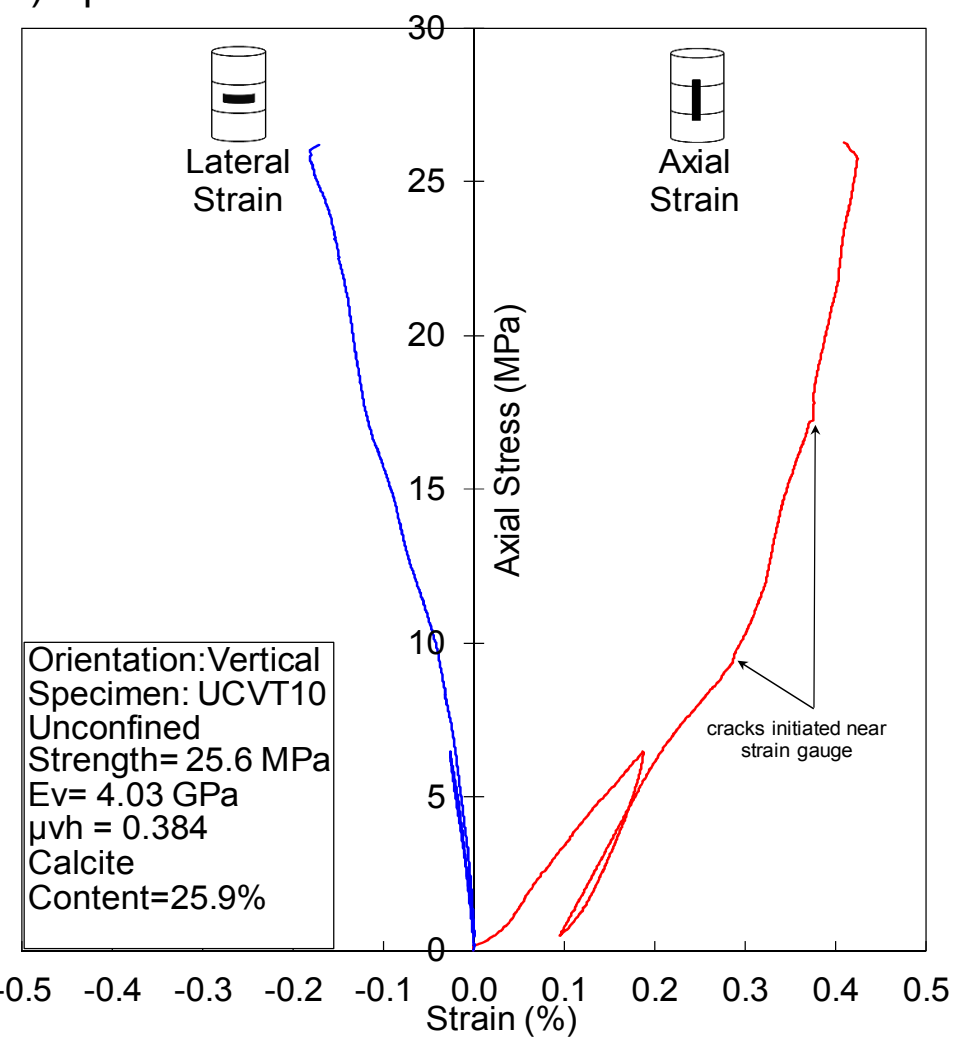

Fig.7. Results of unconfined compressive strength performed on vertically cored MQS specimens: a) intact specimen, specimens soaked for hundred days in: b) water, c) polymer solution and d) bentonite solution, respectively. 
a) Intact specimen

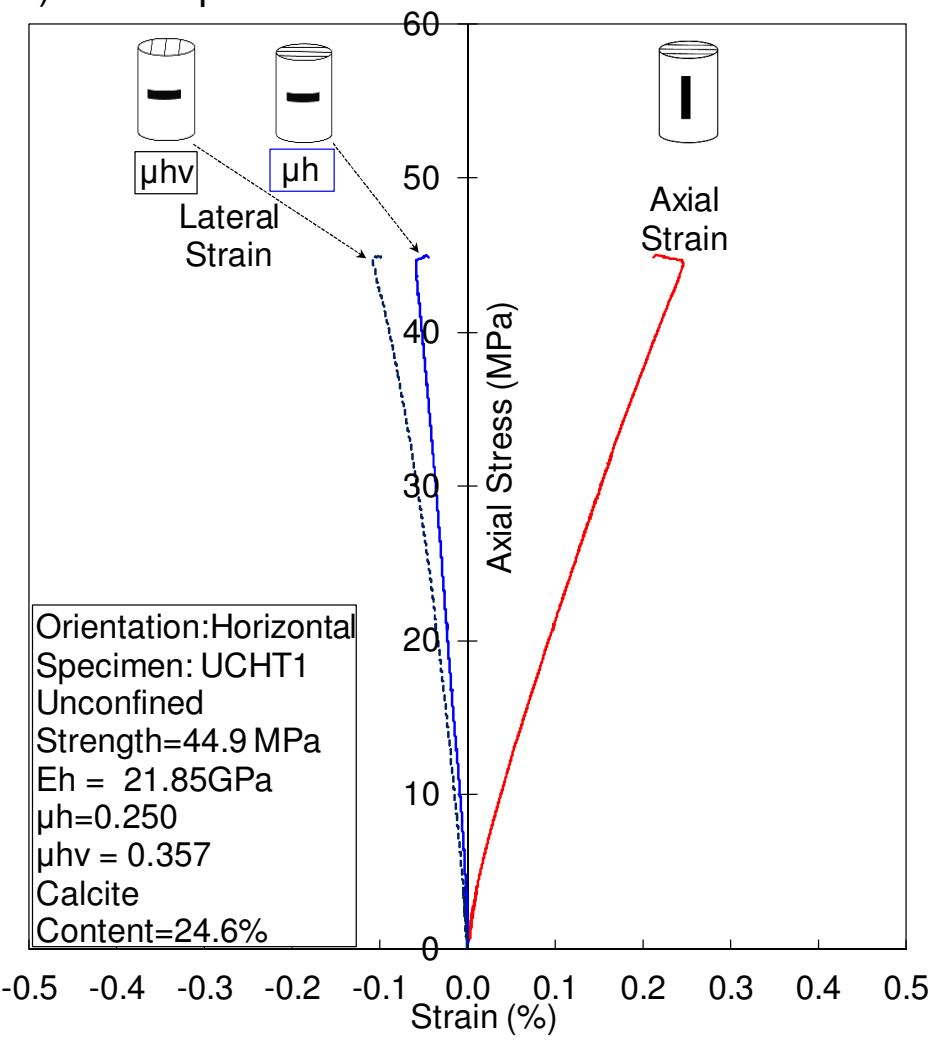

c) Specimen soaked in polymer solution

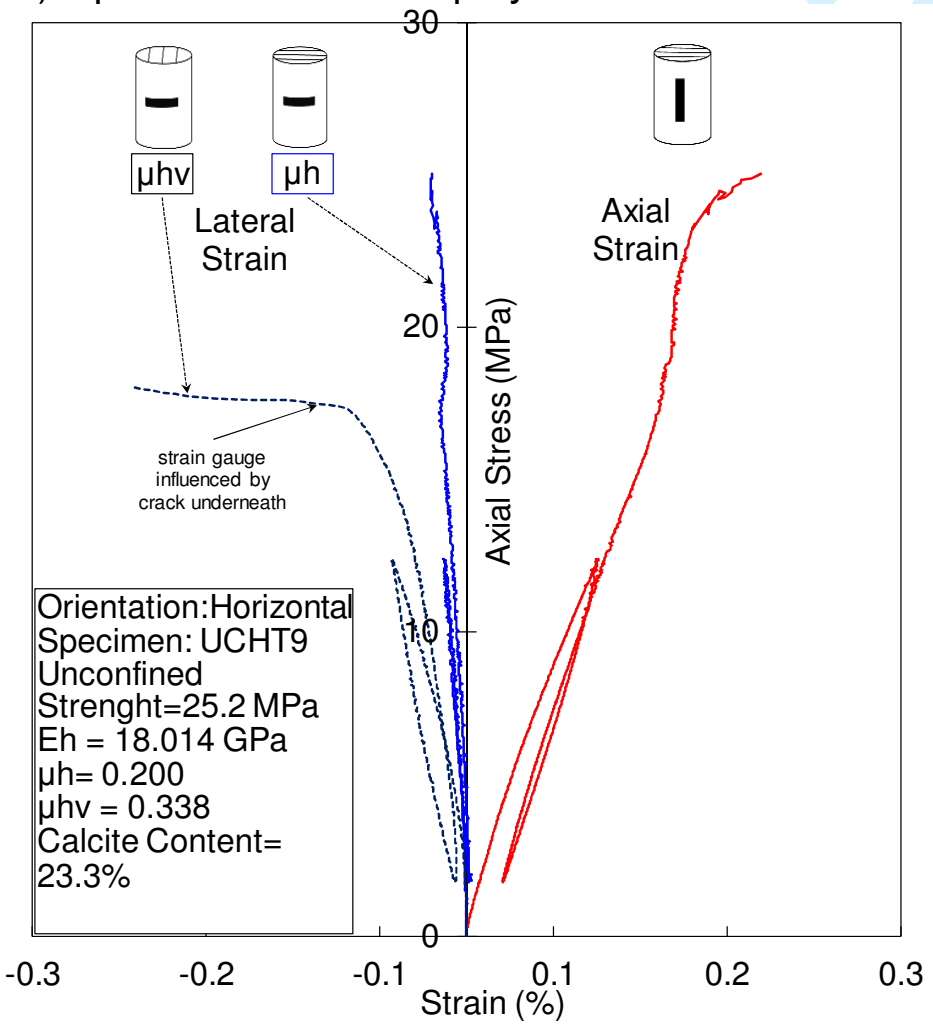

b) Specimen soaked in water

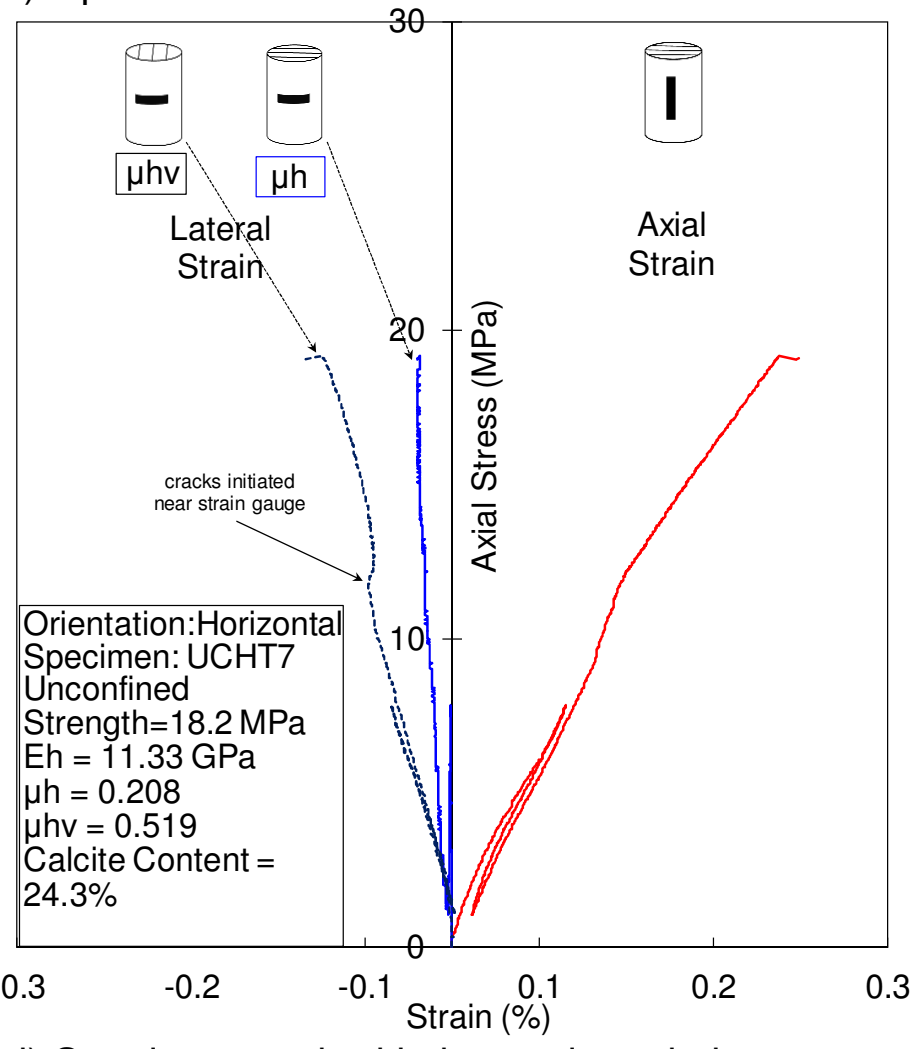

d) Specimen soaked in bentonite solution

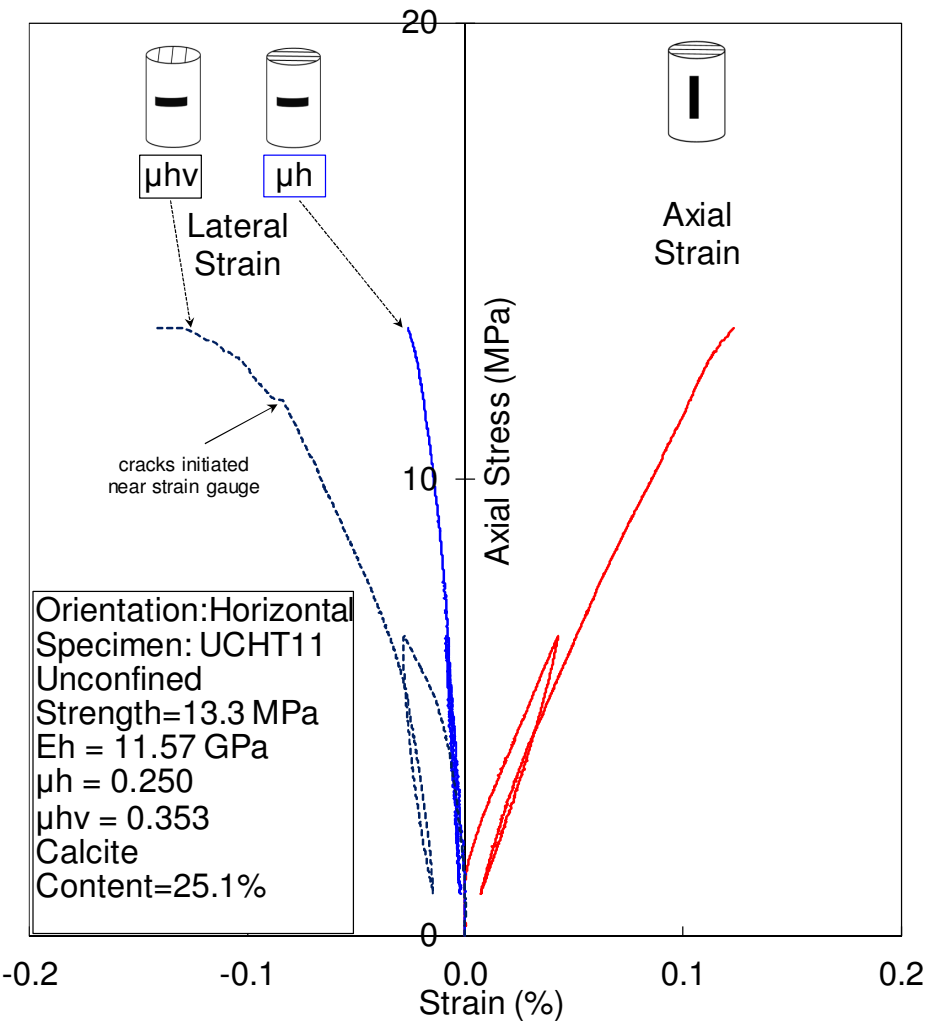

Fig. 8. Results of unconfined compressive strength performed on horizontally cored MQS specimens: a) intact specimen, specimens soaked for hundred days in: b) water, c) polymer solution and d) bentonite solution, respectively. 


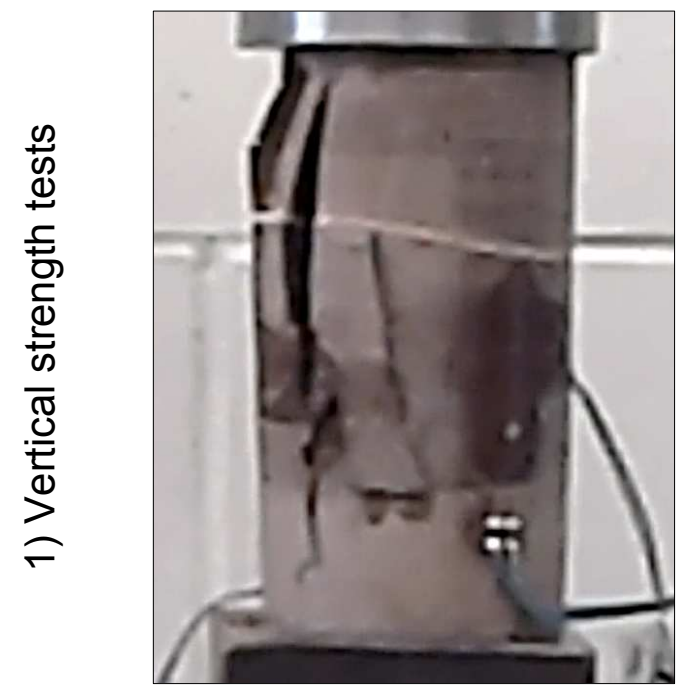

a) Intact specimens:

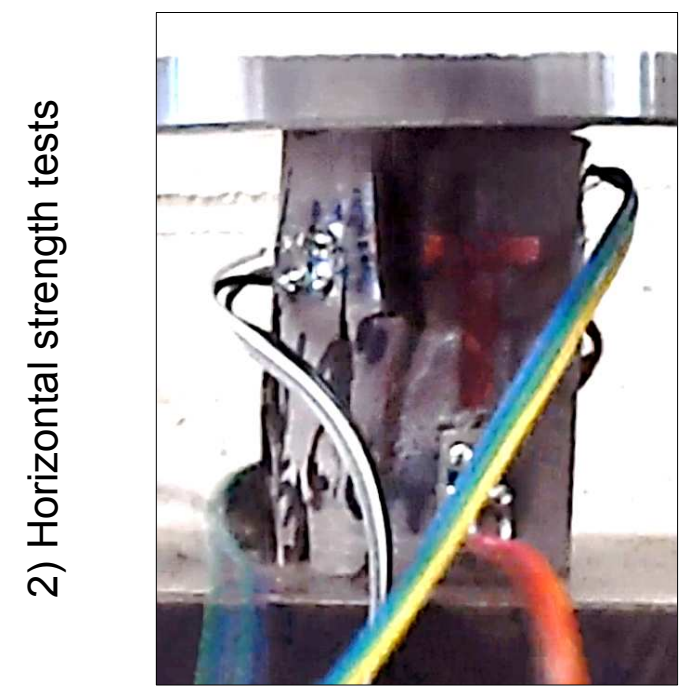

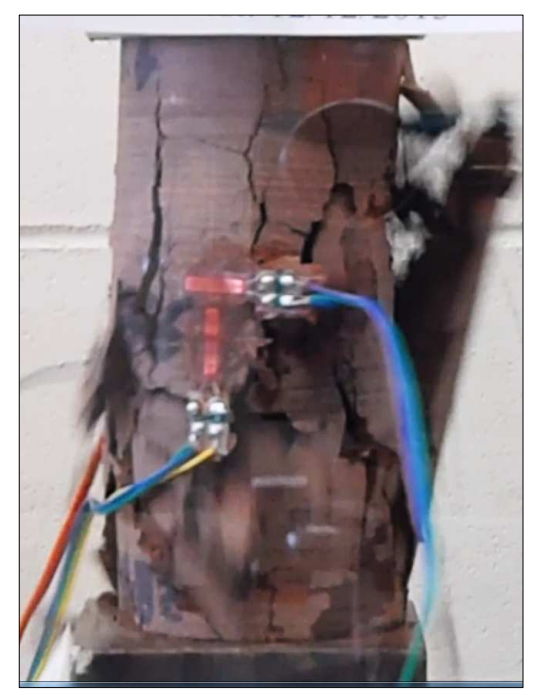

b) Specimens soaked in water:

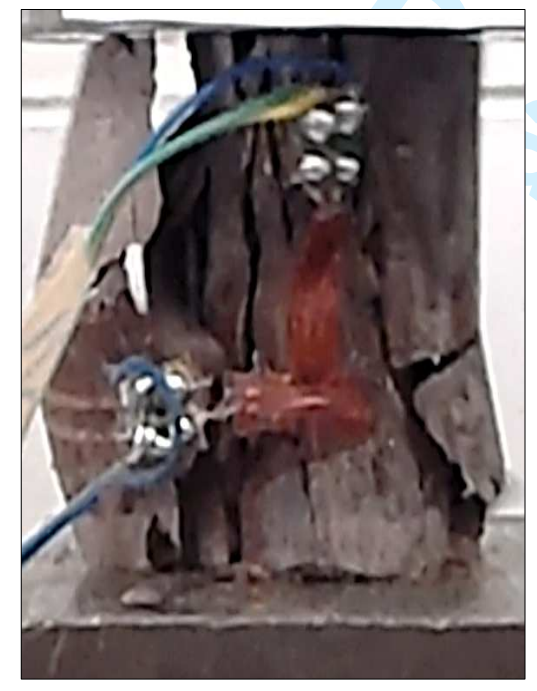

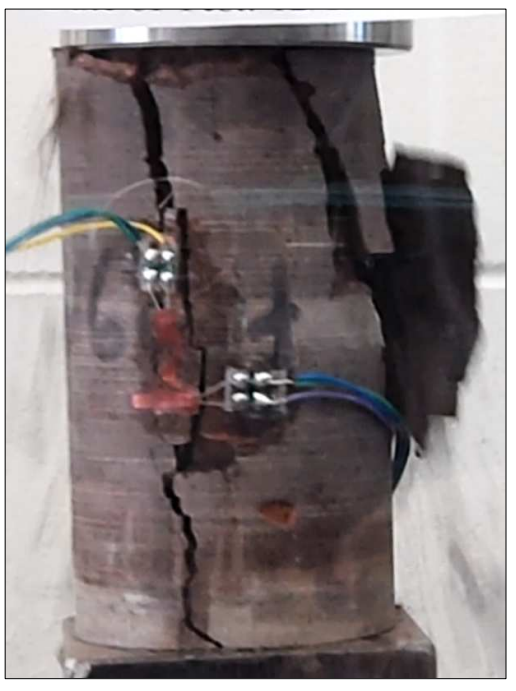

c) Specimens soaked in polymer solution:

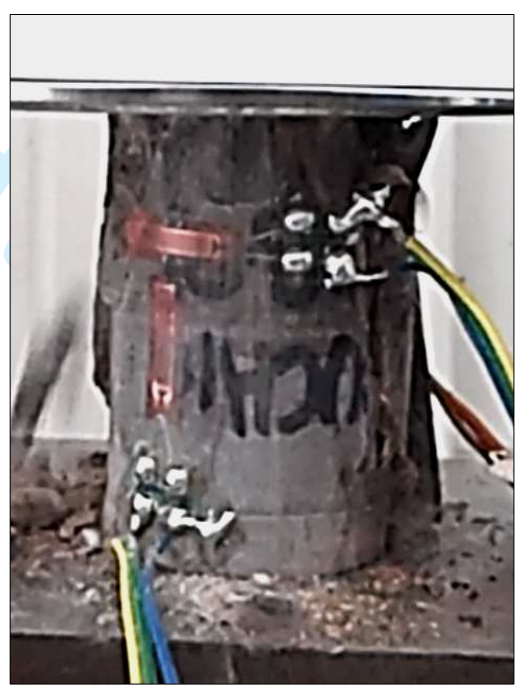

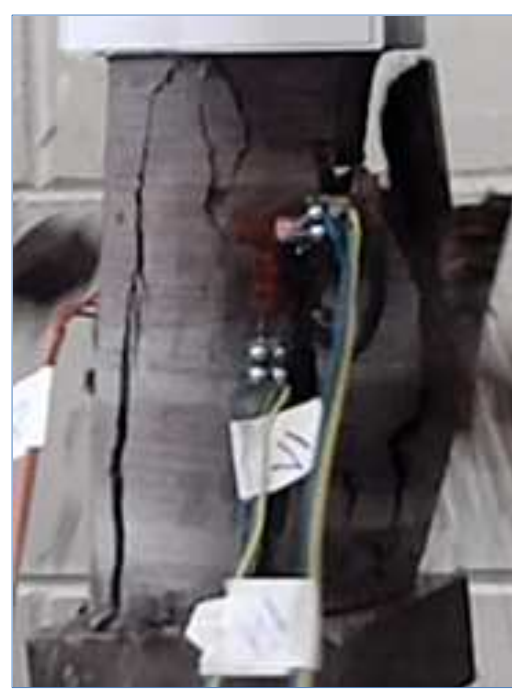

d) Specimens soaked in bentonite solution:

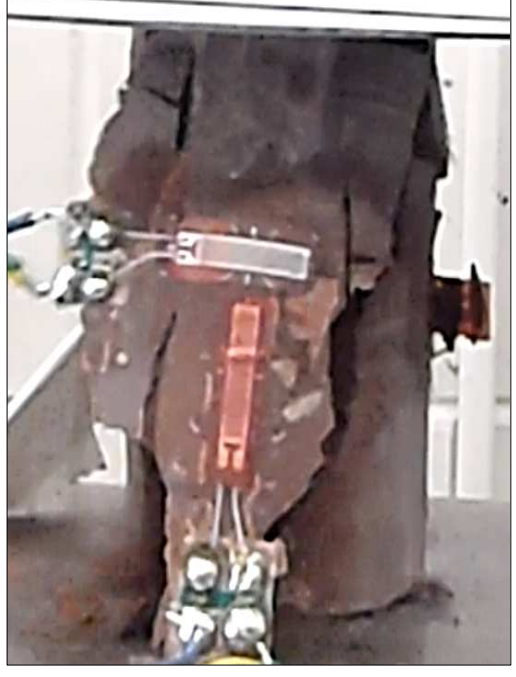

Fig. 9. Unconfined compressive strength test performed on: a) intact specimens and specimens soaked for hundred days in: b) water, c) polymer solution: and d) bentonite solution; 1) Vertical specimens, 2) Horizontal specimen, (these photos were captured from video records at failure). 
a) Intact specimen:

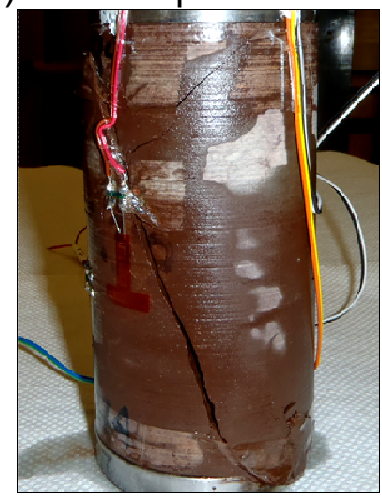

1) Vertical strength test

b) Specimen soaked in water:
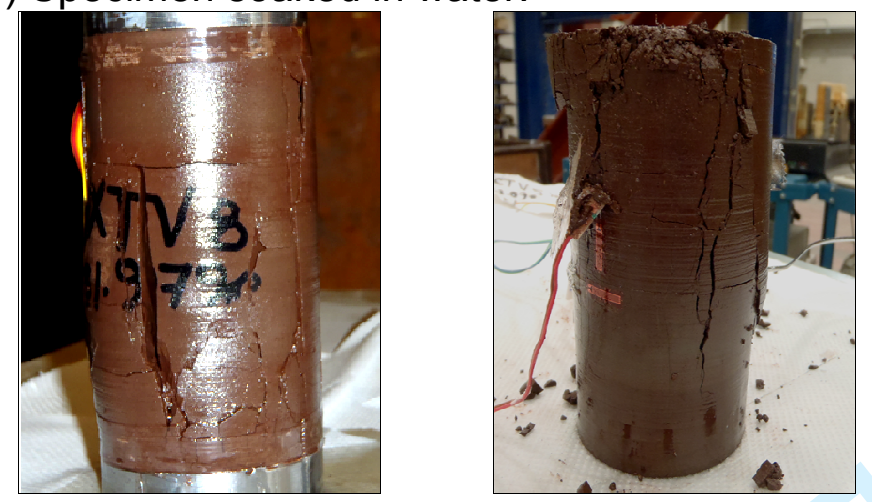

1) Vertical strength test

c) Specimen soaked in polymer solution:
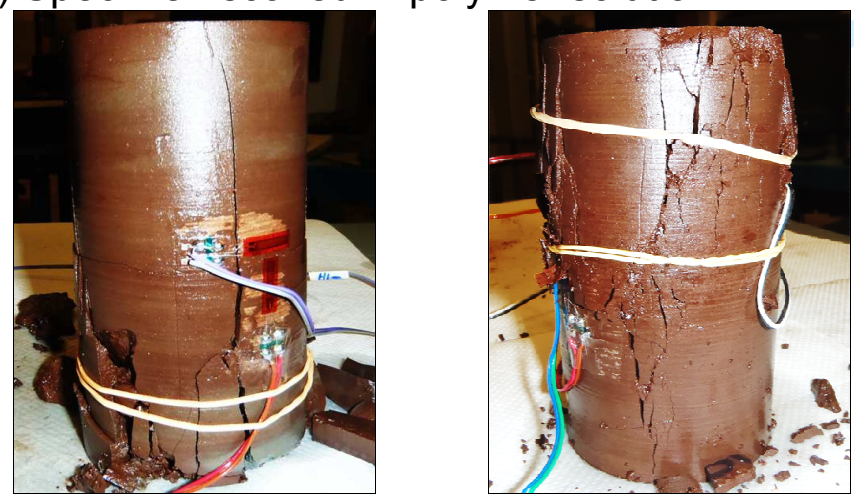

1) Vertical strength test

d) Specimen soaked in bentonite solution:
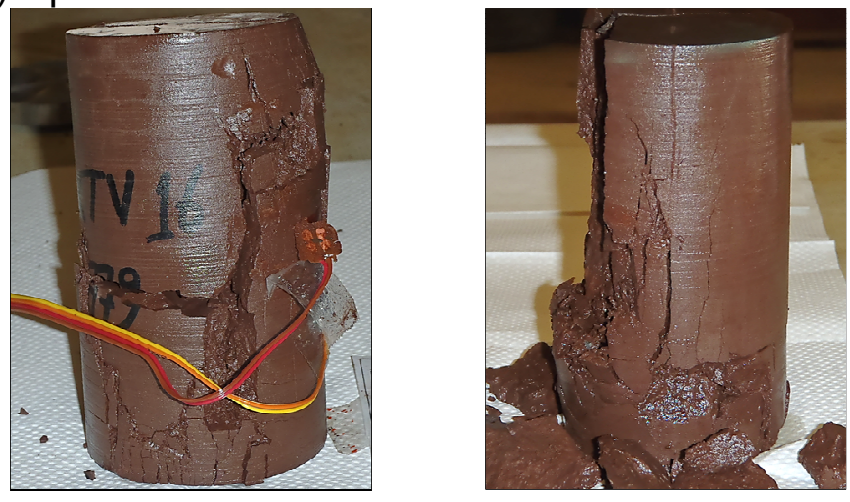

1) Vertical strength test
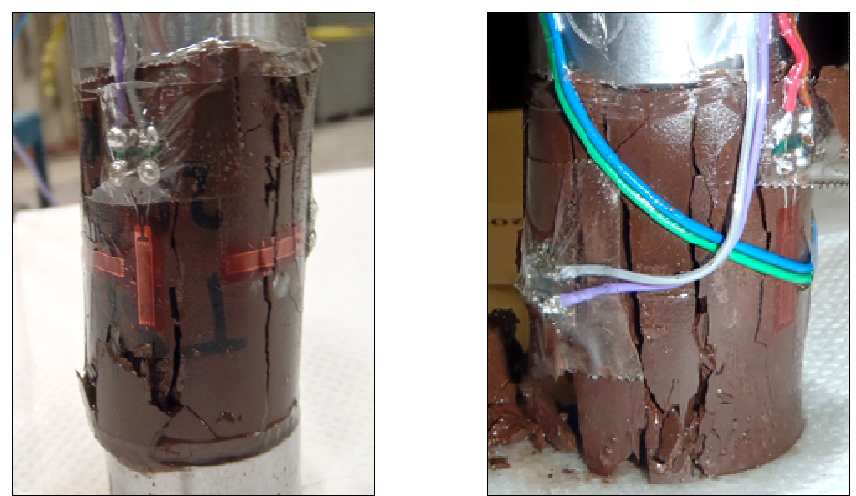

2) Horizontal strength test
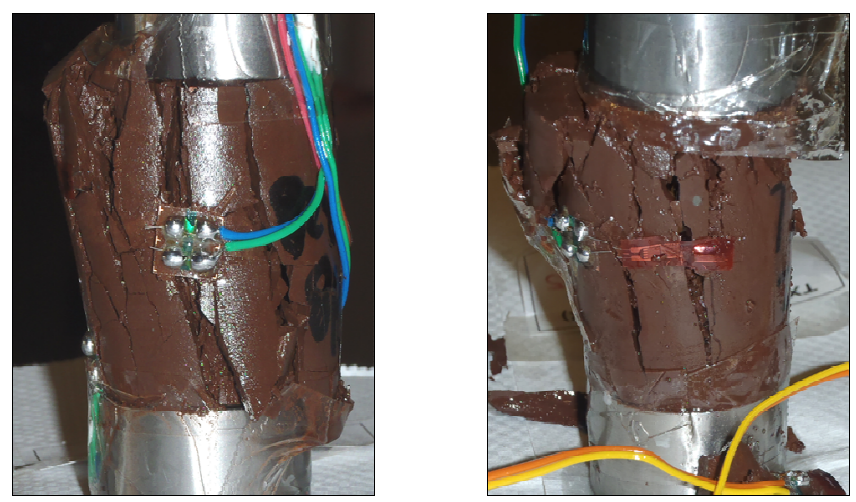

2) Horizontal strength test
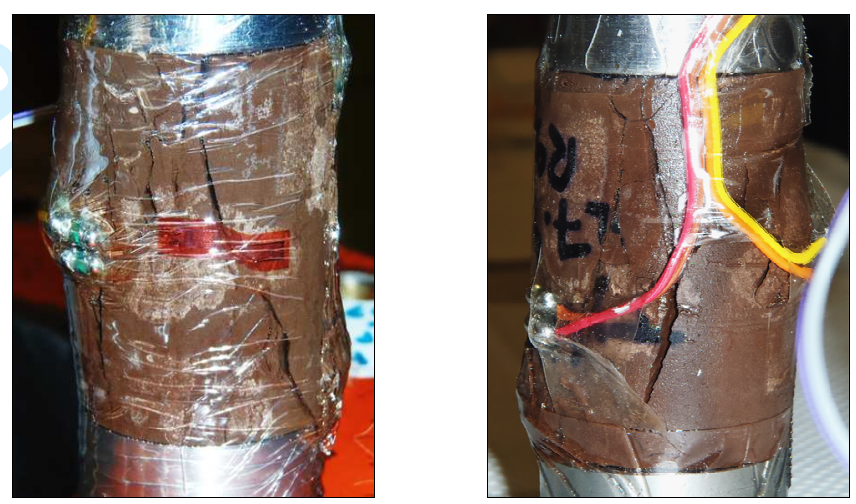

2) Horizontal strength test
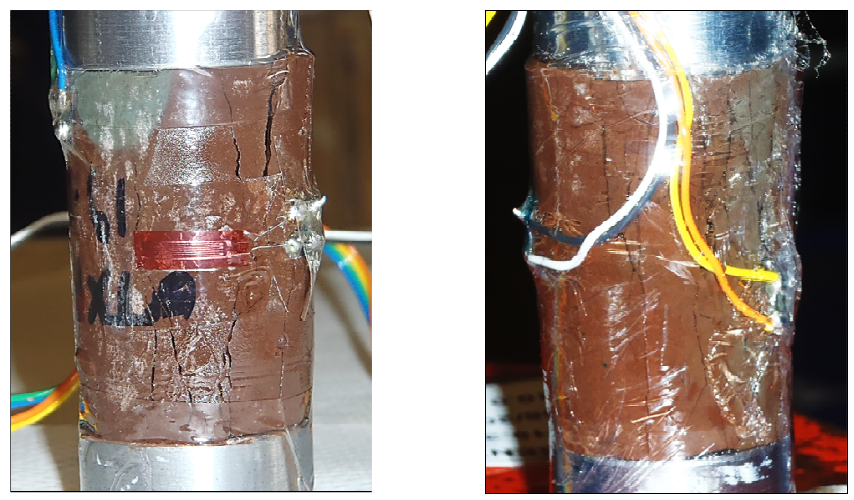

2) Horizontal strength test

Fig. 10. Triaxial compressive strength test performed on: a) intact specimens and specimens soaked for hundred

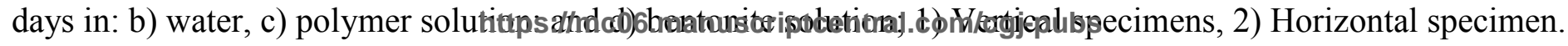


a) Intact specimen

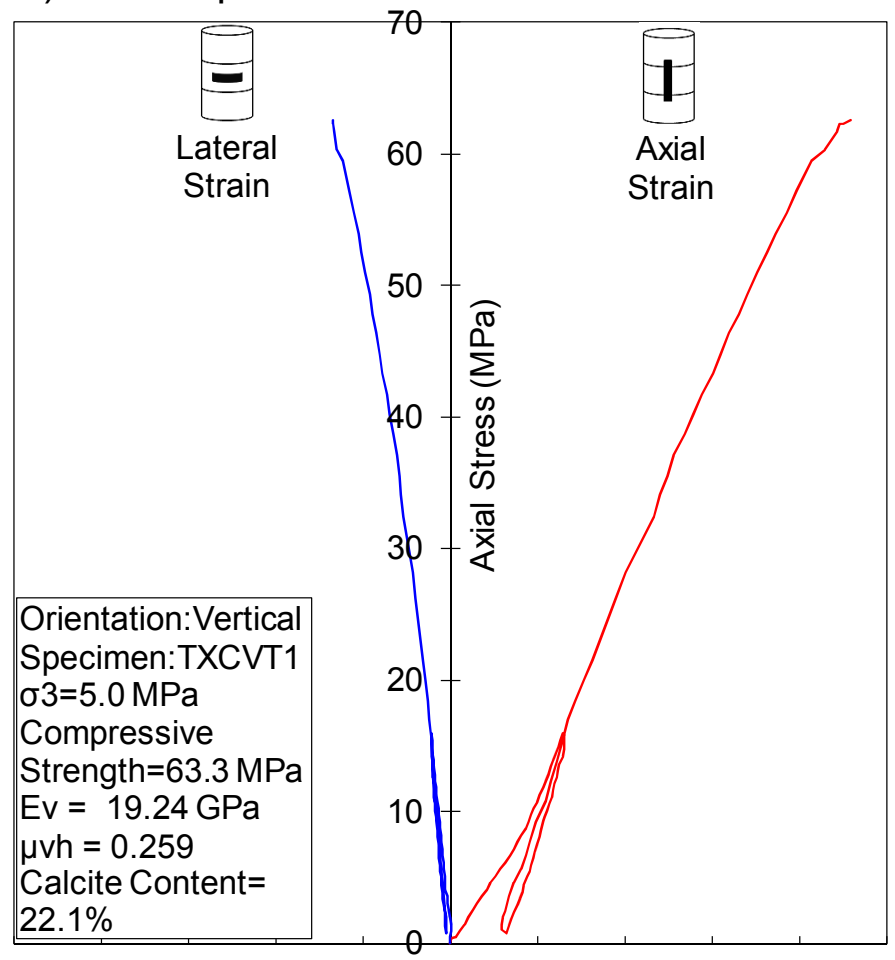

$\begin{array}{lllllll}-0.5 & -0.4 & -0.3 & -0.2 & -0.1 & 0.0 & 0.1 \\ \text { Strain }(\%)\end{array}$

c) Specimen soaked in polymer solution

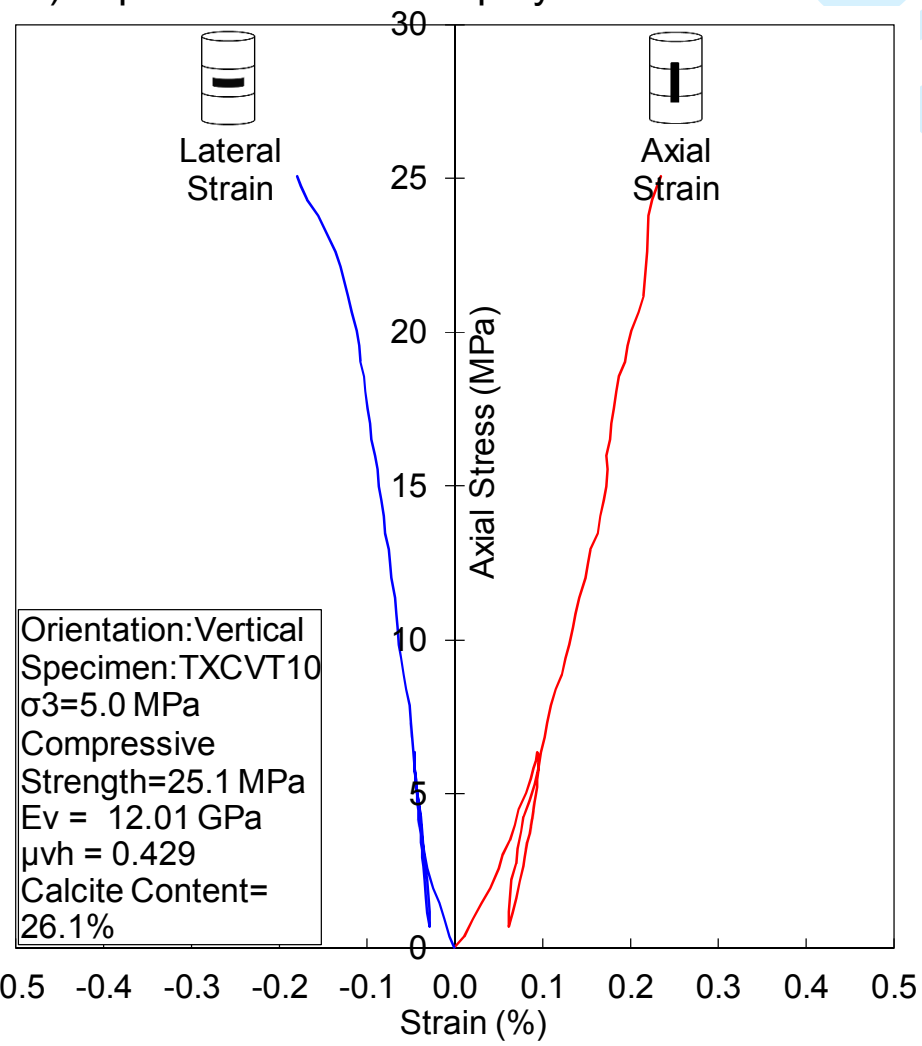

b) Specimen soaked in water

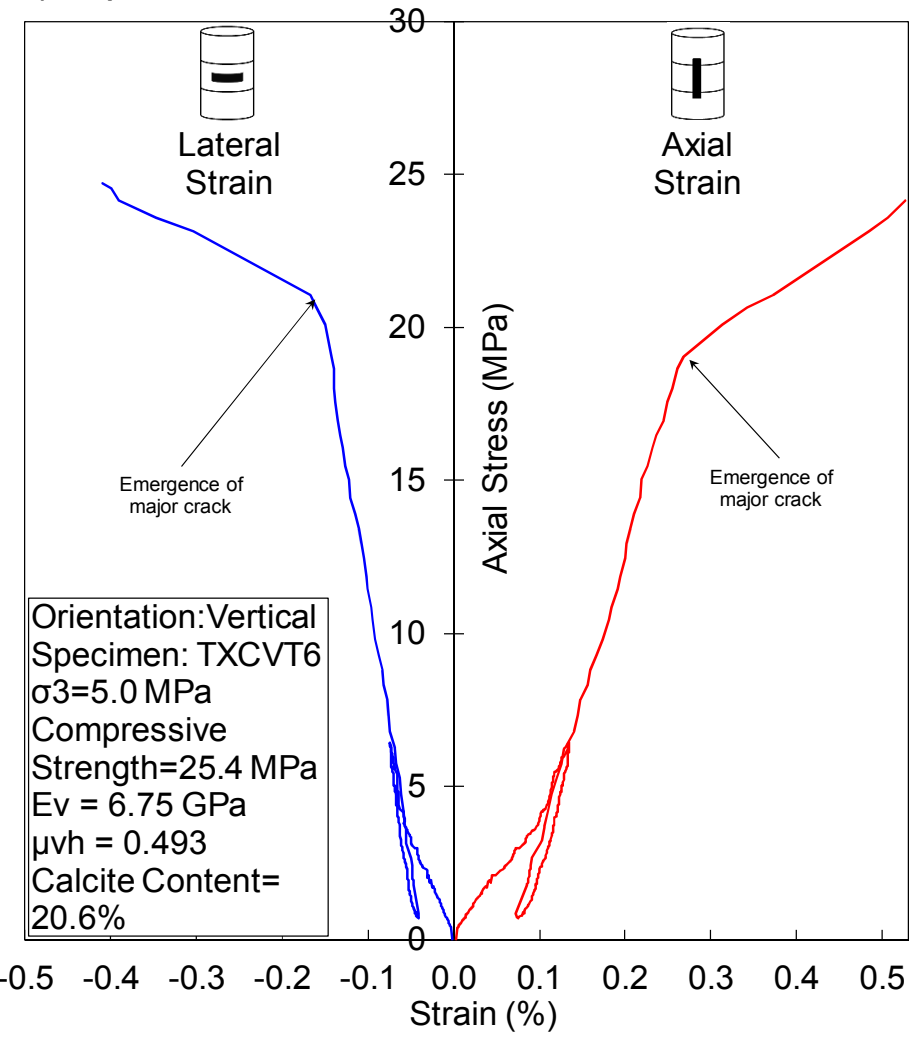

d) Specimen soaked in bentonite solution

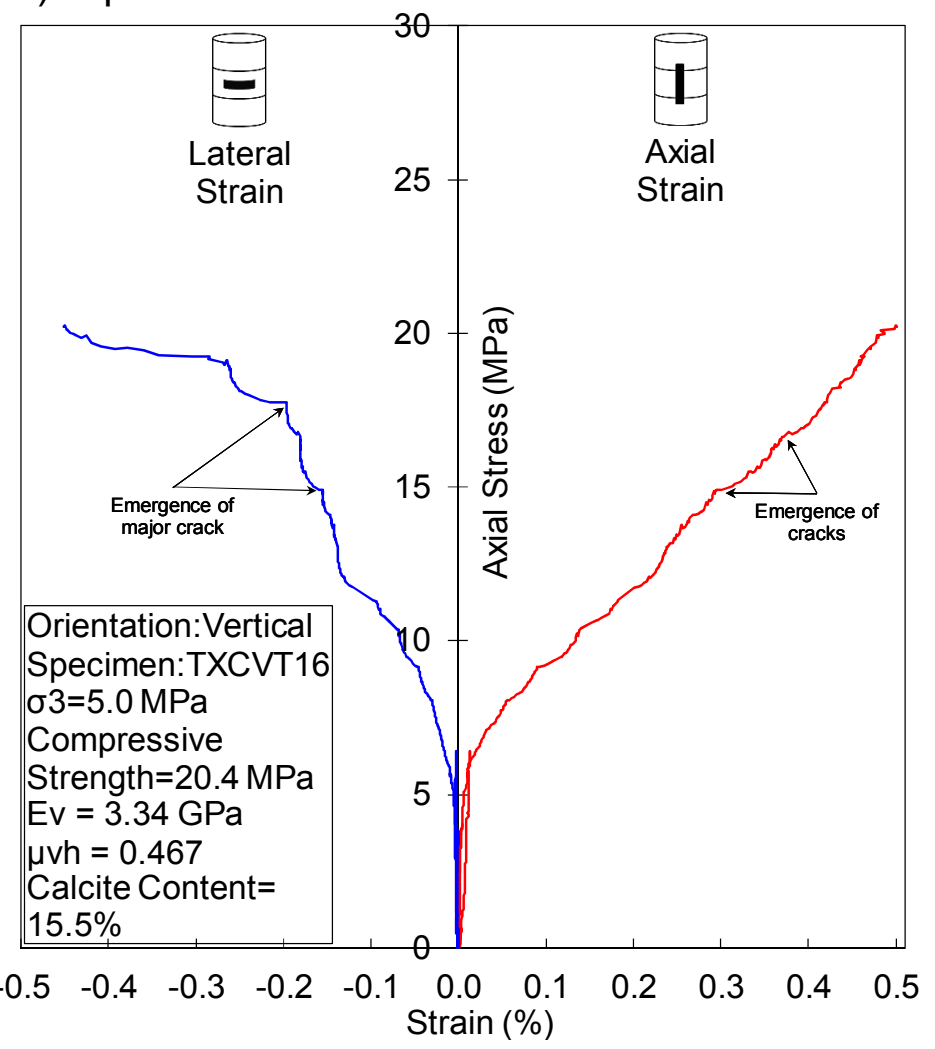

Fig. 11. Results of triaxial compression strength performed on vertically cored MQS specimens at $\sigma 3=5.0 \mathrm{MPa}$ : a) intact specimen, specimens soaked for hundred days in: b) water, c) polymer solution and d) bentonite solution, respectively. 
a) Intact specimen

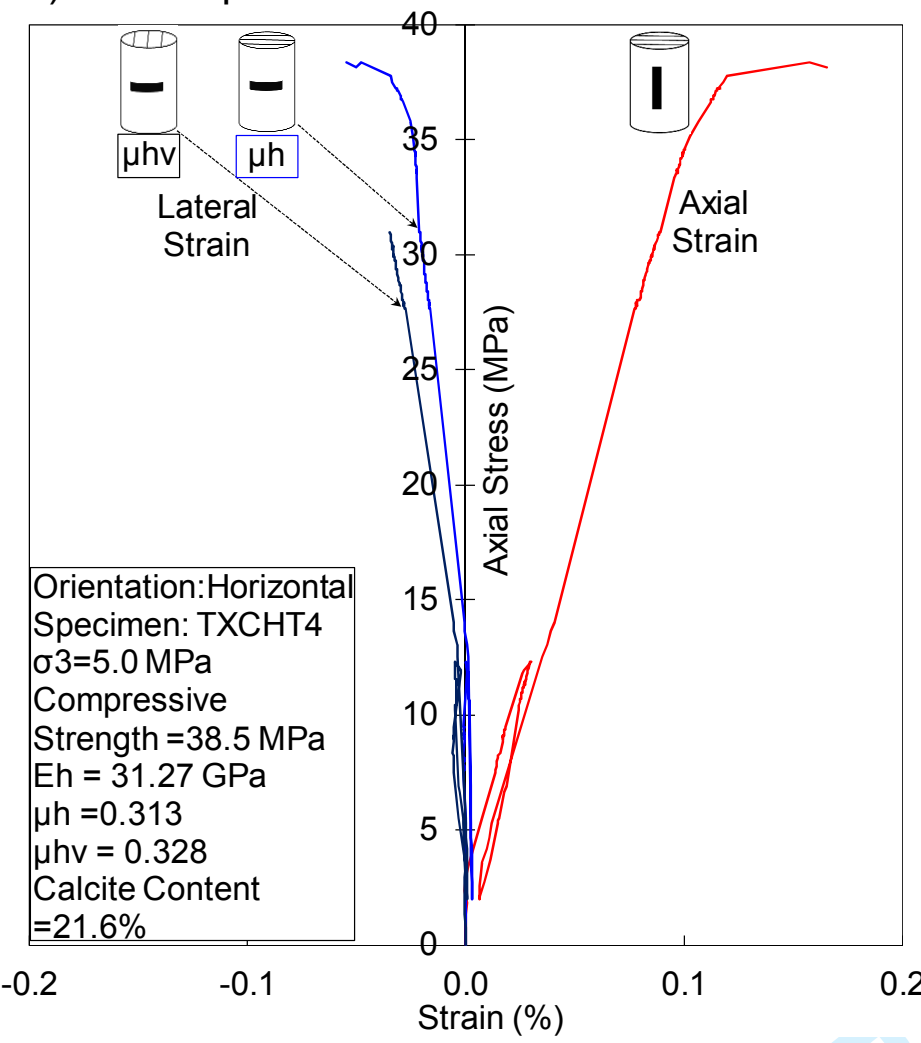

C) Specimen soaked in polymer solution

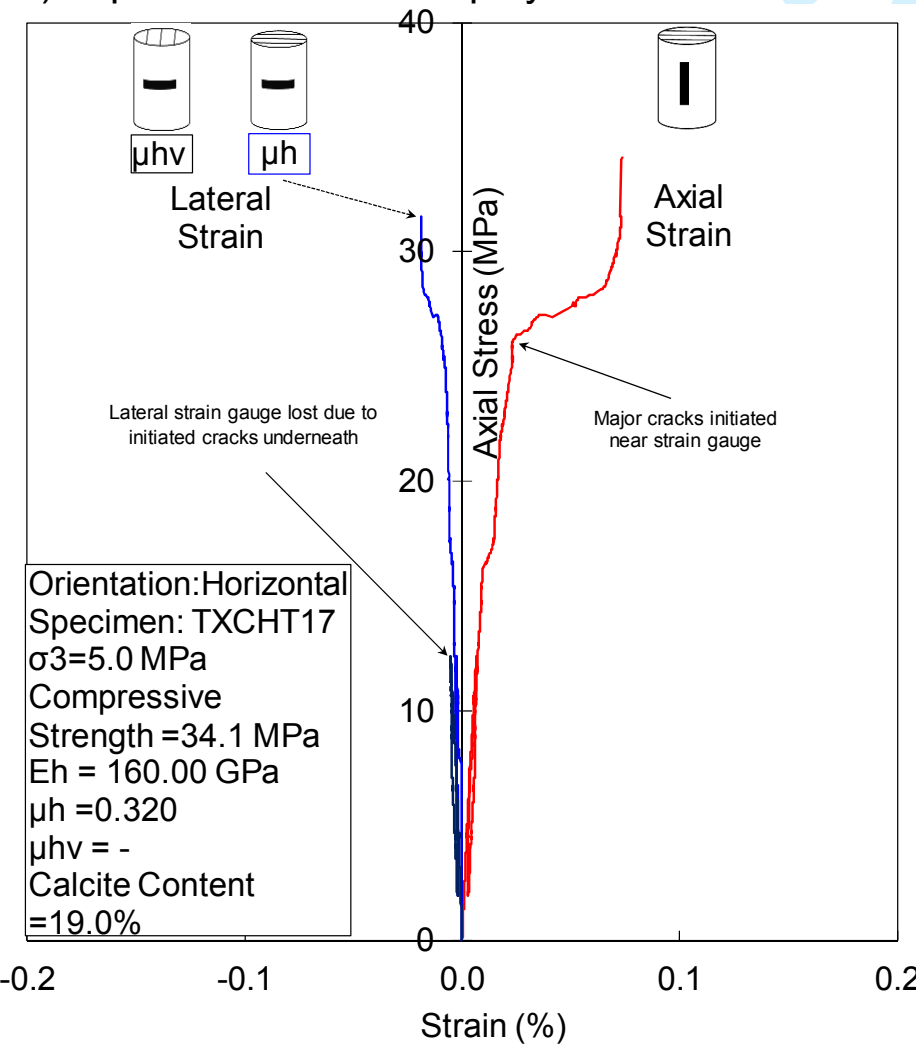

b) Specimen soaked in water

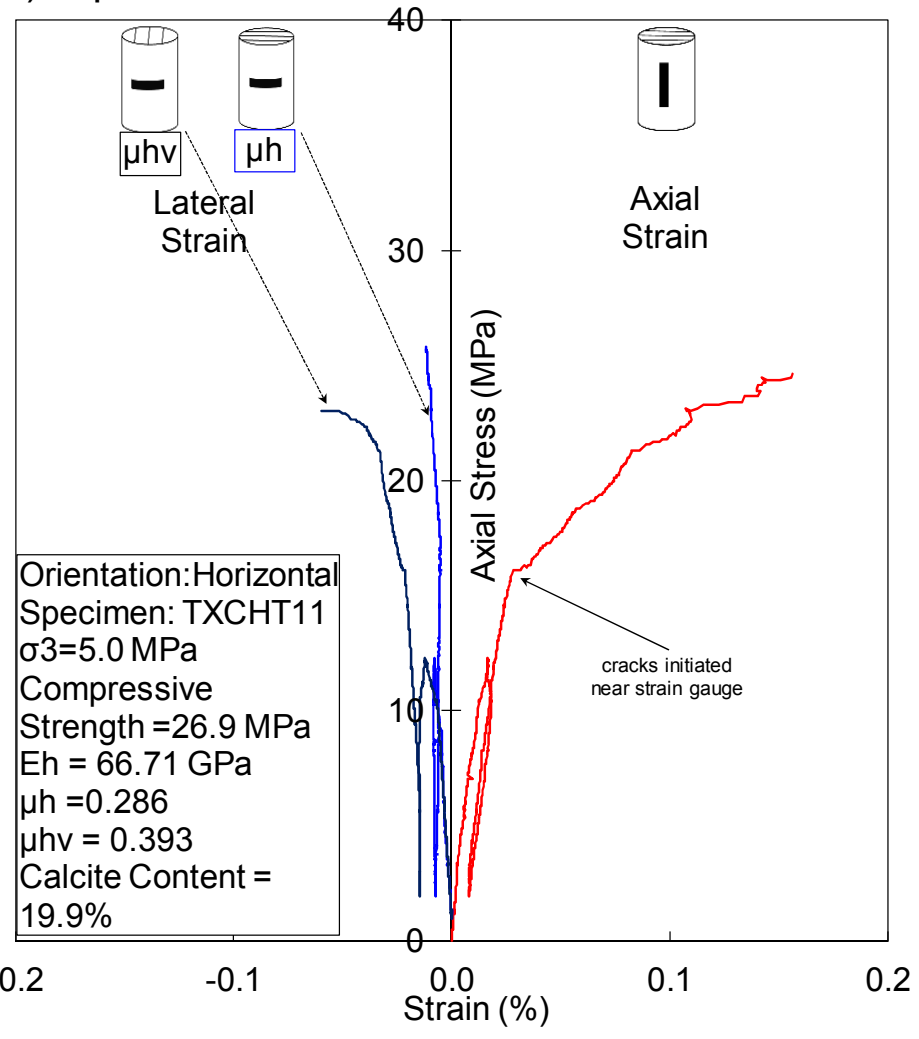

d) Specimen soaked in bentonite solution

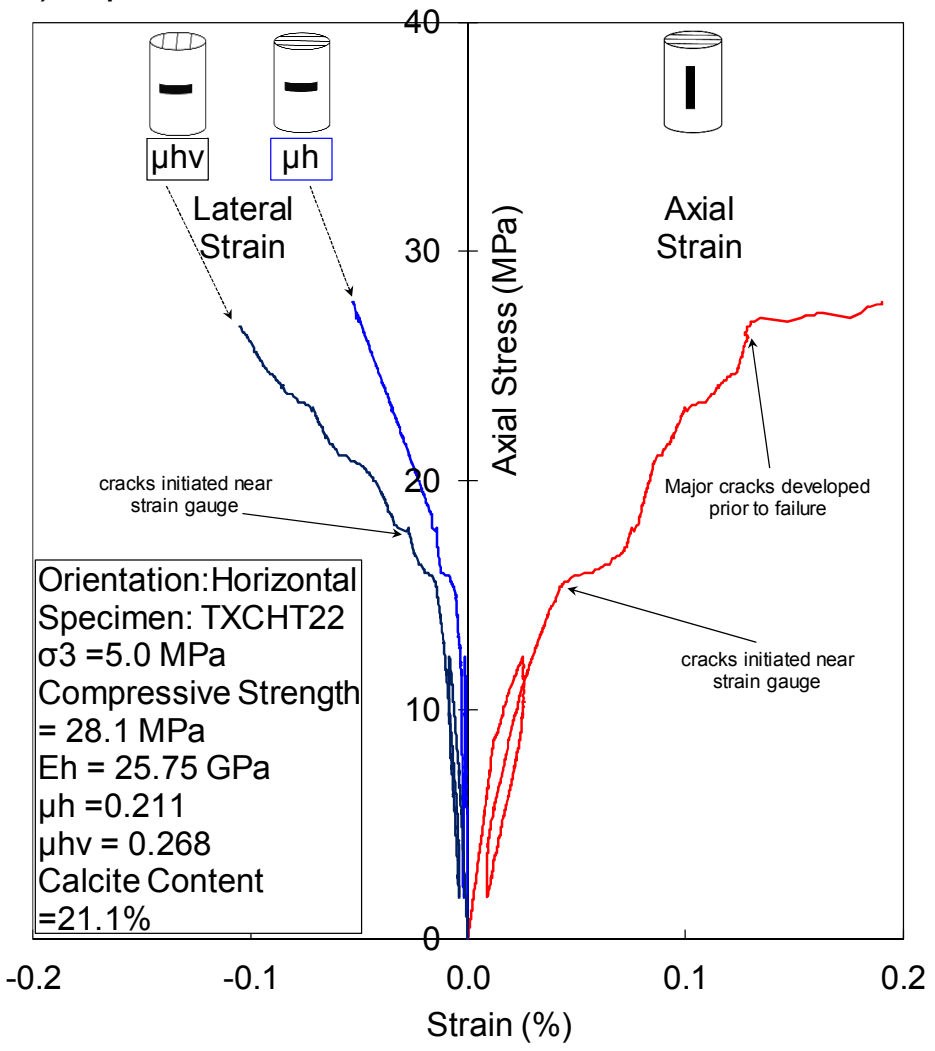

Fig. 12. Results of triaxial compression strength performed on horizontally cored MQS specimens at $\sigma 3=5.0$ MPa: a) intact specimen, specimens soaked for hundred days in: b) water, c) polymer solution and d) bentonite solution, respectively. 
a) Strength envelopes of MQS in the vertical direction Canadian Geotegghnsigal Jghthnal envelopes of MQS in the horizontal direction

(Principal Stresses)

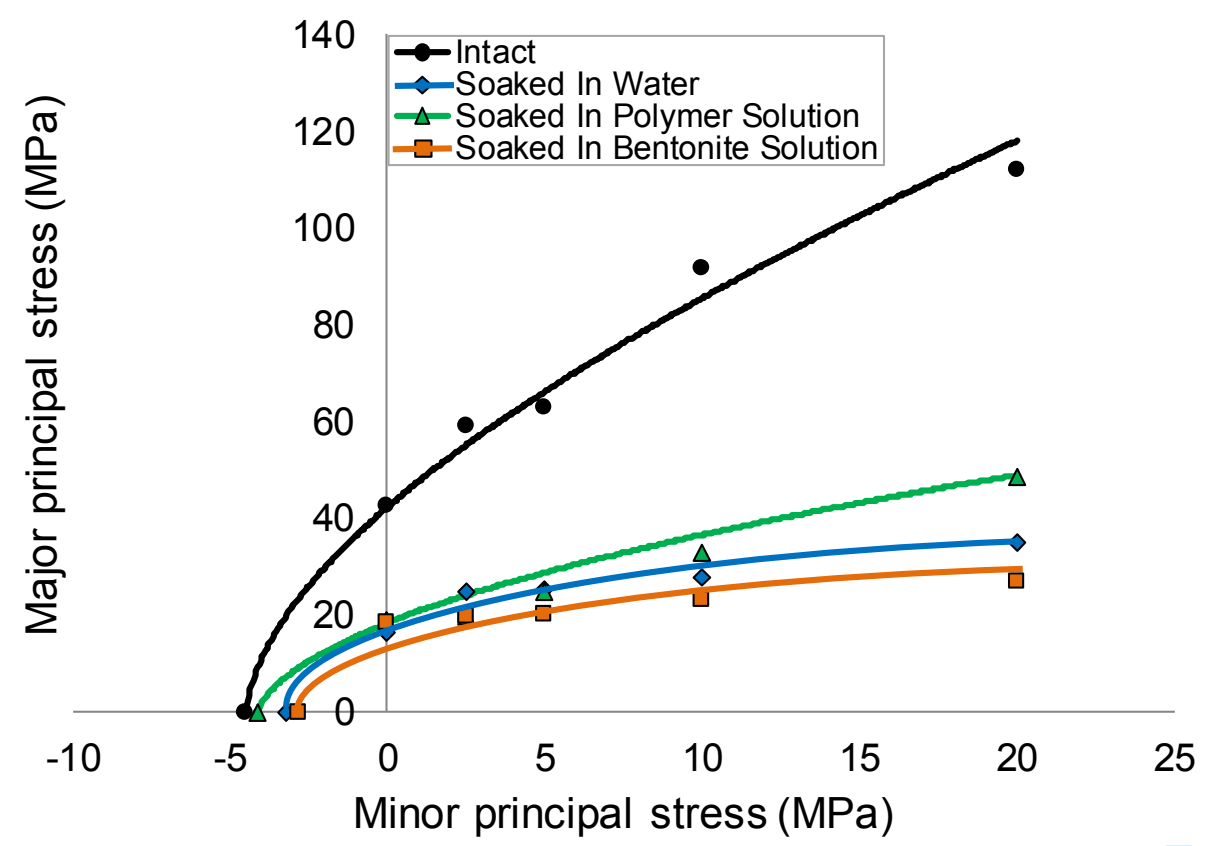

c) Strength envelopes of MQS in the vertical direction

(Normal Stress Versus Shear Stress)

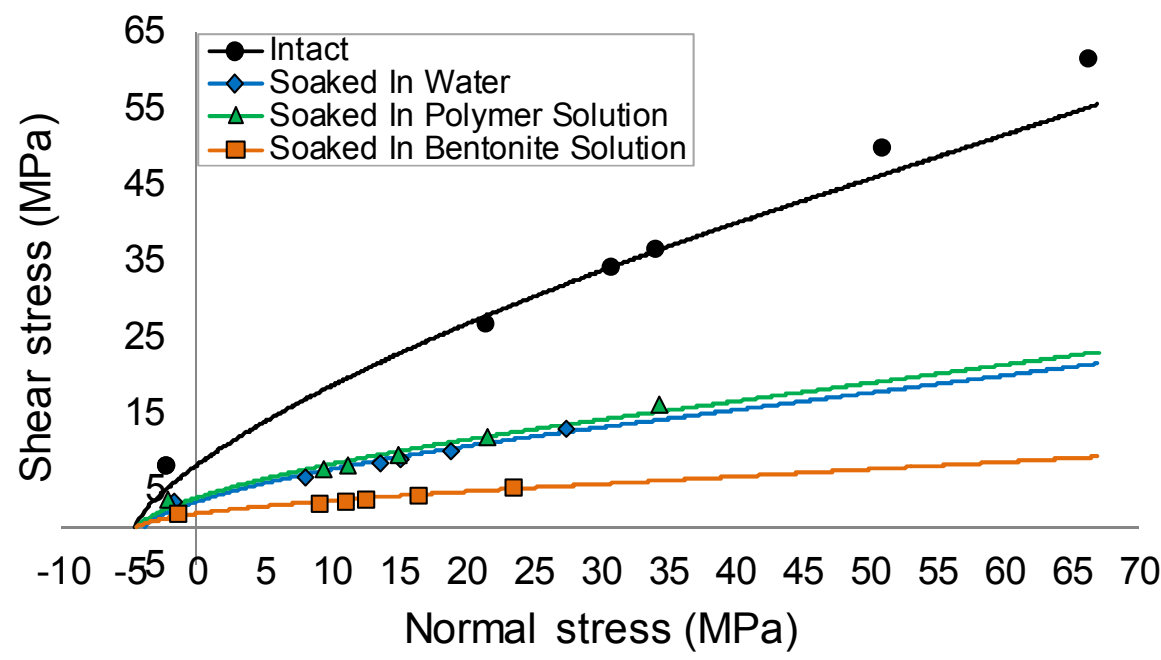

(Principal Stresses)

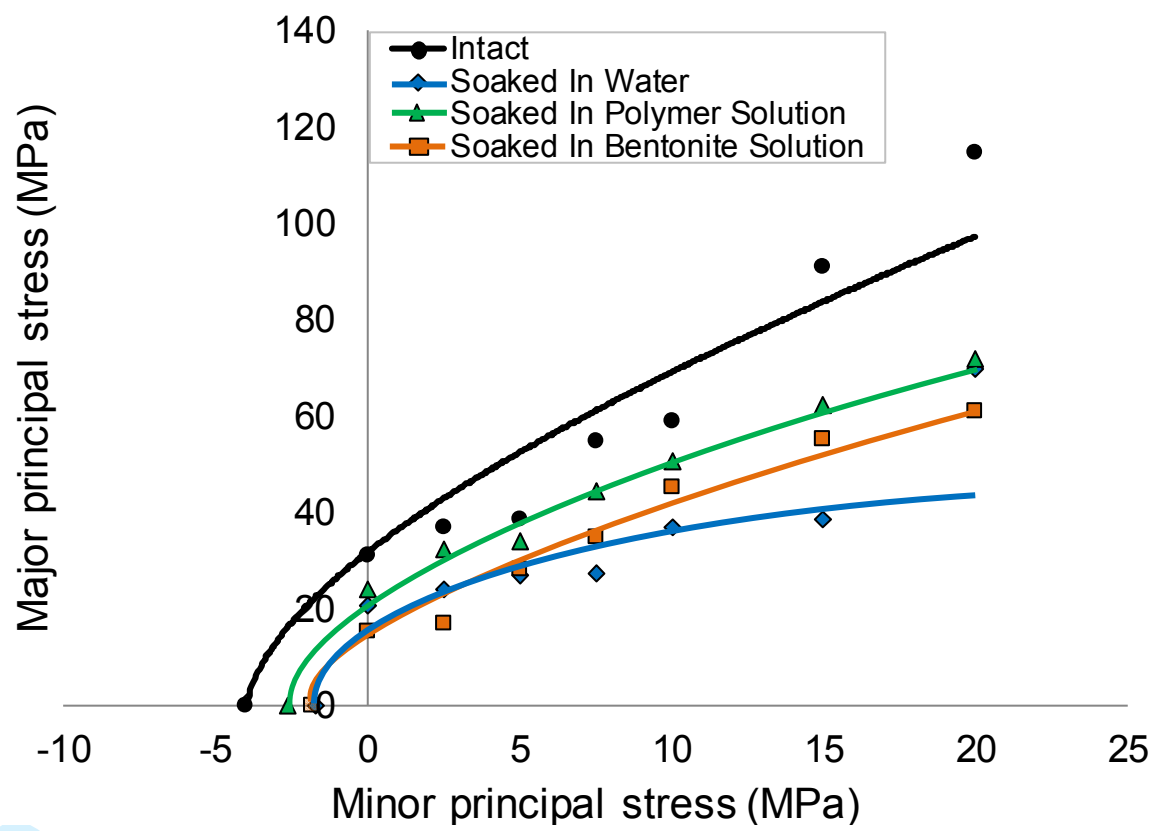

d) Strength envelopes of MQS in the horizontal direction (Normal Stress Versus Shear Stress)

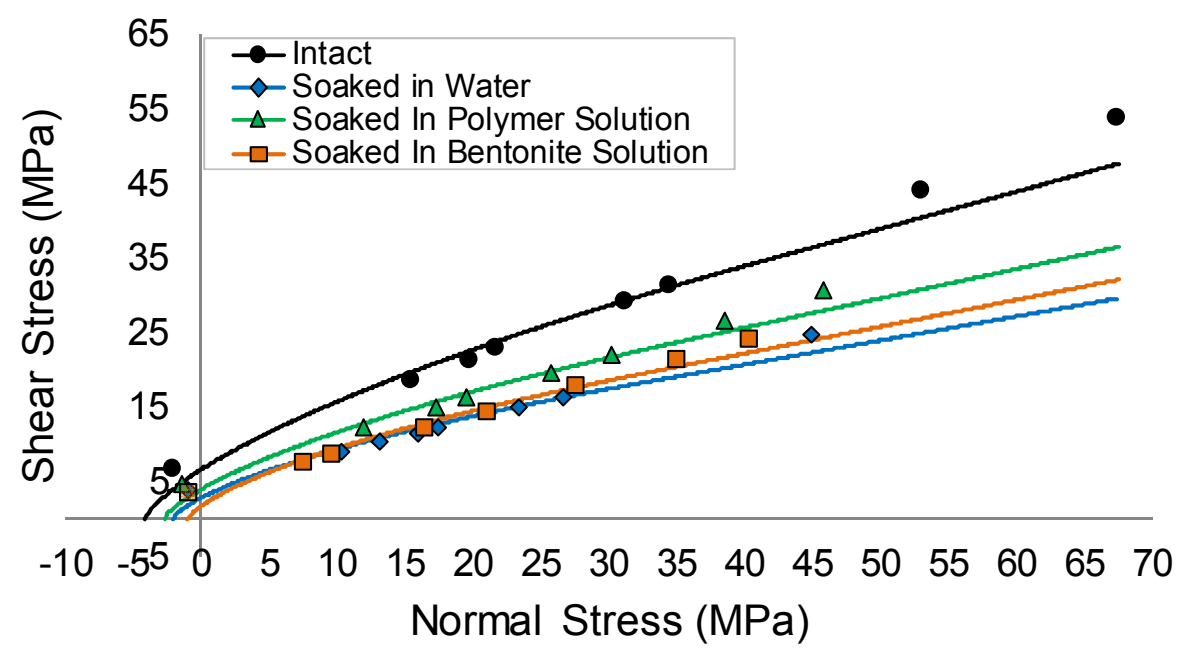

Fig. 13. Strength envelopes of MQS (Intact and after soaking in water, polymer solution and bentonite solution): a) and b) Principal stresses in vertical and horizontal direction, respectively, c) and d) Normal and shear stresses in vertical and horizontal direction, respectively. 